Universidade de São Paulo

Faculdade de Filosofia, Letras e Ciências Humanas

Departamento de Sociologia

\title{
Participação popular em Belém A experiência do Congresso da Cidade e do Orçamento \\ Participativo e a sociabilidade política brasileira
}

\author{
Joana da Silva Barros
}

Orientador

Prof. Dr. Francisco de Oliveira 
Universidade de São Paulo

Faculdade de Filosofia, Letras e Ciências Humanas

Departamento de Sociologia

\section{Participação popular em Belém A experiência do Congresso da Cidade e do Orçamento \\ Participativo e a sociabilidade política brasileira}

\section{Joana da Silva Barros}

Tese apresentada ao Programa de Pós-Graduação em Sociologia do Departamento de Sociologia da Faculdade de Filosofia, Letras e Ciências Humanas da Universidade de São Paulo, para obtenção de título de Doutor em Sociologia

Orientador

Prof. Dr. Francisco de Oliveira

São Paulo, maio de 2012 
Autorizo a reprodução e divulgação total ou parcial deste trabalho, por qualquer meio convencional ou eletrônico, para fins de estudo e pesquisa, desde que citada a fonte.

Catalogação na Publicaçãa

Serviço de Biblioteca e Documentação

Faculdade de Filosofia, Letras e Ciências Humanas da Universidade de São Paulo

B277p

Barros, Joana da Silva

Participaçio popular em Belem - A experiencia do Congreaso da Cidade e do Orçamento Participativo e a mociabilidade politica bramileira / Joana da Silva Barros ; orientador Franciaco de Oliveira. - Săo Paulo, 2012

$172 \mathrm{E}$.

Tene (Doutorado) - Faculdade de Filonofia, Letran e Ciencias Humsnas da Univeraidade de Säo Paulo. Departamento de Sociologia. Área de concentraçäo: Sociologia.

1. Belem (PA). 2. Participação politica. 3. Orçamento Participativo. 4. Sociologia politica. 5. Movimenton mociaie. I. Oliveira, Prancienco de , orient. II. Titulo. 


\section{Sumário}

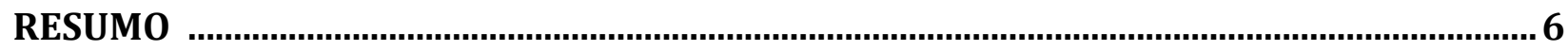

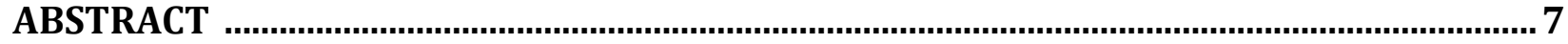

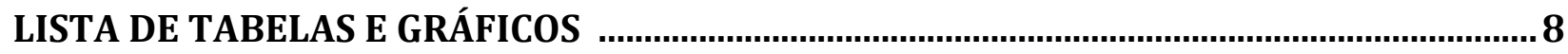

AGRADECIMENTOS

INTRODUÇÃO | Uma pesquisa e suas questões ............................................................ 11

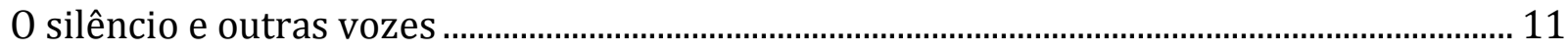

O percurso de constituição do campo de pesquisa ........................................................................ 14

CAPÍTULO 1 | Urbano e rural na Amazônia e em Belém .................................................... 22

Cidade e campo, um debate sobre urbano e rural na Amazônia .............................................. 22

Amazônia, floresta intocada e desabitada: a construção de uma imagem e a ocupação

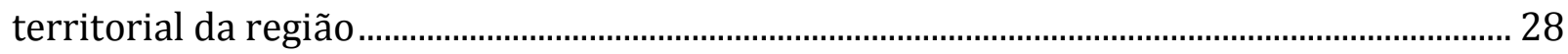

Luzes na floresta: os sujeitos da Pan-Amazônia ............................................................................ 37

CAPÍTULO 2 | Belém: o rio, a floresta, a cidade e seus povos - uma história em disputa

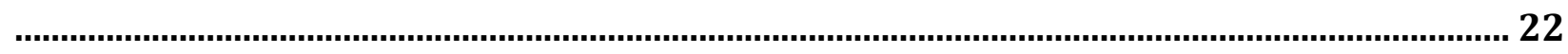

Cidade em disputa: os movimentos sociais em Belém ........................................................... 52

Eleições 1996: história subterrânea ou raio em céu azul? ......................................................... 56

CAPÍTULO 3 | 0 Orçamento Participativo em Belém (1997-2000) ................................. 61

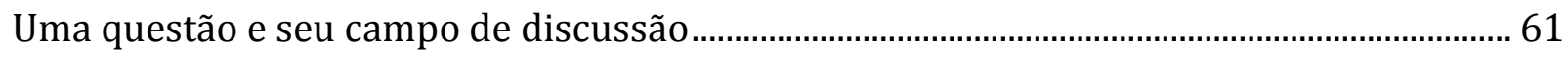

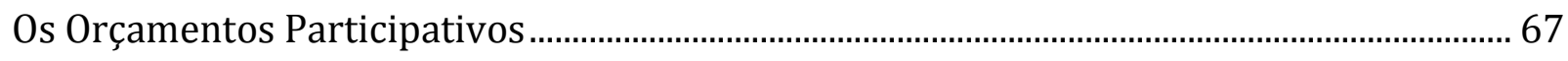

O Orçamento Participativo em Belém (1997-2000): O primeiro mecanismo de participação popular e seus desdobramentos ............................................................................. 72

Estrutura e funcionamento do OP, algumas questões .................................................................. 77

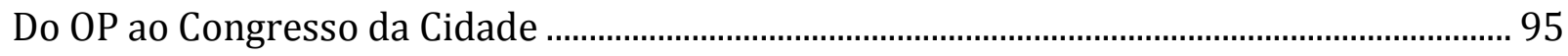


CAPÍTULO 4 | 0 Congresso da Cidade em Belém (2001-2004)......................................100

Qual a aposta política expressa no Congresso da Cidade? Como se aposta?

A aposta em ato: o funcionamento do Congresso da Cidade, algumas questões e seus

limites.

O que Belém fala sobre o Brasil.

CONSIDERAÇõES FINAIS | Olhar o Brasil desde Belém

Subjetivação política: o fio de uma pesquisa ..........................................................................141

Desigualdade na sociabilidade política brasileira: outra ponta do fio ..................................146

Um fio, duas pontas e o nó …………………………………………………………………...156

REFERÊNCIAS BIBLIOGRÁFICAS …............................................................................159 


\section{Resumo}

Esta tese reconstitui a experiência de participação popular ocorrida em Belém do Pará, durante os anos 1997-2004, através de dois mecanismos de gestão pública, a saber, o Orçamento Participativo (1997-2000), dedicado prioritariamente à discussão do orçamento municipal, e o Congresso da Cidade (2001-2004), uma forma mais abrangente de planejamento participativo que pretendia discutir não só o orçamento, mas também as políticas públicas de Belém. Argumenta-se aqui que essa experiência de gestão pública belenense apresenta singularidades em relação à história recente das experiências participativas brasileiras, tanto no que diz respeito à proposta política que a embasou quanto ao desenho e ao mecanismo político que ela introduziu na cidade. Procurara-se demonstrar como, ao trazer para o centro do debate expressões culturais e formas de organização de grupos e povos que durante a constituição de Belém (e quiçá do Brasil) estiveram à margem de seu processo de decisão política, a cidade, a memória e a cultura desses grupos e setores populares - elementos potencializadores e desveladores dos conflitos e disputas políticas que se entretecem na cidade e pelos sentidos desta - tiveram papel fundamental na elaboração política que ali se estabeleceu. Os temas e questões propostos no Congresso da Cidade revelam as tensões vividas nos anos 1990, entre o processo de democratização do Estado brasileiro, caudatário das lutas e movimentos dos anos 1980, e a reconfiguração da economia brasileira que transformou a ação estatal no que concerne às políticas públicas e sociais. A partir da análise do Congresso da Cidade - da experiência política que fomentou e dos grupos, movimentos e sujeitos que ele articulou -, argumenta-se ser possível interrogar as formas de sociabilidade política brasileira e, especialmente, a maneira como a contribuição popular e seu papel político são lidos na formação social brasileira.

Palavras-chave: Belém (PA), Participação popular, Orçamento Participativo, Congresso da Cidade, Gestão democrática.

Email: joana.jsb@gmail.com | joanabarros@usp.br 


\section{Abstract}

This thesis portrays an experience with people's participation in Belém, Pará, during the period from 1997-2004, through two forms of public administration structured around the Participatory Budget (1997-2000), focused mainly on debating the municipal budget, and the City Congress (2001-2004), which became a broader form of participatory planning that discussed both the city's budget and its public policies. We argue that, compared to other recent participatory experiences in Brazil, this one had singularities related to the city's own configuration and to underlying political intentions. The new design and the political mechanisms introduced in Belém sought to focus public debate on cultural expressions and organizational approaches for groups and sectors of the people who had been left out of decision making during the constitution of Belém (and perhaps of Brazil). To that end, the city and the groups' and sectors' memory and culture played a fundamental role in the policy-making process that emerged, as they intensified and highlighted political conflicts and disputes long interwoven into the city and its meanings. The themes and issues raised at the City Congress revealed tensions prevailing in the 1990s, between Brazil's overall process of democratization, coming out of struggles and movements through the 1980s, and the reconfiguration of its economy, which redefined the role of the state vis-à-vis public and social policies. Our analysis of the City Congress, of the political experience it provided and of the groups, movements and players it mobilized sheds light on issues such as forms of political sociability in Brazil and, particularly, how the contribution and the political role of people's movements are interpreted as part of Brazil's social formation.

Key words: Belém (PA), people's participation, participatory budget, City Congress, democratic administration

Email: joana.jsb@gmail.com | joanabarros@usp.br 


\section{Lista de tabelas e gráficos}

Tabela 1 - População total entre 1872 e 2010 ........................................................................... 23

Tabela 2 - População Total, Urbana e Rural entre 1960 e 2010 ............................................... 23

Tabela 3 - Distribuição dos municípios e da população segundo faixas populacionais,

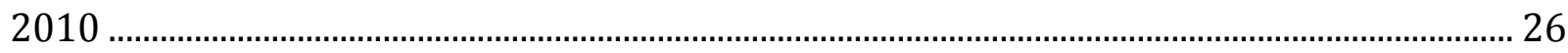

Tabela 4 - Evolução da população total da Região Metropolitana de Belém, 1991, 1996,

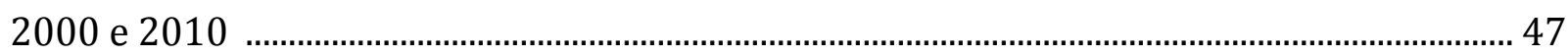

Tabela 5 - Distribuição do Orçamento Participativo por Região, 1997-2000 ………………. 71

Tabela 6 - Proporção do orçamento global deliberada no OP (1997-2000)........................... 88

Tabela 7 - Proporção dos Investimentos deliberada no OP (1997-2000) ................................ 89

Grafico 1 - Evolução da receita própria do município de Belém, 1996-2003......................118

Tabela 8 - Evolução da participação da população nas instâncias do Orçamento

Participativo e do Congresso da Cidade (1997-2004)..............................................................124 


\section{Agradecimentos}

Esta tese foi feita e escrita entre muitas idas e vindas, alguns nascimentos e outras mortes, e uma mudança. Foi marcada por uma sensação de travessia constante, entre três cidades, entre vários assuntos e universos diferentes de interlocutores. Travessia. E como toda travessia ela é devedora de quem fica, de quem nos acompanha e de quem nos recebe por onde se anda.

Ao Chico, meu orientador, agradeço por ter me recebido na "aldeia dos gauleses" e, sentados em volta da mesma mesa, pelo diálogo franco e generoso durante todos estes anos. É um privilégio ver e aprender com sua paixão (como em Gramsci) e rigor intelectual que reconhece no mundo e na vida dos oprimidos a urgência (como em Benjamim) do pensamento crítico como arma para sua transformação. E pelas conversas e histórias deliciosas e coloridas que ouvi.

A Maria Célia com quem aprendi a ouvir, e por seu compromisso com o mundo entre os homens, pela liberdade que pauta sua relação com seus orientandos, convencida que só o pensamento e a palavra nascidos neste diálogo são capazes de alcançar e humanizar o mundo. Pela gentil e leve convivência.

A Cibele que me acompanha desde a entrada no mestrado, pela interlocução comprometida e atenta, por seu compromisso diário e apaixonado com a universidade, o ensino, a formação e o pensamento que transforma o mundo. E pelo convívio afetuoso.

Agradeço imensamente aos meus interlocutores em Belém por me receberam e compartilharam comigo suas histórias e suas apostas, seus julgamentos e sua experiência. Através de suas falas me aproximei de uma cidade viva, que pulsa e que está em constante disputa.

A Marinor, amiga querida, que me recebeu em sua casa e na sua família de forma solidária e generosa, que não sei se poderei um dia retribuir. Obrigada pela acolhida (a mim e aos meus meninos), pelos sorvetes e pelos chorinhos no Gilson, pela conversa sem reservas e pela alegria dos reencontros. Ao Otávio que me levou pra caminhar pela cidade e por me contar histórias vividas por tantos outros cabanos como ele. Ao Luiz Arnaldo pelas conversas em Belém, em São Paulo e no Rio, sempre apaixonantes e encarnadas que 
abriram meus ouvidos e olhos para a floresta. A dona Deusa que me recebeu de forma tão gentil e com tantas comidas gostosas. Ao Edmilson e a Lucília que, além de me franquearem acesso a documentos e material sobre a sua experiência em Belém, foram generosos e solidários em minhas estadas na cidade; e pela convivência camarada em São Paulo.

A Claudio, Chico, Dimitri, Carol, Michelle, Bubble, Laura e Rodrigo, amigos queridos que conviveram com esta tese no meio de tantas outras coisas da vida, nas conversas na mesa da cozinha, embolada no dia-a-dia, junto com meninos nascendo e crescendo, que torceram e por "simplesmente" estarem por perto neste caminhar. À Anna, pelo reencontro; a Caio, André, Andrea, Maria Rita e Nunes pela parceria e convivência na Peabiru que alimentou por outras vias esta tese; ao Lucas pela amizade recente e conversas animadas; ao Marcio pela amizade franca e por não levar a sério minhas sandices; a Joana que me sacudiu quando eu precisei e me fiz rir das minhas doidices; à Ana Claudia pela convivência afetuosa e alegre que me tornaram mais leve neste caminho.

A Dalila, pela revisão atenta e cuidadosa que virou uma conversa sobre o texto. Ao Carlinho, pela disposição de um verdadeiro pesquisador ao me entregar documentos importantes para consolidação desta pesquisa. Aos Embuscados Diego, Tatiana, Mariana, Fábio e Guilherme pela leitura coletiva do Rancière.

Ao Darlan e Luisa, que nos acolheram na chegada ao Rio e que tornaram o turbilhão da mudança mais tranquilo. A Meli, Lívia e Julianna pela convivência alegre e fraterna, que saltou pra vida. Ao Aercio e Evanildo que leram partes do texto, pela solidariedade no convívio diário. Aos colegas da Fase, pela compreensão com que me acolheram com uma tese em escritura.

A Verô pela ajuda solidária e por todo cuidado comigo e com os meninos pra que eu pudesse escrever. Ao Ray pela torcida, solidariedade e ajuda, em especial neste finalzinho de escritura da tese. A Rita e Julia, minhas irmãs queridas, presentes de formas diferentes nesta tese, pelo apoio incondicional a este projeto de vida tão tortuoso que sigo. A Duda, João, Bernardo e Thiago, meus sobrinhos que nasceram no meio de tudo isto e alegram nossas vidas. A dona Rosa e Márcia, que cuidaram dos meninos enquanto eu estive em Belém.

Ao Raul e Francisco, agradeço, mais do que consigo dizer, pela alegria e vivacidade com que pularam pra dentro da minha vida, pelo amor que disto brotou e por terem reclamado para que eu acabasse logo esta "chatice de livro". Ao Gabriel que atravessou mais uma tese e ficou feliz quando finalmente acabou.

Ao Edson, meu amor, que compartilha comigo as esperanças e sonhos de um mundo livre e fraterno, que constrói uma vida que não se encerra nos limites do privado e que sabe que a trajetória condensada nesta tese é parte desta aposta. Obrigado por não me deixar desistir, pela leitura atenta e generosa e, sobretudo, por me fazer feliz e rir comigo!

Esta pesquisa contou com o CNPq através de uma bolsa de estudos por 36 meses. 
A memória, todos nós sabemos, é o combustível que nos faz luz e amanhã.

Subcomandante insurgente Marcos Mensagem ao II Encontro Americano pela Humanidade e contra o neoliberalismo

Belém, 1999 
introdução

\section{Uma pesquisa e suas questões}

Conta Luiz Arnaldo ${ }^{1}$ que decidiu mudar-se para o Pará um dia viajando pelo estado para acompanhar uma atividade de sua organização política, num ônibus típico do interior do Brasil: cheio de pessoas, parando em todos os cantos, o que faz a viagem aparentemente curta levar o dobro do tempo. Estrada ruim, pessoas com pequenos animais vivos dentro do ônibus, muitas crianças, malas e farnéis para enfrentar o caminho, muita conversa e alguma agitação. Numa parada do ônibus, entra um garoto, cesta numa mão e um pequeno bolinho recheado na outra, aguando a boca dos passageiros. "Quem quer sonho...? Quem quer sonhar...?" gritava o menino. E seu grito pareceu um convite esperançoso e alegre, em meio a uma Amazônia desconhecida no coração do Brasil. Luiz Arnaldo mudou-se para Belém e participou, alguns anos depois, do autointitulado Governo do Povo.

Tão longe, tão perto.

\section{O silêncio e outras vozes}

"Você é de Belém...?". Esta é a primeira pergunta que me fazem quando falo sobre meu "objeto" de estudo de doutorado. Um misto de espanto e desconhecimento, um pouco de surpresa e uma nota de expectativa pelo suposto "exotismo" do lugar, muitas vezes aparecem na expressão e nas observações dos interlocutores, dentro e fora da universidade. Espanto que a minha resposta negativa tende a reforçar.

\footnotetext{
${ }^{1}$ Luiz Arnaldo Campos é cineasta, foi Coordenador de Relações Internacionais do município de Belém, na gestão Edmilson Rodrigues e um dos elaboradores da recuperação da tradição de luta popular expressa na Cabanagem.
} 
No que concerne ao objeto desta tese, esse espanto revela a ausência de um lugar para estudos sobre experiências políticas dessa natureza, estudos que não estejam marcados por uma visão desde o "sul maravilha" - como dizia a lendária personagem Graúna do cartunista Henfil -, que torna exótico ou folcloriza aquilo que não é seu espelho. Por que estudar Belém do Pará? Por que estudar algo tão circunscrito a um período de tempo? Qual o interesse disto para "a" sociologia? Qual a pertinência de um estudo deste tipo no conjunto da produção sobre participação popular na gestão pública? Belém fala do Brasil? Estas são algumas das indagações que surgem no contato com o tema desta pesquisa e, mais que isto, a auxiliam a se posicionar no debate, não como um estudo regional que se dirige ao centro, mas como uma leitura feita por um olhar que se desloca para alcançar uma perspectiva ampliada do país, que de outra forma continuaria obscurecida.

Por outro lado, olhando em direção ao próprio conteúdo da experiência de Belém, é avista-se outra questão: é possível uma experiência política numa cidade que, grosso modo, podemos concordar, não está no centro econômico dinâmico do Brasil? Esta certamente é uma questão que me persegue e é perseguida por mim neste trabalho.

A literatura consagrada sobre participação popular na gestão pública ou sobre os mecanismos de participação pública, em especial nos polos universitários que notadamente se debruçam sobre o tema, pouco espaço têm dedicado a essa experiência em Belém. Mesmo se consideramos a produção dispersa nos centros e programas de pós-graduação espalhados pelo Brasil, apenas na Universidade Federal do Pará há uma produção acadêmica significativa do ponto de vista numérico sobre os mecanismos de participação popular que aconteceram em Belém.

Para além de um reclamo, esse silêncio na literatura me chamou atenção. Conhecia a experiência participação popular em Belém por canais não acadêmicos e, de São Paulo, acompanhei a gestão no município de Belém entre 2001-2004 que coincidiu com o meu mestrado neste Departamento sobre população de rua (outro tema silenciado, dentro e fora dos muros da USP), mas não a via relatada ou analisada nos trabalhos sobre esse campo. Mesmo na pesquisa que o Cenedic realizou sobre o OP em São Paulo², da qual participei, a referência entre os pesquisadores e na bibliografia mobilizada, assim como no imaginário

\footnotetext{
${ }^{2}$ Uma parte dos textos resultantes desta pesquisa está acessível no livro organizado por Francisco de Oliveira e Cibele Rizek (2007). Ver especialmente para este tema os artigos de Carlos Alberto Bello e Cibele Rizek.
} 
dos interlocutores que entrevistamos - agentes sociais engajados na discussão sobre orçamentos participativos -, a experiência de participação popular em Belém era uma imagem distante e sem muita consistência. 0 contraponto imediato a essa imagem fugidia era e continua a ser a referência à Porto Alegre, que em muitos momentos é tomada como experiência paradigmática e exemplo prático a ser seguido, ou ainda a de Belo Horizonte, outro polo importante de acúmulo dos movimentos sociais e experiência municipal de participação na gestão pública.

Esse silenciamento na literatura abre duas vertentes de pesquisa que eu pretendo cruzar nesta tese. Por um lado, a discussão do instrumento de democratização da gestão das cidades e que, portanto, deve dialogar com parte substantiva (e hegemônica) da produção acadêmica da tanto da sociologia política, que se debruça sobre a história brasileira recente, quanto da ciência política, que vem discutindo os mecanismos institucionais concernidos nesse processo, infelizmente num registro cada vez mais normativo e procedimentalista. E por outra via, um tanto mais tortuosa e certamente menos explorada, a inserção deste debate sobre a participação política dos pobres e trabalhadores na fortuna crítica da história dos trabalhadores no Brasil, tentando estabelecer um diálogo com os estudos daquilo que se consolidou como uma área de conhecimento na sociologia e na ciência política nomeada como "pensamento social e político brasileiro".

Este não comparecimento de Belém ao debate sobre a participação popular no Brasil abre uma possibilidade de interrogação sobre a figuração dos pobres e trabalhadores no conjunto da produção acadêmica. Em certa medida, este é o interesse que dá suporte e estrutura a esta pesquisa e às preocupações que ela enfrenta. De forma muito resumida, está no meu horizonte de questões a discussão sobre como uma dada figuração dos pobres e dos trabalhadores incide na maneira como se lê a sua participação e ação política. A reconstituição de um processo de participação popular fora do Centro-sul brasileiro parece um observatório significativo e um lugar privilegiado a partir do qual estabelecer um diálogo com esses estudos. Diálogo sempre tenso e, em certa medida, por fora da produção consagrada na universidade.

0 fio condutor das análises empreendidas nesta tese refere-se às discussões propostas por Jaques Rancière e a compreensão da política como um ato de subjetivação política, como conflito, como dissenso. 
[...] a política existe ali onde a contagem das parcelas e das partes da sociedade é perturbada pela inscrição dos sem-parcela. Ela começa quando a igualdade de qualquer um com qualquer um inscreve-se como liberdade do povo. Essa liberdade do povo é uma propriedade vazia, uma propriedade imprópria pela qual aqueles que não são nada colocam seu coletivo como idêntico ao todo da comunidade. A política existe enquanto formas de subjetivação singulares renovarem as formas de inscrição primária da identidade entre o todo da comunidade e o nada que a separa de si mesma, quer dizer, da contagem apenas de suas partes (Rancière, 1996: 123).

Esta perspectiva de análise do Congresso da Cidade e do Orçamento Participativo em Belém distancia-se da embocadura dos trabalhos de análise dos OPs a partir de seu funcionamento interno e suas formas de institucionalização. Não se trata de menosprezar ou negar tais dimensões, mas de recolocá-las no debate sobre participação popular, percebendo-os não apenas como instrumentos ou formas institucionais de democratização e sim, como experiência pública de subjetivação política (nos termos de Rancière). Momentos a partir dos quais - esta é a tese principal deste trabalho - é possível reconsiderar alguns aspectos da história política do Brasil e interrogar as suas dimensões democratizantes e suas interdições, situando-os no conjunto da formação brasileira, bem como perceber as singularidades da Amazônia compreendida dentro do território do país e por que não, da Amazônia urbana.

Sendo assim, esta tese pretende reconstituir e discutir a experiência de participação popular ocorrida em Belém do Pará, durante os anos 1997-2004, que se estruturou a partir do Orçamento Participativo (1997-2000) e, posteriormente, do Congresso da Cidade (20012004) e compreender o que Belém fala sobre as formas de sociabilidade política brasileira.

\section{0 percurso de constituição do campo de pesquisa}

Este texto está marcado por várias dimensões que o compuseram. Algumas delas particulares e não públicas, por assim dizer, mas que compõem sua (minha...) história; algumas outras por dimensões políticas de natureza não acadêmica que em certa medida, 
pressionam as disposições e percursos seguidos em campo. E outras escolhas e um percurso acadêmico da qual esta tese é parte e também motor.

Das disposições "não acadêmicas" que constituem esta tese é importante dizer que minha relação com a cidade e com o tema que escolhi para debater extrapola os muros da universidade. Conheço esta administração de Belém antes de virar meu tema de pesquisa e muitas pessoas que se tornaram ou já eram meus amigos estiveram envolvidos na sua gestão. Digo isto por dois motivos: o primeiro é antes de tudo um agradecimento (meio deslocado), e o segundo que decorre deste é porque sem esta rede de interlocutores e amigos não seria possível acessar uma parte significativa dos documentos e informações que juntei nestes anos de pesquisa.

Durante o período que estudo nesta tese, de 1997 a 2004, a Secretaria Municipal de Coordenação Geral e Planejamento (SEGEP) ficou responsável pela guarda e arquivamento dos documentos relativos ao Orçamento Participativo e ao Congresso da Cidade. 0 material recolhido durante os oito anos da administração que estava sob guarda da SEGEP, foi catalogado e colocado à disposição do público, com uma estrutura de funcionamento para pesquisa e consulta. Após a posse do novo prefeito da cidade Dulciomar Costa (PTB), em 2005, essa biblioteca passou por diversos reveses, de enchentes a assalto ao prédio onde estava abrigada. A cada evento a biblioteca ao invés de ser reconstituída e melhorada, perdia espaço, ficava com seus documentos molhados ou sem os equipamentos roubados e assim foi até o acervo ser trancado numa sala da SEGEP, fora do prédio onde funciona a biblioteca e os outros departamentos dessa secretaria, sem que a bibliotecária ou mesmo o público tivesse acesso a ele. Assim, não fosse por esta rede de interlocutores e amigos, esta pesquisa praticamente não existiria. 0 material que coletei vem de arquivos pessoais dos entrevistados que, generosamente, além de me contarem sua experiência e partilhar suas impressões sobre aquele governo, doaram parte de sua memória materializada em folhetos, cadernos de teses, documentos internos à administração, livros e publicações diversas e, assim, possibilitaram que eu me aproximasse desse período. Não há outra maneira de nomear essa disposição que pude experimentar em campo, senão como amizade, tal como os gregos a concebiam, como aquilo que sustentado pelo discurso fundamenta a vida pública, fundamenta a política. Hannah Arendt toma essa formulação dos gregos, de 
Aristóteles especificamente, e acentua a importância e os vínculos entre amizade, discurso e humanização:

Mas, para os gregos, a essência da amizade consistia no discurso. Sustentavam que apenas o intercâmbio constante de conversas unia os cidadãos numa pólis. No discurso, tornavam-se manifestas a importância política da amizade e a qualidade humana própria dela. Essa conversa (em contraste com a conversa íntima onde os indivíduos falam sobre si mesmos), ainda que talvez permeada pelo prazer com a presença do amigo, refere-se ao mundo comum, que se mantém "inumano" num sentido muito literal, a menos que seja constantemente comentado por seres humanos. Pois o mundo não é humano simplesmente por ser feito por seres humanos, e nem se torna humano simplesmente porque a voz humana nele ressoa, mas apenas quando se torna objeto de discurso. Por mais afetados que sejamos pelas coisas do mundo, por mais profundamente que possam nos instigar e estimular, só se tornam humanas para nós quando podemos discuti-las com nossos companheiros. Tudo o que não possa se converter em objeto de discurso - o realmente sublime, o realmente horrível ou misterioso - pode encontrar uma voz humana com a qual ressoe no mundo, mas não é exatamente humano. Humanizamos o que ocorre no mundo e em nós mesmos apenas ao falar disso, e no curso da fala aprendemos a ser humanos.

Os gregos chamavam essa qualidade humana que se realiza no discurso da amizade de philantropia, "amor dos homens", pois se manifesta numa presteza em partilhar o mundo com outros homens (Arendt, 1987: 31 [grifos no original]).

Através de carta deste Departamento de Sociologia, tentei contato com a SEGEP buscando acessar o arquivo, onde deveria encontrar as pesquisas feitas durante os anos do OP e Congresso da Cidade, com perfil de população participante, listas de demandas, os folhetos e textos base para discussão nas plenárias... enfim, material primário que seria útil para consolidação desta tese. Infelizmente, apesar das tentativas formais e informais, não foi possível acessar o material. 0 material sobre o Congresso da Cidade que tive acesso na biblioteca da SEGEP está bastante fragmentado, e foi coletado por iniciativa individual e 
valorosa da bibliotecária Marly Brito, que, desde o fechamento do arquivo, vem reunindo material impresso e digital sobre o período e catalogando-o. Somente no começo do ano de 2012 a biblioteca da SEGEP foi reaberta ao público. É preciso registrar que tive acesso a um acervo grande de documentos digitalizados que me foram fornecidos por José Carlos Matos Pereira, que trabalhou na SEGEP, outra fonte importante e fundamental para este trabalho.

Essa dificuldade de pesquisa revela mais do que as dificuldades que todo pesquisador enfrenta em campo. Revela a forma como a história é tratada pelo Estado, num esforço sistemático de apagar as marcas do passado; neste caso específico, as marcas e a esperança presentes em um período e numa experiência que é substantivamente diferente da regra geral de dominação que Belém viveu e vive - ou melhor, vivemos nós.

Importa ainda dizer algo sobre as disposições não acadêmicas que incidem grandemente sobre as acadêmicas neste trabalho. Este é claramente político no sentido em que há uma disposição em filiar-se a uma determinada tradição sociológica que percebe (e realiza) a necessidade de comprometimento da universidade com a sociedade à sua volta, acolhendo assim as dimensões públicas e politizantes na sua prática e reflexão. Isto não significa, entretanto, que penso a universidade como um lugar de panfletos; mas me parece deve ser lugar de crítica e compromisso com a mudança social. Essa disposição pessoal incide sobre os autores e referências teóricas que escolhi para ver e analisar a experiência em Belém, e, neste sentido, as referências aqui mobilizadas afastam-se da média dos trabalhos que compõem o campo no qual o assunto desta pesquisa comumente está inserido, ainda que seja preciso tratar e dialogar com elas ao longo da tese.

$\mathrm{Na}$ escolha por tratar este tema a partir das entrevistas e falas dos interlocutores e informantes que fui ao longo da pesquisa amealhando, anima-me a ideia de que a experiência de participação popular em Belém registrada nesta tese é obra do esforço de milhares de pessoas que participaram dela, que, ao se dispor a discutir sua vida para além dos limites da sua intimidade ou particularidade, fizeram sua ação individual conectar-se ao fluxo da história, dando voz a suas formas de ver o mundo, construindo conflitivamente uma cena pública a partir de onde falam, politizando, assim, sua condição.

As entrevistas coletadas e as falas dos interlocutores são assim obra de memória, é palavra que resgata do esquecimento e da solidão a experiência vivida, a história de si e dos outros e confere sentido ao passado no presente - portanto, sempre móvel e em construção. 
Uma leitora atenta de Walter Benjamin, Jeanne Marie Gagnebin, é quem condessa em texto este esforço que pretensamente me aventuro a fazer:

A palavra rememorativa ${ }^{3}$, certamente imprescindível, não tira sua força mais viva da conservação do passado e da perseverança de escritores, historiadores ou filósofos; mas do apelo à felicidade do presente, isto é, em termos filosóficos antigos, da exigência da vida justa dos homens junto a outros homens. Ouvir este apelo do passado significa também estar atento a esse apelo de felicidade e, portanto, de transformação do presente, mesmo quando ele parece estar sufocado e ressoar de maneira quase inaudível (Gagbenin, 2006: 12).

O trabalho de pesquisa sobre a experiência de participação popular na administração municipal em Belém começou no ano de 2005. Naquele momento, um ano após a derrota eleitoral do governo de Edmilson Rodrigues que não conseguiu fazer sua sucessora Ana Julia Carepa ${ }^{4}$, o material que pude acessar foram publicações nas quais a gestão municipal fizera para análise e divulgação dos seus mandatos. Material bastante marcado e datado, certamente, mas que me permitiu tomar contato com a formulação publicizada sobre o Congresso da Cidade e o OP e, mais largamente, com as formas de participação popular experimentadas no período. Naquele momento, a questão que mais fortemente marca meus textos - relendo-os hoje - era a interrogação sobre a não continuidade da experiência de participação em Belém; o meu universo de preocupações ligava-se ali às razões pelas quais o autointitulado "Governo Cabano" não havia se reeleito. 0 que estava por trás desta preocupação - vendo em retrospectiva - parece ser uma pergunta bastante simples (meio ingênua, talvez) sobre as razões que levam um conjunto de pessoas a não continuarem apostando na construção de uma alternativa, se não emancipadora, ao menos mais democrática para sua cidade. Sinteticamente, perguntavam-me: qual o enraizamento real

\footnotetext{
${ }^{3}$ Jeanne Marie Gagnebin refere-se à autocomplacência erudita que percebe seu trabalho de sedimentação da memória como um fim em si mesmo, criticando esta prática - tão comum na Universidade, me parece - a partir de Benjamin e de Nietzsche, referências paradoxais, segundo a autora (Gagnebin, 2006: 11-12).

4 Posteriormente, Ana Julia Carepa foi eleita governadora do Pará em 2006, pelo Partido dos Trabalhadores, em ampla aliança ao centro, inclusive com apoio do grupo político de Jader Barbalho.
} 
dessa experiência, se ela não faz sua sucessão? Naquele momento, o discurso da administração sobre o período era tão potente que me conduziu a uma gama de preocupações muito mais referidas ao campo da própria gestão que se encerrava e menos para as questões que ela abria em diálogo com outras dimensões.

Os anos seguintes, até a minha entrada no programa em 2007 para o ano letivo de 2008, as preocupações que me mobilizaram foram se deslocando do Congresso da Cidade em si e se assentando naquilo que saltava aos olhos: as peculiaridades de Belém e desta sua experiência. 0 projeto inicialmente debruçava-se somente sobre o Congresso da Cidade, recortando o período de 2001 a 2004, e já em certa medida admitia que este houvesse sido superior qualitativamente ao OP. O que estava obscurecido era justamente a relação do OP com o Congresso. Mais do que uma passagem, tal qual eu a compreendia naquele momento, o Congresso guardava relações mais profundas com o OP: sua filiação a uma mesma elaboração política sobre o papel dos mecanismos de gestão pública; o fato do Congresso da Cidade ter mantido na sua estrutura uma forma de participação do OP, como o Orçamento da Juventude, além, evidentemente, de serem dois momentos da mesma administração. Essa relação, entretanto, só se mostrou uma questão de pesquisa ao longo do campo.

A mudança de embocadura do projeto determinou alterações na constituição da rede de informantes e do tipo de aproximação que fiz com as pessoas entrevistadas. A montagem da rede procurou cobrir, então, os diversos setores que participaram do Congresso segundo os setoriais e temas a partir do qual ingressaram neste espaço, buscando abordar temas sensíveis para esta tese, como a participação dos setores e/ou grupos que até então não tinham incidência em outros mecanismos de participação, a exemplo dos indígenas e homossexuais. Os vários segmentos foram contatados: vereadores de situação e oposição, secretários e assessores, pessoas com destacado papel político no governo municipal, assim como seus críticos, uma gama de pessoas capazes de refletir a diversidade de questões envolvidas no processo de gestão municipal. Agreguei ainda ao conjunto de entrevistas, participantes do OP bem como seus coordenadores junto à administração municipal.

A organização formal da tese procura dar conta de alguns nexos e perguntas que guiaram a pesquisa. No capítulo 1, Urbano e rural na Amazônia e em Belém, proponho uma leitura das figurações da Amazônia como espaço vazio, de cidades (quantitativamente falando) e de sujeitos políticos, atados a um lugar de espera e impossibilidade. 0 esforço 
aqui é no sentido de desnaturalizar os lugares consolidados a partir de onde se observa e se lê o que ali se passa. Essa perspectiva conecta o que se deu em Belém com os processos amazônicos e, ao desnaturalizar a Amazônia, permite que consideremos Belém desde seus pressupostos, mas construídos e considerados também na dinâmica nacional.

No capítulo 2, dedico-me a explorar a constituição de Belém e sua formação social e política, considerando as disputas envolvidas neste processo como formas de construção de sentidos para a experiência social. Aqui argumento que as lentes de leitura dicotômica não nos ajudam a compreender uma cidade que está na porta da Amazônia e, portanto, referida a um conjunto de questões que lhe impactam, mas acontecem fora de seus limites geográficos, e que é constituída na tensão lida (pela tradição do pensamento brasileiro) como a contradição em ato entre atraso e moderno. Ainda nesse capítulo abordo a constituição da cena política que sustentou por oito anos a gestão de Edmilson Rodrigues na prefeitura de Belém.

No capítulo 3 analiso a construção e funcionamento do Orçamento Participativo em Belém, suas premissas, sua forma de funcionamento e seus impasses. O OP foi sucedido pelo Congresso da Cidade, implantado na segunda gestão entre os anos de 2001 e 2004. Nesse capítulo, avanço na discussão sobre a relação entre os dois mecanismos de gestão pública partilhada e uma vez que diferem sobre a forma e o sentido da participação popular na cidade, procuro estabelecer os vínculos de continuidade e descontinuidade entre eles.

O capítulo 4 é dedicado ao estudo do Congresso da Cidade em Belém. Nele procuro demonstrar como se articulam as questões que tratei nos capítulos anteriores, especialmente aquelas relativas aos sujeitos concernidos nos processos de participação popular, as apostas políticas feitas no período, o papel da cultura como elemento substantivo no processo de subjetivação política que, defendo, teve palco em Belém. 0 foco desse capítulo está em iluminar o que, no conjunto dessa experiência política na cidade, pode falar para além dos seus limites, extrapolando as dimensões municipais e voltando-se para o Brasil.

Por fim, nas considerações finais proponho uma leitura da sociabilidade política brasileira desde as questões levantadas pelo Congresso da Cidade. Para isto, retomo a leitura de Jacques Rancière e Maria Sylvia Carvalho Franco. 
Como se poderá ver ao longo do texto e por esta exposição, os autores e questões teóricas serão tratadas ao longo dos capítulos à medida que seja necessário. Esta é uma tese que propõe e compartilha com o leitor a aventura de construir uma visão sobre Belém desde os processos enraizados na cidade. Pretende ser, assim, um caminho de leitura, posicionada e convencida de que "o real não está na saída nem na chegada: ele se dispõe para a gente é no meio da travessia". 
capítulo 1

\section{Urbano e rural na Amazônia e em Belém}

\section{Cidade e campo, um debate sobre urbano e rural na Amazônia}

Para pensar criticamente o lugar do urbano e, mais especificamente das cidades na Amazônia, é preciso nos desfazer de algumas imagens-força que hegemonizam esse debate. Trata-se de um esforço de desnaturalização dessas imagens - marteladas insistentemente pela mídia e, em certa medida, ratificadas pelo discurso acadêmico - através das quais moldamos a nossa compreensão das cidades (transformadas em a cidade, no singular, sem diversidades e, portanto, conflitos), explicamos suas questões, reconhecemos e legitimamos seus sujeitos. Essas imagens forjaram um vínculo quase indissociável entre urbano e vastos territórios ocupados (ditos "urbanizados"), ou, segundo o léxico acadêmico, entre urbano e metrópole.

Essa desconstrução nada tem de iconoclasta. Trata-se de operar, por dentro dos lugares estabelecidos, um mecanismo de estranhamento e nomeação cujo intento primeiro é provocar um deslocamento entre a coisa e seus sentidos; num esforço de, ao dizer a mesma palavra, expressar significados amortecidos e apagados pelo discurso hegemônico e, assim, disputar uma constelação de sentidos condensados ali.

Belém e Manaus são as duas únicas cidades na Amazônia Legal com população superior a 1 milhão de habitantes, e São Luiz, capital do Maranhão, é a única na faixa imediatamente inferior, ou seja, com população entre 500 mil e 1 milhão de habitantes. Não obstante, a região Norte tem hoje mais de $70 \%$ de sua população morando em cidades, o 
que significa pouco menos de 12,9 milhões de pessoas, em 2000 e pouco mais de 15,8 milhões segundo o último Censo de 2010.

Tabela 1 - População total entre 1872 e 2010

\begin{tabular}{|c|c|c|c|c|c|c|}
\hline & 1872 & 1890 & 1900 & 1920 & 1940 & 1950 \\
\hline Brasil & 9.930 .478 & 14.333 .915 & 17.438 .434 & 30.635 .605 & 41.236 .315 & 51.944 .397 \\
\hline Norte & 332.847 & 476.370 & 695.112 & 1.439 .052 & 1.627 .608 & 2.048 .696 \\
\hline Pará & 275.237 & 328.455 & 445.356 & 983.507 & 944.644 & 1.123 .273 \\
\hline Belém & 61.997 & 50.064 & 96.560 & 236.402 & 206.331 & 254.949 \\
\hline & 1960 & 1970 & 1980 & 1991 & 2000 & 2010 \\
\hline Brasil & 70.992 .343 & 94.508 .583 & 121.150 .573 & 146.917 .459 & 169.590 .693 & 190.755 .799 \\
\hline Norte & 2.930 .005 & 4.188 .313 & 6.767 .249 & 10.257 .266 & 12.893 .561 & 15.864 .454 \\
\hline Pará & 1.550 .935 & 2.197 .072 & 3.507.312 & 5.181 .570 & 6.189 .550 & 7.581 .051 \\
\hline Belém & 402.170 & 642.514 & 949.545 & 1.244 .688 & 1.279 .861 & 1.393 .399 \\
\hline
\end{tabular}

Fonte: IBGE, Séries Estatísticas, 2012.

Tabela 2 - População Total, Urbana e Rural entre 1960 e 2010

\begin{tabular}{|r|rrrrrr|}
\hline & $\mathbf{1 9 6 0}$ & $\mathbf{1 9 7 0}$ & $\mathbf{1 9 8 0}$ & $\mathbf{1 9 9 1}$ & $\mathbf{2 0 0 0}$ & $\mathbf{2 0 1 0}$ \\
\hline Brasil & 70.992 .343 & 94.508 .583 & 121.150 .573 & 146.917 .459 & 169.590 .693 & 190.755 .799 \\
$\quad$ Urbana & 32.004 .817 & 52.904 .744 & 82.013 .375 & 110.875 .826 & 137.953 .959 & 160.925 .792 \\
Rural & 38.987 .526 & 41.603 .839 & 39.137 .198 & 36.041 .633 & 31.845 .211 & 29.830 .007 \\
\hline Norte & 2.930 .005 & 4.188 .313 & 6.767 .249 & 10.257 .266 & 12.893 .561 & 15.864 .454 \\
$\quad$ Urbana & 1.041 .213 & 1.784 .223 & 3.398 .897 & 5.931 .567 & 9.014 .365 & 11.664 .509 \\
$\quad$ Rural & 1.888 .792 & 2.404 .090 & 3.368 .352 & 4.325 .699 & 3.886 .339 & 4.199 .945 \\
\hline Pará & 1.550 .935 & 2.197 .072 & 3.507 .312 & 5.181 .570 & 6.189 .550 & 7.581 .051 \\
$\quad$ Urbana & 630.672 & 1.037 .340 & 1.702 .403 & 2.609 .777 & 4.116 .378 & 5.191 .559 \\
$\quad$ Rural & 920.263 & 1.159 .732 & 1.804 .909 & 2.571 .793 & 2.073 .172 & 2.389 .492 \\
\hline Belém & 402.170 & 633.374 & 933.280 & 1.244 .689 & 1.280 .614 & 1.393 .399 \\
$\quad$ Urbana & & 602.829 & 824.405 & 849.187 & 1.272 .354 & 1.381 .475 \\
$\quad$ Rural & & 30.545 & 108.875 & 395.502 & 8.260 & 11.924 \\
\hline
\end{tabular}

Fonte: IBGE, Séries Estatísticas, 2012.

Esses dados revelam a face urbana da região, o que, em certa medida, pode causar estranhamento devido à diferença entre esta e a imagem tradicional da Amazônia como um território imenso, inexplorado e despovoado, “ainda preso" ao mundo rural, ou melhor para usar a mais recente imagem-síntese da região -, reduto de vida selvagem e natureza 
intocada ${ }^{1}$. A Amazônia como região de incalculáveis riquezas é uma imagem-síntese constantemente reatualizada e parece ser um importante elemento de construção das condições ideológicas de validação social de sua ocupação, bem como dos métodos através dos quais esta se processa.

Ler a dinâmica da Amazônia urbana, da região Norte e, especificamente para esta tese, da cidade de Belém, supõe considerá-la em relação inescapável com o conjunto de cidades (e povoados e aldeias) que formam esta rede de "cidades na floresta"2. Essa rede peculiar é a expressão dos diversos ciclos de desenvolvimento econômico fomentados pelo Estado para a região, que remontam ao período colonial (Castro, 2008). A compreensão da função e da forma das cidades na Amazônia passa pelo reconhecimento de que essa peculiaridade - e não exotismo - está plenamente de acordo com as formas de desenvolvimento econômico nacional ao longo da história e com a ação política e econômica do Estado e dos agentes privados na região.

Para garantir sua presença mesmo nos lugares mais distantes, a colonização portuguesa ocupou o território amazônico através da instalação de pequenos postos fortificados em lugares importantes na geopolítica da época. A colonização orientou-se por uma dupla preocupação: de um lado, com a conquista desse território e, por outro, com a organização dos interesses econômicos metropolitanos na região. Essa dupla orientação estabeleceu as formas da produção extrativista, o meio de transporte de mercadorias pela rede fluvial (como é feito em grande parte até hoje), a relação com os povos indígenas (que através da catequese, da "civilização" e da dominação strito senso foram arregimentados como trabalhadores servis nesse novo sistema que se montava) (Castro, 2008). Assim, as cidades surgem na Amazônia nos rastros da conquista portuguesa do território e da produção econômica colonial, contraposta, desde o primeiro momento, às formas de vida, de ocupação do território e de relação entre a natureza e os habitantes da região.

\footnotetext{
${ }^{1}$ Para dimensionar o papel dos meios de comunicação na produção dessa imagem, é importante considerar as inúmeras reportagens exibidas na televisão aberta sobre a "beleza natural" da Amazônia e sua importância para o Brasil e para o mundo, tais como as veiculadas em programas semanais como Globo Repórter da Rede Globo e na mídia impressa de grande circulação.

2 Esta expressão foi extraída de livro homônimo organizado por Edna Castro, fruto do Seminário Internacional Cidades na Floresta, realizado pelo Núcleo de Altos Estudos Amazônicos da UFPA, no âmbito da pesquisa "Cidades, Povoados e Aldeias: construindo uma tipologia de aglomerados urbanos na Amazônia", que acompanha e discute as dinâmicas urbanas na região (cf. Castro, 2008).
} 
Dessa ocupação inicial nos tempos da colônia até praticamente metade do século XVIII, a região amazônica despertou pouco interesse imediato; permaneceu com baixa ocupação exterior e pouca exploração econômica. Parte da dificuldade de exploração e integração econômica era dada pelas condições geográficas regionais. No final do século XIX, com a reorganização da economia brasileira por meio de uma nascente produção industrial e da reconversão de parte da produção agrária, a Amazônia passará a figurar nos planos de expansão econômica do Estado nacional, e surgirá, com a exploração das seringueiras para extração de látex, como uma região importante para o conjunto da economia brasileira.

O ciclo da borracha (1850-1920) - presente ainda hoje nas cidades de Belém e Manaus através de seus palacetes e teatros da Belle Époque - foi o momento de consolidação de uma rede propriamente urbana na Amazônia, com a formação de novas cidades decorrentes desse fluxo econômico de motivação externa e do consequente adensamento do povoamento da região ${ }^{3}$. Esse ciclo "fez aparecer vilas e povoados que deram origem posteriormente a cidades, fortalecendo algumas delas de forma mais expressiva, como Belém e Manaus" (Castro, 2008: 18), ao mesmo tempo em que consolidou uma rede de cidades portuárias, as quais, ao longo dos rios e igarapés da região, escoavam a produção de borracha. Entretanto apenas nestas duas cidades a atividade portuária destinava-se ao comércio externo, enquanto, na maioria das outras cidades, ela restringiase ao despacho da produção local e não estabelecia maiores efeitos econômicos sobre aquela cidade. Indicativo da hierarquização presente na estruturação e no funcionamento dessa rede, esse dado aponta também para a necessidade de lermos a formação e o perfil populacional e de ocupação territorial da região nos marcos de um quadro amplo e articulado de cidades e da inserção destas na economia regional e nacional.

Uma rápida análise dos dados de população da região Norte em comparação com os números do país mostrará que perfil populacional desta não se afasta muito da média nacional e que esta acompanhou o movimento de urbanização da população brasileira até

\footnotetext{
${ }^{3}$ Muitos autores consagrados se dedicaram à discussão do funcionamento econômico do ciclo da borracha e dos impactos da exploração do látex na estruturação do território amazônico e da arquitetura, do urbanismo e da dinâmica sociocultural nas cidades da região. Além dessa discussão acadêmica, a economia da borracha está presente também na literatura ambientada na região, ver especialmente de Dalcídio Jurandir, o romance Belém do Grão-Pará, assim como a excelente crítica de Willi Bolle a este texto, na qual sustenta sua leitura da cidade de Belém como "porta de entrada da Amazônia" (cf. Bolle, 2008).
} 
os anos 1970. Importa sublinhar um aspecto desta dinâmica econômica e social recente, ligado, por sua vez, à dinâmica populacional, que impacta diretamente a concepção que temos de urbano e, portanto, das formas como estabelecemos as clivagens para nomear e julgar o que é e o que não é urbano.

0 crescimento das áreas urbanizadas do Centro-Sul, que alcança taxas de urbanização próximas a 90\%, distorce a percepção da conformação urbana brasileira e, em certa medida, a obscurece quando afirma a experiência metropolitana como o urbano. É bem verdade que a população brasileira concentrada nas cidades grandes e/ou nas metrópoles alcança a marca dos 30\% da população dos municípios brasileiros. Entretanto, se olharmos a distribuição da população pelas faixas de tamanho populacional dos municípios, teremos a situação abaixo.

Tabela 3 - Distribuição dos municípios e da população segundo faixas populacionais, 2010

\begin{tabular}{l|rrrr}
\hline Faixas Populacionais & No de Municípios & $\mathbf{\%}$ & População & \% \\
\hline Até 50.000 hab. & 4.958 & 89,1 & 64.063 .131 & 33,6 \\
De 50.001 a 500.000 hab. & 569 & 10,2 & 70.831 .087 & 37,1 \\
Mais de 500.000 hab. & 38 & 0,7 & 55.838 .476 & 29,3 \\
Total & 5.565 & 100,0 & 190.732 .694 & 10,0 \\
\hline
\end{tabular}

Fonte: IBGE, Censo Demográfico, 2010.

Portanto, na contramão da ideia de um país urbano-metropolitano, segundo dados do Censo de 2010, a imensa maioria dos municípios brasileiros - mais de 99\% dos 5.565 abrigam 70\% da população brasileira, ou seja, quase 135 milhões de pessoas. Sendo que destes, mais de 4,5 mil municípios abrigam menos de 500 mil habitantes cada e, ainda desse universo, quase 5 mil municípios concentram um contingente de até 50 mil habitantes. Evidentemente essa distribuição impacta a experiência urbana e também as formas de sociabilidade política que a população brasileira tem e reconhece como legítima e desejável.

Se é verdade que a população em termos absolutos está concentrada em poucas cidades e a experiência urbana desta se estabelece a partir de parâmetros metropolitanos, é preciso que se diga que a rede urbana brasileira não se restringe a essas cidades. Ademais, esse universo metropolitano, especialmente através dos polos de produção de conhecimento - sejam acadêmicos ou midiáticos - e das políticas estatais, estabelece os critérios de regulação e valoração da experiência social a partir de uma experiência 
urbana/metropolitana que se desenvolve em poucos lugares, que não pode e não é extensível para o conjunto da população brasileira. Essa valoração que descredencia uma parte substantiva da experiência urbana no país, em certa medida, expressa as imensas desigualdades regionais existentes no Brasil, as quais modelam seus territórios e, ao estruturar políticas públicas urbanas, reafirmam e aprofundam essas desigualdades.

No Brasil, apesar da intensa urbanização dos últimos cinquenta anos, é preciso tomar com alguma atenção o fato de que a população rural brasileira, desde a década de 1950, permanece significativa; variou entre 33 e 41 milhões de pessoas até 1970 e depois decresceu, até chegar aos 29 milhões no último Censo de 2010. E isso a despeito do crescimento exponencial da população urbana e da diminuição significativa dos fluxos migratórios campo-cidade, nas últimas duas décadas.

Como chama atenção Nakano, "parte dessa população rural insere-se no universo da agricultura familiar, parte vive em comunidades tradicionais e ribeirinhas e parte encontrase nos municípios periurbanos"4 (2011: 29). Ainda que nesses municípios a forma urbana seja marcada por uma duplicidade - neles podemos identificar, ao lado de intrincados traços urbanos, formas de sociabilidade e de experiência social marcadas por códigos e referências rurais -, é preciso dizer que esses territórios constituem-se em certa medida sob a lógica da moderna sociedade capitalista ${ }^{5}$. Ora, a concepção que orienta as políticas públicas brasileiras está ancorada numa percepção do urbano em contraposição ao rural6, como pares antagônicos, pertencentes a duas lógicas de funcionamento econômico e social

\footnotetext{
${ }^{4} \mathrm{O}$ termo periurbano tem sido utilizado por um conjunto de pesquisadores para designar territórios nos quais as dimensões e as lógicas de produção (econômicas mas não só) urbanas e rurais estão presentes e convivem de maneira não excludente. “Em geral, o termo 'periurbano' é utilizado para designar as áreas localizadas nas franjas periféricas de manchas urbanas consolidadas, sejam elas de grande, médio ou pequeno porte. Esta acepção da palavra "periurbano" se aproxima dos estudos sobre o 'padrão periférico de urbanização' desenvolvidos nas décadas de 1970 e 1980 por pesquisadores como, por exemplo, Ermínia Maricato, Raquel Rolnik e Nabil Bonduki, entre vários outros. (...) 0 termo 'periurbano' também é utilizado por alguns pesquisadores para designar áreas de transição urbano-rural que podem ou não estar nas franjas das grandes cidades." (Nakano, 2011: 19). É importante chamar atenção para o fato de que os órgãos de monitoramento e institutos de pesquisa do governo federal não reconhecem este termo (ou seja, não reconhecem esta realidade), o que significa que as políticas públicas especialmente as territorializadas não constroem suas estratégias de ação a partir desta realidade. Para esta discussão ver FASE, 2011; Nakano, 2011; Miranda, 2009. ${ }^{5}$ A expressão é de Karl Marx, que aproximou os termos "moderno" e "capitalismo" na sua concepção de sociedade capitalista; falar em sociedade moderna é rigorosamente falar em moderna sociedade capitalista.

${ }^{6}$ Essa discussão do rural e urbano como par antagônico está presente no próprio nascimento da sociologia e, de forma mais contundente, na constituição da sociologia urbana. Os primeiros estudos da Escola de Chicago construíram boa parte de suas pressuposições a partir desse par antagônico, seja idealizando o rural, seja superestimando o urbano como capaz de criar um novo modo de vida.
} 
mutuamente excludentes. Portanto, é preciso recolocar as cidades, suas estruturas rurais e o campo no centro de uma dinâmica territorial, de forma articulada. Ler as cidades na sua relação com o rural não é negar suas especificidades, mas é reafirmar que campo e cidade são partes integrantes de uma dinâmica socioterritorial, que congrega estruturas urbanas e rurais em tensão e mútua determinação. Importa dizer que essa dinâmica territorial em tensão, que não exclui estruturas agrárias das formas e territórios urbanos, pertence ao quadro de referências do mundo moderno, da moderna sociedade capitalista.

Sem esse deslocamento conceitual, as cidades amazônicas e a consideração do urbano na região ficam em suspensão, sem chão onde se enraizar, sem lugar a partir de onde problematizar e publicizar suas questões. A construção de uma ideia reguladora de cidade como espelho do processo de industrialização nos desautoriza a considerá-las como cidades stricto senso (e, em decorrência disso, também a sua forma, seu tamanho, sua história, as identidades e referências culturais de sua população), uma vez que não correspondem à fórmula específica de desenvolvimento econômico industrial. Por outro lado, a dinâmica socioterritorial e a história (a qual abarca, por outro lado, formas diversas do moderno), cristalizam uma visão dessas cidades e de seus habitantes (especialmente aqueles que reivindicam esta diferença) como atrasados ou arcaicos. A Amazônia, segundo essa ideia reguladora, é um lugar de não mais e ainda não, ou seja, um lugar de impossibilidade e de interdição.

\section{Amazônia, floresta intocada e desabitada: a construção de uma imagem e a ocupação territorial da região}

Num grande recorte podemos identificar dois padrões de cidades na Amazônia. 0 primeiro deles está em consonância com a dinâmica da ocupação através de atividades agroextrativistas, da qual o ciclo da borracha é a expressão mais forte. Cidades dispostas ao longo dos cursos dos rios, com ocupação de seus vales, cuja atividade econômica se sustentava em lógicas mercantis - o aviamento por excelência - e em formas diversas de organização do trabalho. Nesse arranjo é importante sublinhar o papel de Belém e Manaus, - cidades-sede por assim dizer - como lugares de comercialização da produção e como 
centros de articulação entre as outras cidades da rede. As cidades desse padrão, que se constituíram antes do ciclo da borracha, corresponderiam àquelas que Edna Castro em sua tipologia designa como "históricas ou antigas" (cf. Castro, 2008, 2010).

Esse padrão de ocupação territorial da Amazônia dará lugar, a partir dos anos 1930 com a política de integração nacional do governo de Getúlio Vargas, a outro que, resultado da ampliação e consolidação da ocupação econômica e territorial da região, se embasa na ideia de fronteira e na criação de novas cidades e povoados. Esse novo padrão de ocupação urbana teve como mola propulsora as intervenções governamentais, que funcionaram como indutor de ocupação, de crescimento e também de urbanização. Evidentemente, se a ação estatal é o vetor desse padrão de ocupação que se reafirmou nos anos 1960 com o golpe militar e se replica até os dias atuais, ele não é, porém, o único sujeito dessa ocupação. “0 espaço urbano na fronteira foi produto não só do planejamento mas da recriação social, de relações constituídas por várias gerações que acabaram por se envolver em um projeto de mudanças e desenvolvimento regional” (Castro, 2008: 22).

Se é possível estabelecer tipologias da ocupação urbana, também é preciso historicizar, no seu movimento e nas suas tensões, as formas diferentes de seu desenvolvimento. Esse olhar mais aproximado nos permitirá perceber a articulação entre as políticas de desenvolvimento regional, esses padrões de ocupação, imagens e práticas discursivas que cercaram e cercam ainda hoje a Amazônia.

Tomemos como ponto de partida dessa historicização, a permanência, nos discursos e imagens que cercam a Amazônia, da representação, que compõe o imaginário de parte da população brasileira que não vive ali, da região como um lugar inexplorado, vazio de pessoas e culturas, espaço da natureza intocada, habitado por grupos e coletividades submetidos a condições pouco desenvolvidas. As razões dessa representação que reatualiza o mito de uma floresta como o eldorado - seja na versão da salvação do Brasil, como pulmão e celeiro do mundo, seja mais recentemente, como o berço da biodiversidade planetária - estão em diálogo com a sua ocupação pelos portugueses, cujo centro foi a fundação de São Luis, Belém e Manaus:

0 avanço foi lento. Tendo iniciado a conquista da Paraíba em 1583, só em 1615 tomam o Maranhão aos franceses; e, prosseguindo, fundam próximo ao delta do Amazonas uma fortaleza, origem da cidade de Belém. 
A partir dai dá-se a gradativa expulsão dos concorrentes na Amazônia. Concomitantemente, inicia-se uma fase de explorações, onde avulta a viagem de Pedro Teixeira pelo Amazonas em 1637-39. Para isto concorreram inicialmente as narrativas sobre a existência de ouro trazidas pelos navegadores espanhóis que desceram o rio no século XVI (Velho, 2009: 12).

É possível também dizer que essa porção do Brasil tem, desde sua incorporação às terras coloniais, uma relação de estranhamento com o restante do país, dado que os vetores de colonização do Brasil não resultaram na ocupação efetiva de território. A Amazônia, ao contrário,

[...] permaneceu séculos numa situação de grande marginalização em relação ao mundo, mas especialmente em relação ao próprio Brasil. Isso se agravou com a desintegração do sistema de exploração da mão-de-obra indígena dos jesuítas e a decadência da zona agrícola. As comunicações se davam diretamente com Lisboa, e não é por acaso que lá se organizou um dos focos de resistência ao movimento de 1822 .

Todavia, tal como a economia pecuarista subsidiária esteve ligada a uma significativa expansão territorial, o mesmo ocorreu em grau maior ainda com a incipiente extração das drogas do sertão. A diferença está em que a relação com o restante do país foi ainda mais precária e muito mais acidental.

O território que com isso se assegurou para o futuro foi dos mais expressivos. Isso se deveu em parte à fraqueza do movimento de expansão vindo do Pacífico, dado o tipo de economia que lá se desenvolveu, fundamentalmente concentrada para oeste do obstáculo físico dos Andes desde a descoberta das minas. Deve-se também à orientação do eixo principal de penetração - o Amazonas, e ao gênero de ocupação que se afirmou: ralo, linear, ao longo dos rios. A floresta manteve-se em grande parte intocada, embora em termos políticos relativamente assegurada. Era o que se podia realizar em face da orientação colonial e mercantil da exploração e dos atrativos que nesse sentido oferecia a região. (Velho, 2009: 29) 
Com Getúlio Vargas e Juscelino Kubitschek, a Amazônia esteve no centro da constituição da ideia de brasilidade, de formas diferentes, é verdade, mas ainda cumprindo o papel de sinalizar através da integração de vastas áreas do território brasileiro longe e de difícil acesso (conhecimento e exploração), a construção da nação brasileira e de incorporação civilizatória de povos e territórios distantes até aquele momento. 0 Programa Marcha para o Oeste, de 1937, em pleno Estado Novo, declara abertamente seu componente civilizatório, que leu na Amazônia o resíduo não civilizado e atrasado a ser incorporado ao Brasil moderno que então ali se constituía. Essa imagem quase espectral da Amazônia e de seus povos coaduna com a leitura de extração autoritária que percebe nas múltiplas contribuições culturais e étnicas um problema na formação social brasileira, na constituição da nação e na organização política de seu povo. Exemplar desse tipo de leitura, a obra de Oliveira Vianna7 percebe na formação brasileira um vazio social sobre o qual o Estado autoritário deve agir no sentido de construir uma sociedade e, assim, uma nação.

Com o governo JK (1956-1961) e o aprofundamento de uma ideia de desenvolvimento e de avanço rumo a um sociedade moderna e industrializada, a retomada da Marcha para o Oeste concretizar-se-á na construção da rodovia Belém-Brasília, no âmbito do Plano de Metas. Para crescer os “cinquenta anos em cinco" com o objetivo de fazer o país superar seu subdesenvolvimento, foram necessários vultuosos investimentos estatais em infraestrutura e na indústria de base. No que dizia respeito às terras amazônicas, urgia integrar efetivamente esse território ao Brasil através da expansão da rede urbana para as regiões despovoadas, articulando urbanização e industrialização, o que lhes daria condições de superar suas mazelas. Se esse plano de desenvolvimento não estabelecia a Amazônia como locus da indústria, certamente a tomava como área importante no funcionamento geral do sistema de industrialização do país. A imagem de Bernardo Sayão como "último bandeirante, derrubando árvores, rasgando a selva, construindo cidades e trazendo o progresso e o desenvolvimento" dava o tom do projeto de integração e desenvolvimento.

\footnotetext{
${ }^{7}$ Os dois volumes de Populações meridionais do Brasil, dedicados às populações rurais do Centro-sul e do Sul, integravam o projeto de pesquisa de Oliveira Vianna, que abarcava as diversas formas de organização socioeconômica brasileira, analisando suas similitudes e singularidades. Do projeto original, constava um terceiro estudo sobre a região Norte, notadamente a Amazônia, que não chegou a ser escrito. Contudo, o autor deixou as indicações de que, para ele, a Amazônia corroborava a sua percepção de uma sociedade civil brasileira amorfa (Cf. Oliveira Vianna, 1987).
} 
A integração, nessa perspectiva, é vista pela infraestrutura, por obras de engenharia de transporte que tiveram certamente eficácia no avanço da fronteira agrícola e econômica. É o caso da rodovia Belém-Brasília, que atravessa territórios dos estados do Pará, Maranhão, Tocantins e Goiás e cruza a rodovia da Transamazônica, ligando outros estados do Norte Rondônia, Acre e Mato Grosso - às regiões Nordeste, Sul e Sudeste do país. Colonização, estradas e grandes projetos constituem elementos do pilar da política de integração nacional. São, portanto, investimentos na construção de infraestrutura que viabilizaram o avanço de grandes espaços na Amazônia (Castro, 2010: 110).

Nessa imagem da integração posta em funcionamento, é justamente a ocupação anterior desse território e a existência aí de sujeitos que está em negativo. Desse modo, a constituição da modernidade e da modernização econômica brasileira reafirma para amplas camadas e grupos sociais, mais uma vez, esse "lugar sem lugar", ou um lugar vazio de sujeitos. A rodovia Belém-Brasília - articulada à construção da nova capital e à ocupação do território - parece ser a obra que melhor condensa esse projeto de integração nacional, cujo núcleo era o Estado indutor e assegurador dos investimentos econômicos privados, que entendia o desenvolvimento econômico da nação nos moldes estritos da sociedade industrial. No mesmo movimento, para a o surgimento desse Brasil moderno, urgia constituir os sujeitos dessa nova sociedade, que pouco ou nada se aproximavam dos sujeitos de carne, osso, história e cultura que ali já estavam presentes.

Para os interesses desta tese, cumpre reafirmar que a Amazônia continua a ser pensada como um imenso vazio, seja de extensão geográfica, seja de sujeitos. Aqueles que ali vivem ainda estariam "à espera do progresso", e devem ser integrados ao Brasil, não a partir de suas especificidades, mas sim da perspectiva da incorporação de "massas populacionais".

Já no pós-Golpe Militar de 1964, as ações e planos para Amazônia reproduzem o núcleo do projeto desenvolvimentista de JK: continua em cena a saga de integração como elemento ideológico fundamental que organiza a intervenção na região, cujo ícone é o desbravador/bandeirante e sua missão de humanização e civilização do seu outro. Nessa 
disputa ideológica, mobiliza-se a imagem da integração de mundos muito diferentes; o civilizador, moderno versus o não moderno, personificado nas figuras do camponês, do caboclo, do indígena, do ribeirinho, entre outros. Mas, para ser fiel à realidade, o que está em jogo é a incorporação de novas fronteiras de exploração econômica ao mercado e ao "movimento de racionalização do capital" (Castro, 2010: 111).

É verdade que a saga de integração é o fio condutor que se mantém entre diversos projetos e programas de intervenção para a região antes dos anos 1960 e depois: o Programa da Marcha para o Oeste, de 1937, a Expedição Roncador Xingu, de 1943, o Programa Rondon - já sob o julgo dos militares -, em 1967, o Programa de Integração Nacional, de 1970 e os programas Poloamazônia, em 1976 e Polonoroeste, em 1986. Entretanto, há que se considerar que, no período posterior ao Golpe Militar de 1964, agrega-se um novo elemento às intervenções estatais, combinando ações de "tamponamento das fronteiras" aos interesses econômicos na região:

Amazônia vai ganhando importância como uma área a ser defendida, o que só seria politicamente viável a partir de um forte entrelaçamento entre os interessados na área e o Estado brasileiro; traduzindo, era preciso que valesse a pena defender a soberania brasileira sobre o território. (Oliveira, 1994: 4).

Por esse prisma, as ações e programas ganham novo relevo e percebemos sua centralidade no âmbito do pensamento geopolítico brasileiro da época, de extração autoritária, retomando um aspecto que, desde os tempos coloniais, estava em questão: naquela época tratava-se de garantir a ocupação da Amazônia pelos portugueses, hoje, pelos brasileiros, ou mais precisamente pelo Estado brasileiro. Esse enorme "vazio verde" cumpriu também uma importante função interna no que dizia respeito ao trato com os "inimigos internos" da ditadura militar, isto é, na política empreendida por esta de aniquilamento das organizações populares e de esquerda. Os inimigos internos, naquele caso, foram as levas de trabalhadores rurais pobres e expulsos de suas terras, que, no Nordeste, organizados nas Ligas Camponesas, faziam crescer a pressão por uma reforma agrária que minimamente correspondesse à demanda de democratização do acesso à terra na região. A Amazônia, e antes o Maranhão, passou a servir como um "pulmão", ajudando 
naquele momento a diminuir as tensões e conflitos agrários no país. Não à toa, o projeto de colonização para a região centra-se justamente neste aspecto: uma terra sem homens para homens sem terra.

Podemos dizer, concordando com Francisco de Oliveira (1994), que "a reconquista da Amazônia" então, é um amálgama entre geopolítica e segurança nacional: a construção de grandes estradas como a Transamazônica para garantir as fronteiras, por um lado, e a distribuição de terras para assentar agricultores vindos de fora, por outro. É o lema "integrar para não entregar" que, de certa maneira, já estava presente antes desse período ditatorial, mas que somente foi formulada nesses termos pelos militares.

A leitura de Oliveira sobre a "recente" 8 ocupação da Amazônia, chama atenção para dois aspectos importantes. 0 primeiro diz respeito ao centro indutor dessa ocupação no final dos anos 1980 e começo dos 1990:

A anterior digressão [sobre o período militar e sua política para Amazônia] se faz para lembrar que os projetos integracionistas não eram, portanto, projetos da expansão econômica de São Paulo, o que, no caso da Amazônia, forneceria uma chave falsa, economicista, para o processo da ulterior expansão capitalista na região. Essa incapacidade de hegemonia de São Paulo, notável também na forma em que se resolveu a "questão regional" clássica no Brasil - a questão do Nordeste —, comparece, aqui, também na questão da Amazônia. E a Belém-Brasília abriu o passo ao aparecimento de forças centrífugas no processo da expansão econômica, bafejadas, por certo, pela acumulação primitiva do "assalto ao Tesouro", mas não ligadas ao capital paulista. É o movimento constitutivo da nouvelle bourgeoisie brasiliense, os Paulos Octávios da vida, com sua ridícula - et pour cause ostentação kitsch, jardins da Casa da Dinda (Oliveira, 1994: 6).

Além de retomar a questão regional brasileira como elemento importante para compreensão do papel da Amazônia no jogo econômico e político do país, o autor sugere

\footnotetext{
8 Utilizo aqui o termo "recente" para respeitar a nomenclatura do autor e chamar a atenção para um descompasso. 0 artigo citado trata da reconquista da Amazônia e regressa até o período militar para compreender a onda em curso naquele momento de exploração da região. Publicado em 1994, não poderia abordar o debate sobre a exploração da Amazônia em curso nos últimos vinte anos, ancorada, em grande medida, num discurso "verde" que legitima grandes empreendimentos na região.
} 
que essa expansão e reconquista têm a ver com a constituição no Brasil de um novo circuito do capital e de uma nova hegemonia política durante os governos de Fernando Collor de Melo e Fernando Henrique Cardoso. Tal sugestão nos autoriza a afirmar a importância que a Amazônia terá nos anos 1990 e 2000 na conquista de novas fronteiras de acumulação, articulando, no bojo da reorganização do Estado brasileiro nos anos 1990, parte da burguesia brasileira aos circuitos financeirizados do capital. Essa articulação, que tem na nova fronteira ambiental um polo dinâmico, será impulsionada e sustentada pelas profundas mudanças tecnológicas e biotecnológicas que nesse período se apresentam (Santos, 2003).

O surgimento do discurso ambiental e a força que este adquire a partir dos anos 1970 e 1980 agregam um elemento a mais nesse campo de conflitos. Tanto durante o governo de Juscelino Kubitschek quanto o militar, nas ações na região amazônica, as questões ambientais não comparecem positivamente como elemento de construção da intervenção e do desenvolvimento, elas surgem apenas em negativo, demarcando a Amazônia como um "reduto da natureza", uma espécie de papel em branco, sem povos, sem sujeitos. Henri Acselrad (2010) chama de "ambientalização dos Estados nacionais" a montagem de sistemas institucionais responsáveis pelas políticas ditas ambientais, a partir dos anos 1970, com impacto direto na Amazônia. Naquele momento despontaram as pressões ambientais presentes nas lutas concretas de povos e populações impactados pela "chegada do progresso", como diria o bode Orelana9 . Configurou-se assim um polo antagônico e de resistência a estas ações de desenvolvimento, de forma dissensual e conflitiva, através da encenação política que questiona o sentido/significado dessas ações e da partilha do sensível ${ }^{10}$.

\footnotetext{
${ }^{9} \mathrm{O}$ bode Francisco Orelana é um personagem do cartunista Henfil, que vivia no sertão nordestino junto com a Graúna e o cangaceiro Zeferino. O bode intelectual do sertão adquiria seus conhecimentos e crítica mastigando - literalmente - livros e jornais. Os três protagonizam muitas cenas nas quais estão à espera da chuva e do progresso que viria (mas nunca chegou) do "Sul maravilha". Coincidentemente, Francisco Orellana, navegador e explorador que servia a Coroa Espanhola, foi o primeiro europeu a comandar uma expedição que percorreu por inteiro o Rio Amazonas, descendo do Peru até sua foz em 1541, e é por causa de uma de suas narrativas sobre índias guerreiras que teriam combatido sua expedição, que nome do maior rio do mundo é Amazonas. Há ainda outra história que advoga que o nome do Rio Amazonas vem de "amassona", palavra indígena que significa "barco destruído", que foi o destino da expedição comandada pelo espanhol Orellana.

10 Trataremos desta subjetivação política, nos termos de Jacques Rancière, ainda neste capítulo.
} 
O segundo aspecto assinalado por Francisco de Oliveira e por outros autores, diz respeito ao caráter autoritário dessa ocupação e das mediações sociais que a legitimam. É importante reter desse processo de acumulação primitiva, por um lado, o papel de protagonista assumido pelo Estado na indução da ocupação por meio de obras de infraestrutura que permitiram a instalação de atividades produtivas levadas a cabo por ele mesmo, especialmente através de empresas estatais. Esse caráter autoritário distingue-se em duas formas pouco definidas à primeira vista. Durante a ditadura, tratava-se de uma violência imediata, que não precisava recorrer a mediações e dissimulações no trato com os oponentes , ainda que os militares, a despeito desse uso da coerção e da violência, tenham feito um grande investimento para legitimar a ampliação das novas fronteiras econômicas frente o conjunto da população, como argumentamos acima. A outra forma - e esta interessa mais diretamente aqui, haja vista que é com ela que continuamos a lidar no tempo presente -, é a da "violência mediatizada", nas palavras de Oliveira (1994); aquela que, passada a fase inicial de abertura de novas fronteiras, é própria da acumulação capitalista e que, em certo sentido, opera nas formas de exploração e desenvolvimento econômico que se estabeleceram na região. A mudança de "acumulação primitiva" para "acumulação capitalista" não é uma sutil mudança de termos; marca justamente essa subsunção da violência daquela ${ }^{11}$ nas formas de reprodução do capital.

É justamente na resistência a essa violência mediatizada na expropriação das terras nas quais vivem inúmeros povos, comunidades e grupos, que a falácia da imagem da Amazônia desabitada e "natural" é revelada, justamente pela encenação política que estes "não contados"12 desencadeiam com sua aparição e no processo de subjetivação política que operam (Rancière, 1996). Se a raiz autoritária dessas intervenções - tanto antes quanto agora - estavam/estão na construção de uma imagem que afirma "as sociedades, comunidades, tribos, nações indígenas e etnias locais e regionais não teriam forças, competência técnica, recursos financeiros, poderes abrangentes para superá-los" (Oliveira, 1994: 6), é na contraposição à violência desse modelo de desenvolvimento econômico que

\footnotetext{
11 Estes processos - acumulação primitiva e acumulação capitalista - ainda que tenham relação, não são categorias históricas, ou melhor, não se encerram em uma linha cronológica; constantemente estão em operação, o que nos autoriza dizer que são elementos analíticos retirados da história, como bem sabemos da teoria de Marx, mas não petrificados como categorias temporais.

12 Rancière utiliza a noção de "não contados" de forma não literal.
} 
vemos surgir politicamente os povos da floresta em suas diversas e diferentes formas de vida e de organização.

Nesse embate desigual o que se confronta, além da defesa de territórios e da própria possibilidade de continuar existindo, são mundos, formas de vida, quadros epistemológicos e registros axiológicos diversos.

A questão da Amazônia pega o Estado brasileiro no contrapé de uma crise sem precedentes, reduzindo-lhe a capacidade de que o exercício formal do monopólio da violência transforme-se na capacidade de criação de canais que publicizem as relações sociais. Além disso, a crise do Estado moderno aparece na Amazônia dramaticamente: onde começa e onde acaba o território legal do moderno Estado Nacional? A supranacionalidade dos conflitos e das nações indígenas interroga gravemente o conceito e a prática do Estado-nação. A que o Estado brasileiro replica, apenas, com a militarização da região; esse mesmo conceito e sua realidade perguntam-se: região de qual Estado Nacional? (Oliveira, 1994: 13)

\section{Luzes na floresta: os sujeitos da Pan-Amazônia}

Se é possível argumentar, concordando com os autores aqui trazidos, que a imagem de uma Amazônia inabitada, desprovida de cultura e de vida social é elemento importante na ampliação das fronteiras econômicas e na integração desse território ao conjunto das estratégias de desenvolvimento econômico do país, como procuramos demonstrar acima, é necessário reconhecer que esse processo mudou de forma ao longo da história e, sobretudo, perceber as formas de resistência que, nele e contra ele, se gestaram.

Não é objetivo desta tese, muito menos deste capítulo, recompor em detalhe a constituição dessa resistência. Interessa, entretanto, apontar/analisar quais as conexões que esse processo estabelece com o da participação popular na cidade de Belém - seja através de seus conteúdos, das relações entre seus sujeitos, ou, ainda, pela maneira como esses conteúdos estão presentes politicamente na pauta municipal e como esses sujeitos verbalizam uma posição que ecoa nas formas urbanas de vida e luta política, interpelando dessa maneira - é o que aqui argumento - a vida política nacional e suas formulações. 
Em uma passagem de Jacques Rancière sobre a política ser um processo de subjetivação mais do que um jogo aritmético de ganhos e perdas, está o que anima a perspectiva de leitura e a orientação teórica defendida aqui:

A política é a prática na qual a lógica do traço igualitário assume a forma de tratamento de um dano, onde ela se torna o argumento de um dano principal que vem ligar-se a tal litígio determinado na divisão das ocupações, das funções e dos lugares. Ela existe mediante sujeitos ou dispositivos de subjetivação específicos. [...] A política é assunto de sujeitos, ou melhor, de modos de subjetivação. Por subjetivação vamos entender a produção, por uma série de atos, de uma instância e de uma capacidade de enunciação que não eram identificáveis num campo de experiência dado, cuja identificação portanto caminha a par com a reconfiguração do campo da experiência. [...] Toda subjetivação política é uma desidentificação, o arrancar à naturalidade de um lugar, a abertura de um espaço de sujeito onde qualquer um pode contar-se porque é o espaço de uma contagem dos incontados, do relacionamento entre uma parcela e uma ausência de parcela. (Rancière, 1996: 47-48 [grifos no original])

Nesse processo de subjetivação conflituoso e dissensual por definição, o coração da política está justamente no ato de sujeitos encenarem a sua própria condição, produzindo "essas cenas polêmicas, essas cenas paradoxais que revelam a contradição de duas lógicas" (Rancière, 1996: 52), arrancando sua experiência de exploração e desigualdade da naturalidade ou, do lugar de esquecimento.

Jacques Rancière (1996) aprofunda a sua concepção da política e, debruçando-se sobre os textos nos quais Aristóteles discute a democracia, ancora aí sua formulação: toda política fundamenta-se na igualdade de "qualquer um com qualquer um", ou, por outra via, na ausência de uma arkhé que habilite este ou aquele para o exercício do poder. A partir dessa concepção de política, Rancière criticará duramente a república ${ }^{13}$ ou outras formas de vida política que pressupõem algum título ou legitimidade anterior para seu exercício. Essa

\footnotetext{
13 Rancière discorda frontalmente de Platão acerca das concepções deste de vida pública e de república, esta discussão está presente ao longo de seu trabalho e em especial, no livro $O$ ódio à democracia (Racière, 2005). Retomaremos esta discussão no capítulo 5.
} 
crítica funda-se no fato da igualdade na sua acepção não ser um dado que se aplica à realidade na política, nem mesmo um objetivo. A igualdade é precisamente a pressuposição da vida política. Essa pressuposição de uma igualdade contingente permite, através de conflitos e litígios, questionar toda desigualdade que estrutura a vida social. Podemos então argumentar que a política é esta igualdade contingente que aparece sob o nome de liberdade e interrompe a ordem natural da dominação, produzindo um litígio acerca da divisão da sociedade, suas partes e sua contagem.

É possível, grosso modo, identificar duas constelações de grupos e movimentos, sujeitos políticos da resistência ao modelo hegemônico de ocupação da região amazônica. Argumento em favor de uma leitura que não identifique um momento fundador para esses sujeitos, mas que perceba nas tensões enraizadas na sua história, as formas de subjetivação política que constroem, no período recente, essa constelação de sentidos contestadores da imagem da Amazônia como um vazio e da ação política que esta última legitima. É justamete no percurso dessa construção coletiva de sujeitos diversos, dentro de uma orientação popular e contestatória, que a questão amazônica ganhou projeção nos últimos vinte anos. Por um lado, o movimento ambientalista ${ }^{14}$, por assim dizer, de extração menos popular e mais intelectualizada, tributário de lutas e tradições ecológicas e ambientais emergentes no Brasil durante os anos 1970 e 1980, e, de outro, movimentos sociais populares, enraizados nos lugares de embate e conflito, nos quais veremos surgir na contraface dos tais projetos de desenvolvimento, grupos, organizações, movimentos. Importa enfatizar que o aparecimento público desse conjunto mais ou menos articulado de grupos, comunidades e movimentos não significa sua não existência anterior.

\footnotetext{
$14 \mathrm{O}$ artigo de Henri Acselrad (2010) recupera as diversas clivagens e diferenças dentro do campo do chamado "movimento ambientalista". O autor recorre à ideia de uma "nebulosa associativa" para argumentar que no interior desse campo estão sujeitos e motivações muito díspares, até mesmo conflitantes, e mostrar as disputas ali. 0 autor aponta uma despontecialização do discurso ambiental no país ao longo dos anos 2000, com 'O 'deslocamento' assim configurado no movimento de transformação do 'confronto em colaboração', procurando fazer do embate ecológico uma dimensão da "parceria entre sociedade civil e governos", não teria, porém, sido bem-sucedido junto ao que é visto como um ecologismo socialmente enraizado. Tratar-se-ia, assim, para os atores desse ecologismo contestatório, de tentar preservar o espaço da crítica ambientalista ao modelo de desenvolvimento e de fazer que a questão ambiental pudesse constar da elaboração de um projeto político contra-hegemônico." (Acselrad, 2010: 107). O autor segue mostrando como naquele período se plasmou o que ele nomeia como movimento por justiça ambiental, que tem na constituição da Rede Brasileira de Justiça Ambiental um elemento central. Em torno desta, reúnem-se entidades da sociedade civil, movimentos sociais e pesquisadores que tem tido uma importante participação em ações como a contestação dos laudos técnicos que aprovam grandes projetos como a usina de Belo Monte. Ver também artigo de Leite Lopes, 2008.
} 
A constituição de uma questão política (ou, nos termos de Rancière, da subjetivação política) em torno da Amazônia é fruto do conflito e do dissenso que se arma uma cena pública a partir justamente da fala dos povos da floresta e de comunidades tradicionais, contrapostos, neste meio de caminho, ao desenvolvimento, seja na ditadura, nos anos de democratização ou na década do desmanche ${ }^{15}$, assumindo diversas pautas e configurações. A história de luta dos seringueiros no Acre talvez seja a mais emblemática construção desse tipo. Ações que reivindicam o direito de existência, sua preocupação com as futuras gerações, uma relação não mercantilizada com a natureza, conformadas por um quadro epistemológico e axiológico diverso do moderno ou em tensão com este. Práticas e disputas do sensível que montam uma cena pública contestadora dos sentidos do projeto de desenvolvimento econômico que está sendo implementado na região e que, como procuramos demonstrar antes, acionou/aciona uma imagem da Amazônia para sua legitimação.

A contestação dessa imagem de vazio revela uma Amazônia plena de conflitos e sujeitos, cujas formas de organização colocam em discussão a sociedade brasileira e seu processo de modernização. Nessa construção está em pauta uma nova forma de partilha do sensível. Longe de uma visão que desqualifica a participação dos setores médios, da intelectualidade e dos chamados "formadores de opinião", não quero dizer que esses povos são os únicos sujeitos da resistência e da contestação. É de fundamental importância a contribuição de setores como as redes de pesquisadores, os professores mais ou menos alinhados aos grupos da floresta, entidades não governamentais e outras organizações não propriamente "da floresta" ou tradicionais, mas que se articulam e constroem essa resistência de múltiplas formas e frentes.

Contudo, quero sublinhar que essa elaboração coletiva por excelência se faz a partir da experiência de enfrentamento cotidiano desses povos com as ações dos planos estatais e com as formas de expansão econômica que estes subsidiam. Ou seja, essa elaboração se constitui no âmbito de uma experiência social, política e de modos de vida próprios. A força dessa subjetivação política reside justamente aí, na exigência de reconhecimento de seu

\footnotetext{
150 termo é de Roberto Schwarz, referindo-se ao encolhimento da ação estatal no que diz respeito às políticas públicas de cunho universal, no âmbito das transformações da economia operadas no decurso dos anos 1990, no Brasil.
} 
pertencimento a esta comunidade política que se nomeia como Brasil. Essa perspectiva nos autoriza a enfatizar que os modos de vida e as formas pelas quais esses povos e comunidades compreendem o mundo são fundamentais na constituição dessa voz dissonante que interpela os projetos na Amazônia, por uma nova partilha do sensível ${ }^{16}$.

Um mecanismo discursivo e político de questionamento dos lugares e da divisão das parcelas no presente e na construção desse futuro é acionado pela resistência dessas nações indígenas, ribeirinhos, seringueiros, sem-terra acampados, quebradeiras de coco de babaçu, pescadores, comunidades tradicionais, sindicalistas, pequenos produtores rurais entre tantos outros. Estes são sujeitos políticos em sentido alargado porque multiétnico e multicultural, mas não frouxo porque balizado por uma determinada visão compartilhada do futuro, figuração do outro deste Brasil industrializado, desenvolvido, moderno.

Esses povos e comunidades estão dizendo que a sua existência e suas formas de vida (que alcança os vínculos entre natureza, trabalho e cultura) supõem a existência de outros povos diferentes e diversos, mas que têm o mesmo direito de existir. Nessa organização e articulação de suas lutas, o dispositivo acionado me parece ser o da igualdade contingente.

\footnotetext{
${ }^{16}$ Neste sentido, há que se dizer da importância do Projeto Nova Cartografia Social da Amazônia que tem por objetivo a autocartografia de povos, grupos e comunidades tradicionais da Amazônia. 0 processo de autocartografia é demandado pelos povos e comunidades ao PNCSA e deste contato constitui-se um processo de elaboração conjunta entre as comunidades e os pesquisadores do Projeto. "Estas territorialidades específicas, construídas socialmente pelos diversos agentes sociais, é que suportam as identidades coletivas objetivadas em movimentos sociais. A força deste processo de territorialização diferenciada constitui o objeto deste projeto. A cartografia se mostra como um elemento de combate. A sua produção é um dos momentos possíveis para a autoafirmação social. É nesse sentido que o PNCSA busca materializar a manifestação da autocartografia dos povos e comunidades nos fascículos que publica, que não só pretendem fortalecer os movimentos, mas o fazem mediante a transparência de suas expressões culturais diversas" (PNCSA, sítio eletrônico). Estes momentos de construção da autocartografia e, sobretudo, seus desdobramentos tornam visíveis sujeitos que estão fora dos sistemas consagrados de registro normativo e, mais do que isto, fora da política. É importante sublinhar o fato de que esta ação de incorporação do tempo ao espaço mortificado dos mapas construídos tantas e muitas vezes para a dominação de territórios e dos povos que ali vivem, é uma ação política. "Neste contexto [de conflitos ambientais], nos mapas que procuram incorporar a historicidade dos processos sociais, o espaço torna-se um vasto tabuleiro de xadrez sobre o qual os sujeitos sociais evoluem, se deslocam, se orientam. A delimitação do espaço torna-se, assim, não mais um meio de representá-lo simplesmente pelos objetos geográficos que o compõem, mas pelos conhecimentos associados a seu uso e pela intenção política que preside a sua apropriação. A representação desses territórios, onde se incorpora o conhecimento dos diferentes interesses, assim como o conflito entre seus distintos projetos, abre, pois, ao debate a questão da legitimidade do poder que sobre eles se exerce." (Acselrad, s/d). O PNCSA acompanhou em Belém atividades de autocartografia que compuseram a série Movimentos Sociais e Conflitos nas Cidades da Amazônia, se autocartografaram indígenas, catadores, afro-religiosos, homossexuais, negras e negros, ribeirinhos, entre outros grupos que vivem em Belém.
} 
No fundo, as formas de organização dos "novos" grupos e movimentos sociais articulados em torno das questões socioambientais é parte fundamental de sua pauta política, no sentido em que a sua organização política expressa uma visão de mundo.

É através desses encontros dos índios [que se formou a Associação dos Indígenas da Área Metropolitana de Belém, AIAMB]. 0 primeiro foi... em 1979, estive lá contra a instalação da hidrelétrica de Belo Monte, de Xingu. E de lá pra cá, voltei novamente... uns tempos agora, voltei novamente neste ano... 1989, quando teve... [mostrando o vídeo de reunião dos povos indígenas contra Belo Monte] Tuíra, né, ela já está mais idosa agora. Eles são contra a construção da hidrelétrica de Belo Monte, no Xingu. O que é que nós achamos disto? Vai acabar com os peixes, vai poluir o meio ambiente, total, porque só nós conhecemos como a natureza vive. Porque o deus fez a natureza não pra o homem estragar a natureza, porque a natureza é obra de deus, ele não aceita isto porque vai acabar com peixes, os rios vai ficar represado, e vai inundar, os ribeirinhos vai se tornar a moradia ruim, entendeu? E estas coisas a gente não aceita esta construção. Aí o homem branco chega e diz assim: isto vai ser muito bom, vai gerar muito emprego. Não gera porque os índios não têm condição, muitos índios não têm ainda condição de trabalhar no sistema do branco. Então, a gente tem ainda que caminhar com isto. Por isto que nós estamos criando uma associação pra nós podermos apoiar todas as reivindicações, informar o que está acontecendo aqui, o que o governo quer fazer aqui, o que quer fazer na aldeia, criação de projetos e estas coisas. Muitos projetos são cruciais pra nós. [...] Construção de estrada, represa de rios, construção de hidrelétrica... e também instalação de mineradoras, latifundiários, fazendeiros, estes tipos, estes grupos de pessoas é prejudicial pra nós índios. É por isto que nós queremos destacar, aprender a lei do branco e... toda a cultura do branco. Você imagine porque a Funai não tem mais aquele peso pra nós que teve, de preservar o direito que a gente tem. Tá muito fraco. Então, nós temos que buscar solução através de sabedoria. A cultura [...] diferenciar a 
cultura do branco. Esta coisa que a gente tá indo buscar pra nós, pra nós termos a segurança de vida ${ }^{17}$.

Este fragmento de fala de seu Kabá sobre sua trajetória política deixa transparecer o entrelaçamento entre as lutas dos povos da floresta e as lutas que tiveram Belém como palco, não de maneira mecânica ou estanque, mas como constituição de uma visão de futuro partilhada e de ação política coletiva. Trata-se do mesmo contexto de mobilização que polariza a cena política brasileira: o enfrentamento entre um ciclo de desregulação da economia e o corpo jurídico que garante direitos estabelecidos a partir de lutas e conquistas dos trabalhadores no Brasil. Não é sem importância o fato de que os 500 anos da conquista, comemorados durante o período do governo de Fernando Henrique Cardoso, mobilizaram movimentos aparentemente não concernidos nesta disputa simbólica.

Eu atuava em defesa dos índios. [...] É, e depois, em 1967, eu passei um ano no Rio Paru também, como é que se diz, em defesa... em defesa dos índios Aparaí. 0 que a gente estava fazendo? Tinha o pastor evangélico que ele ia levando tudo pras Guianas Francesas, e lá eles trabalhavam como escravo, quebrando pedra e casas. Aí o governo naquela época, a CNBB eu estava ligado a eles, foi enviado para lá pra verificar. Mas quando eu cheguei, eu consegui a volta dos índios para... pr'aquela área do rio Paru. E desde lá eu me tornei conhecido. Quando chegou o 2000, que fizemos uma grande mobilização, pra irmos até Brasília reivindicar, na época do Fernando Henrique que era presidente da República, ele fez um evento pro governo dos portugueses, dizendo que eles descobriram o Brasil. E nós fomos contra esse tipo de matéria. Porque onde nós éramos donos do lugar onde eles encontraram, era nós que devia ser convidado pra festa especial, e nós não fomos convidados. Aí nós mobilizamos todas as federações dos índios do Brasil e fomos pra lá. Era três mil e tanto a quantidade que nós fomos a pé, na aldeia dos Pataxó, Monte Pascoal. E de Monte Pascoal, nós fomos fazer a nossa programação de festa lá na Coroa Vermelha, na Bahia. (Emílio Kabá, 4 de agosto de 2009).

\footnotetext{
${ }^{17}$ Emílio Kabá, entrevista concedida à pesquisadora sobre sua participação no Congresso da Cidade, do qual foi delegado e conselheiro. A entrevista foi realiza em sua casa, em 4 de agosto de 2009. Importante liderança munduruku, seu Kabá mora em Benevides na região metropolitana de Belém, é fundador e presidente da AIAMB (Associação dos Indígenas da Área Metropolitana de Belém).
} 
Argumentei que a experiência que se desenvolveu em Belém entre os anos de 1997 e 2004, foi fundamental nessa encenação política, dissensual e conflitiva, e na articulação amazônica ${ }^{18}$ e pan-amazônica ${ }^{19}$. Nesse contexto de embate e de disputa sobre os rumos do desenvolvimento no país e sendo parte atuante dele que, em 1996, Edmilson Rodrigues foi eleito prefeito da cidade de Belém. Era o segundo ano do primeiro mandato de Fernando Henrique Cardoso, momento de desmonte do estado e da regulação pública através das privatizações das empresas estatais e do desmonte do arcabouço jurídico de regulação do trabalho. No âmbito das políticas públicas, opera-se o encolhimento do financiamento público de programas universais e aprofunda-se a focalização da ação estatal através de programas sociais específicos e direcionados.

Em meio à transformação da base produtiva e seu impacto na experiência social e na sociabilidade política no Brasil, essas formas de aparecimento político, de subjetivação política, na contramão desse processo de encolhimento do estado na regulação pública, em Belém, a gestão municipal recém-eleita afirma um projeto político no qual o Estado tem papel fundamental na garantia de direitos e no enfrentamento dos interesses privados. É preciso ainda dizer, para explicitar os vínculos entre estes processos constituídos desde a floresta e desde a cidade de Belém, que a Coordenadoria de Relações Exteriores municipal é um dos principais articuladores do I Fórum Social Pan-Amazônico, realizado em 2002, além de ter sido o pivô institucional que viabilizou Belém como sede do II Encontro Americano pela Humanidade e contra o Neoliberalismo, em dezembro de 199920.

É desta constelação de disputas que as formas de participação popular em Belém estão referidas que nos ocuparemos a seguir.

\footnotetext{
18 A Pan-Amazônia do ponto de vista geofísico engloba os territórios cobertos pela floresta Amazônica no Brasil e em seus vizinhos Colômbia, Peru, Venezuela, Equador, Bolívia, as Guianas e o Suriname. Entretanto, no processo de resistência, luta e articulação daqueles que ali vivem, os povos e os movimentos sociais se apropriaram do termo, tornando-o um nome de luta, em torno do qual se organizam diversos povos que vivem em conflito com os setores empresariais e as diversas formas de exploração da região. Em 2002, criouse o Fórum Social Pan-Amazônico no bojo do Fórum Social Mundial. Hoje o FSPA articula mais de quarenta organizações e movimentos sociais, e realizará no final de 2012, o seu sexto encontro na Bolívia.

19 Aqui identificamos um ponto de tensão no projeto político que se constitui em Belém, o qual, em certa medida, responde a lógicas diversas: o socialismo e diversas pautas "não ocidentais", ou seja, fora do registro epistemológico e axiológico do mundo moderno. Retornaremos a isto mais à frente.

20 O I Encontro aconteceu em Chiapas, no México, em 1996, em meio a grande repercussão e visibilidade política dos zapatistas, indígenas insurgentes.
} 
capítulo 2

\section{Belém: o rio, a floresta, a cidade e seus povos - uma história em disputa}

Belém é hoje considerada cidade-sede ou porta para a Amazônia. Dado que essa centralidade política também se refere a uma disputa pública pelos sentidos da cidade (quiçá da região) e de seus sujeitos, podemos, a partir desse ponto de vista, questionar as formulações dicotômicas através das quais comumente se estabelece legibilidade e sentido aos processos na Amazônia. Com atenção a essa teia de relações, podemos considerar a dinâmica política dos movimentos urbanos, campesinos e ambientais como referente a um universo comum, enquanto um conjunto de relações não estranhas tampouco excludentes entre si, com formulações e agendas imediatas que se entrecruzam, embora guardem suas especificidades, como sujeitos políticos autônomos que são, com histórias e trajetórias próprias.

A par das múltiplas dimensões e camadas de sentido que podemos ler na atribuição dessa centralidade política à Belém (sua estrutura urbana e seu perfil populacional; sua localização geográfica na foz estendida do Rio Amazonas; seu papel, demonstrado no capítulo anterior, como uma das "cidades nó" na rede econômica e territorial montada na Amazônia), o fato de ser vista como "sede" da Amazônia parece acima de tudo se relacionar com o papel que a cidade desempenhou/desempenha frente à articulação política em torno da autonomia e soberania nacional, em defesa do patrimônio biológico, ambiental e cultural que a Floresta Amazônica representa. Belém é a capital de um estado como o Pará, entrecortado por tensões rurais: movimentos camponeses, dura repressão às formas de 
organização populares antilatifúndio, problemas com os madeireiros e mineradoras, embates constantes pela nova fronteira da soja e dos produtos transgênicos. Além disso, a Floresta Amazônica sofre um dos mais violentos processos de desmatamento e, em sendo a maior reserva de biodiversidade mundial, é palco de diversas formas de biopirataria ${ }^{1}$. Em volta dessa mesma floresta se articulam movimentos em sua defesa, e a partir da qual se intertecem as relações entre grupos, movimentos e diversos povos que a habitam se e as questões urbanas. Essa constelação de experiências se conecta com movimentos internacionais por direitos humanos, além de uma rede ampla, porém desconhecida, de movimentos de indígenas na América Latina ${ }^{2}$. A floresta, assim, deixa de ser vista e vivida como espaço idílico, intocado, reduto da natureza e da vida selvagem, para ser um palco singular onde se entretecem disputas na nova fronteira aberta para acumulação e reprodução do capital. Belém, nessa perspectiva, reverbera essas disputas, amplificando-as e agregando-lhes outras dimensões, estas urbanas e metropolitanas, mas profundamente informada por essas dinâmicas "não urbanas".

Com essa formulação, procuro sublinhar que a dinâmica dos movimentos sociais de/em Belém não se encerra nos limites administrativos dessa cidade, eles se conectam à questões, a movimentos sociais, a sujeitos e suas histórias. Essa constelação de experiências não necessariamente diz respeito ao seu universo direto de referências urbanas stricto senso, mas sim a uma dinâmica territorial integrada que, como demonstrado no capítulo anterior, é múltipla social e politicamente. Isto não significa subsumir as especificidades da luta, dos movimentos e das questões urbanas na cidade de Belém. Trata-se de atentar para o fato de que o universo rural e as questões ambientais, ancorados numa dinâmica econômica e social do campo, não se excluem, ao contrário, mantém uma forte relação de mútua determinação.

\footnotetext{
${ }^{1}$ Para uma discussão aprofundada, ver Laymert Garcia dos Santos (2003: 15-106).

${ }^{2}$ Parte desse debate que articula em torno da Floresta movimentos de resistência à ordem capitalista mundial, especialmente nesta sua fase chamada globalização, está registrada em Encontro Americano pela Humanidade e Contra o Neoliberalismo (2002).
} 
Hoje, passado quase um século do ciclo da borracha, a cidade de Belém é segunda ${ }^{3}$ maior cidade da região Norte do Brasil, com 1.393.399 habitantes em 2010 e 1.280 .614 habitantes em 2000. Segundo o IBGE, o município de Belém conforma com os municípios de Ananindeua, Marituba, Benevides e Santa Bárbara do Pará, a Região Metropolitana de Belém, com mais de 1,840 milhão de habitantes.

Tabela 4 - Evolução da população total da Região Metropolitana, 1991, 1996, 2000 e 2010

\begin{tabular}{|c|c|c|c|c|}
\hline Município & 1991 & 1996 & 2000 & 2010 \\
\hline Ananindeua & 88.151 & 341.257 & 392.947 & 471.980 \\
\hline Belém & 1.244 .689 & 1.144 .312 & 1.279 .861 & 1.393 .399 \\
\hline Benevides & 68.465 & 28.130 & 35.350 & 51.651 \\
\hline Marituba * & - & 49.239 & 75.448 & 108.246 \\
\hline Santa Bárbara do Pará ** & - & 11.549 & 11.375 & 17.141 \\
\hline
\end{tabular}

Fonte: Censo Demográfico, IBGE.

* Números desde 1996, quando Marituba tornou-se município.

** Números desde 1996, quando Santa Bárbara tornou-se município.

O Pará, segundo maior estado do país, com mais de 1,250 milhão $\mathrm{km}^{2}$ de território (corresponde a 14\% do território nacional), abriga parte da Amazônia brasileira (que tem mais de 5 milhões de $\mathrm{km}^{2}$ ), 1/5 da reserva de água doce mundial e, onde, apesar desses índices que atestam sua grandeza "natural", mais de 5 milhões de pessoas vivem em áreas urbanas, o que corresponde a 68\% da população total do estado. Esses números grandiosos equiparam-se ao número da população em estado de indigência4: cerca de 2 milhões de pessoas, ou seja, $40 \%$ da população paraense (na região Norte são 3,8 milhões, o que corresponde a $36 \%$ da sua população).

A pobreza e a pobreza extrema indicadas por esses números são visíveis na cidade de Belém. Os índices de urbanização e acesso a serviços de infraestrutura urbana denunciam o alto grau de segregação socioespacial vivida na cidade ${ }^{5}$. Assim, em Belém não apenas em

\footnotetext{
${ }^{3}$ Segundo dados do Censo Demográfico, do IBGE, o município de Manaus tem 1.802.014 habitantes em 2010, e tinha 1.405.835 habitantes em 2000.

${ }^{4}$ São considerados indigentes aqueles que vivem com U\$ 1,08 per capita familiar por dia, ou menos.

${ }^{5}$ Em 1997, para usar como referência o ano de posse do governo de Edmilson Rodrigues, o abastecimento por água tratada atingia a $70 \%$ dos residentes em Belém, assim como a coleta de lixo também tinha um índice bastante baixo de atendimento, em média $51 \%$ no município, com aumento nos distritos centrais. A coleta de esgoto atingia neste momento apenas $5 \%$ da população, os outros $95 \%$ dos dejetos eram lançados sem
} 
Belém se encontram face a face a memória do fausto de ciclos econômicos de crescimento e vastos territórios de pobreza e precariedade, mas estes se misturam: palacetes e casarões da antes opulenta Cidade Velha - prédios nos quais hoje a população pobre mora transformados em cortiços e ocupações, instalados em ruas pelas quais correm nas valas o esgoto a céu aberto.

A ocupação portuguesa no início do século XVII inaugurou a colonização/ocupação territorial da Amazônia, com a instalação do Forte do Presépio, hoje chamado Forte do Castelo, e a fundação da cidade de Santa Maria de Belém do Grão-Pará. Como sublinha Bolle, “a fundação de Belém, em 1616, no estuário do Rio Amazonas, se baseou numa razão de Estado que foi militar, política e econômica: construir um ponto estratégico de acesso, controle e exploração de toda a bacia amazônica" (2008: 99).

Depois desse "início" de ocupação territorial, ocorrida justamente onde existiam três aldeias tupinambás (cf. Simoniani, 2010), o crescimento de Santa Maria de Belém seguiu a geografia do lugar, marcada pelos rios, estendendo-se ao longo da baía do Guajará, na direção norte. Essa expansão conformou o chamado bairro da Campina, contíguo à Cidade Velha, que abriga o Forte do Castelo e as ruas iniciais do núcleo da ocupação portuguesa. “As primeiras ruas de Belém surgiram seguindo do Guamá e por ele se orientaram. Eram as ruas do Norte, Espírito Santo e dos Cavaleiros (estreitos caminhos), hoje, respectivamente, Rua Siqueira Mendes e Rua Dr. Assis e Dr. Malcher" (Pinheiro et al. 2007: 153).

A atividade econômica inicialmente introduzida pelos portugueses, como de resto em quase todo o território colonizado, foi a do cultivo de cana para produção de açúcar. Atividade esta que, dadas às condições naturais do sítio, rendeu pouco economicamente, e os engenhos reais logo se transformaram em "molinetes", pequenos engenhos produtores de aguardente que, naquele momento, tinha maior mercado.

Com o insucesso da lavoura da cana-de-açúcar, os colonizadores portugueses, especialmente os religiosos, com a ajuda dos índios (domesticados e aculturados, conhecedores dos rios e da floresta), estabeleceram a "coleta das drogas do sertão" (plantas medicinais e aromáticas, cacau, canela, cipós, raízes etc.), utilizando os rios como vias de

tratamento na rede de drenagem, afluindo diretamente para os rios e igarapés de Belém e para a Baía do Guajará, que banha a cidade. 
acesso, em cujas margens surgiram os primeiros povoados e vilas da região, a partir das missões, quartéis e fortalezas. A atividade da coleta se estendeu até os meados do século XIX e seus resultados materiais e econômicos foram escassos, salvo o relativo progresso que toda a Amazônia, especialmente o Pará, teve no governo do Primeiro Ministro português Marquês de Pombal (1750-77), durante o reinado de D. José I. Pombal criou a Companhia de Comércio do Grão-Pará, com sede na cidade de Belém, incentivando o cultivo do café, fumo, cacau e a pecuária, bem como ampliou a utilização da mão de obra escrava africana. (Pinheiro et al., 2007: 154).

A fase de expansão Companhia de Comércio estende-se até o final do governo pombalino, em 1777, e coincide com o fechamento da Companhia do Grão-Pará, inaugurando uma nova fase de estagnação econômica que somente na metade do século XIX será interrompido com o início do ciclo da borracha. Esta, inicialmente um dos produtos da exploração das "drogas do sertão", somente com o desenvolvimento técnico, na Europa, dos processos de vulcanização do látex, ganha lugar central na economia da região e se torna um elemento estruturador da dinâmica urbana desta, tanto social como territorialmente. Houve a instalação de diversos equipamentos e bens urbanos de uso coletivo que ajudaram substantivamente na constituição de uma cidade de feições europeias em plena Floresta Amazônica, a Belém da Belle Époque: bondes elétricos (cujos trilhos ainda vemos na cidade), “a iluminação pública, serviços de esgoto, limpeza urbana e forno crematório, corpo de bombeiros, calçamento de ruas e avenidas" (Pinheiro et al., 2007: 155), além da construção de diversos prédios, referências ainda hoje importantes para a imagem de Belém como um polo avançado de modernização econômica e cultural.

Nesse momento de expansão da borracha, também ocorre o que se chamou de “camponesação" da região bragantina: o surgimento e crescimento de núcleos agrícolas, incluindo em Ananindeua6 ${ }^{6}$ cujos produtos são matéria-prima para nascente indústria de transformação que se desenvolvia em Belém, com a instalação de fábricas de tecelagem,

\footnotetext{
${ }^{6}$ Importa dizer que até 1943, o município de Ananindeua pertencia a Belém, assim como Benevides - estes municípios depois de emancipados conformaram, na década de 1970 e, depois, na década de 1990, a Região Metropolitana de Belém.
} 
calçados, fumo, doces e refrigerantes e sabão. Essa produção agrícola, além de prover consumo local, abastecia Belém.

As nascentes indústrias instalaram-se no bairro do Reduto, área contígua ao bairro da Campina, em direção ao norte. Os bairros de Nazaré, Batista Campos e Umarizal concentravam os palacetes da elite belenense; áreas conservadas para fins estritamente residenciais, no que antes eram as "rocinhas" - um espaço de elite e de segregação socioespacial constitutiva da produção e lógica urbana de Belém.

Outra face dessa ocupação com ares modernos, a maior parte da população pobre de Belém - sem terras secas, urbanizadas e higienizadas - morava e ainda mora "no alagado"7, como se diz popularmente. A ocupação dessas baixadas, que data dos anos 1950, período durante o qual as "terras altas" disponíveis na cidade tornaram-se escassas ${ }^{8}$, está articulado com a consolidação da ocupação do centro da cidade e da relativa escassez de terras urbanizadas para expansão da malha urbana. É importante destacar que essa ocupação foi feita a custa do aterramento dos pequenos rios e igarapés, que cortam toda a cidade, o que deixou uma herança de depredação ambiental e situações de insalubridade, além de enchentes ou precárias condições de habitabilidade que persistem nessas áreas, basta considerarmos o pequeníssimo índice de coleta de esgoto da cidade até os dias atuais, que nem mesmo os ciclos de expansão econômica conseguiram melhorar.

Desse aterramento de áreas alagadas, surgem bairros ainda dentro da Primeira Légua patrimonial estabelecida na sua ocupação portuguesa inicial. Segundo Paracampo (1992), as baixadas somam $40 \%$ do território municipal, abrigam cerca de meio milhão de pessoas e correspondem a cincos bacias hidrográficas presentes naquele território: Una, Reduto, Armas, Comércio e Tuncunduba. Não é demais sublinhar que a ocupação dessas áreas foi feita pela população pobre da cidade e que, a partir dos conflitos fundiários presentes nestas, parte do movimento popular urbano de Belém se estruturará nas décadas de 1970 e 1980, sobretudo.

\footnotetext{
${ }^{7}$ Esses "alagados" são as áreas de cota igual ou inferior a 4 metros, que é a cota de alagamento dos rios, o que significa que são áreas de alagamento permanente ou que periodicamente alagam pelas cheias dos rios que banham e cortam a cidade.

${ }^{8}$ Importante lembrar que o município de Belém possui 39 ilhas. Essa porção insular corresponde a mais de $65 \%$ de seu território; a porção continental por sua vez é composta por 14 hidrográficas e tem atualmente uma taxa de urbanização próxima de 99\%.
} 
A expansão urbana de Belém na década de 1960 foi marcada por um processo de periferização, à semelhança do que aconteceu em outras cidades paraenses. Expansão esta impulsionada pela construção da rodovia Belém-Brasília e a consequente facilitação do deslocamento de grande contingente populacional no estado em busca de empregos e novas frentes de trabalho, fruto de uma maior integração da região com as áreas de intensa produção industrial que vinha combinada com políticas de desenvolvimento econômico para a Amazônia. Na contramão desse crescimento econômico estadual, Belém, neste período, viverá outro ciclo de declínio da produção industrial, até então fomentada em parte pela dificuldade de acesso aos centros produtores de industrializados, notadamente $o$ Centro-sul, o que colocava a cidade como um dos poucos centros industriais na região Norte.

A consolidação de um padrão de crescimento urbano periférico levará no final do século XX, nas décadas de 1980 e 1990, à conurbação de Belém com as cidades da região metropolitana, especialmente, aquelas que lhe fazem divisa e que foram, até pouco tempo antes, seus distritos: Ananindeua, Marituba e Benevides.

A disposição cronológica desses ciclos econômicos, das fases de expansão urbana e de espraiamento dos limites da cidade, da instalação dos monumentos, dos grandes equipamentos de cultura e das marcações urbanas em Belém monta uma cena cujo tom parece ser o de uma sucessão entre ciclos de bonança (com sua correlata expansão urbana e modernização da cidade) e ciclos de decadência (com rebatimentos diretos na organização urbana de Belém). Essa sucessão, entretanto, se olhada de outra perspectiva, pode revelar nas ruínas do apogeu econômico, o atual descuido da sua ocupação não moderna, não opulenta, marcadamente característica das áreas pobres da cidade. Willi Bolle (2008) desconstrói essa bem-arrumada tese de um movimento cíclico e dicotômico de desenvolvimento e decadência.

No artigo acima citado, Bolle nos convida a um passeio por Belém desde o centro da cidade, a Cidade Velha, através de seus ícones, seguindo de perto Belém do Grão-Pará narrada por Dalcídio Jurandir. Através de uma história topográfica de Belém, mira "os ícones urbanos como repositórios da história da cidade" (Bolle, 2008: 101) e revela os movimentos constitutivos dessa ordem aparentemente contraditória que guarda, no 
mesmo espaço, os signos da opulência e da modernização e os traços persistentes da pobreza e da deterioração.

O incômodo com a decadência é próprio da forma como a cidade se produz, marcando os lugares e as formas de visibilidade das diferenças ao padrão dominantes, assim como o acesso (concreto e simbólico) aos bens e espaços produzidos nela. Esse incômodo, nomeado de formas diversas - atraso e decadência são os mais fortes e comuns -, é a regra e não uma exceção na história e no conjunto das referências que informam a visão dessa cidade.

Lendo a cidade a partir de seus ícones e extraindo dela sua história apagada, a argumentação do autor caminha no sentido de demonstrar como estão dispostas na cidade, nas suas marcas e na vida social que lhe constituem "contradições da modernização: ela representa ao mesmo tempo o progresso e a deterioração” (Bolle, 2008: 107 [grifos no original]). E segue mais a frente provocando o debate:

Como escrever a história de Belém durante os últimos cem anos? Como uma sequencia de modernizações - a primeira por volta de 1900, apenas interrompida por um tempo de declínio, mas retomada, a partir da década de 60, de modo mais efetivo e duradouro - ou como uma época de desenvolvimento precário? (Bolle, 2008: 107-8 [grifos no original]).

Apesar de indicá-la rapidamente, Bolle nos dá a chave de compreensão de quão conflitiva é a nomeação de Belém como porta para a Amazônia. Ligada à relação tensa entre as formas de compreensão do papel da cidade, trata-se de uma disputa de classe pelo sentido do que significa essa nomeação. Essa disputa pelo controle da cidade, de suas visuais e de seus acessos ao rio, ainda que, por exemplo, apenas tomados como objetos de contemplação para a elite belenense, configura-se assim como um processo de disputa pela partilha do sensível, nos termos de Rancière.

\section{Cidade em disputa: os movimentos sociais em Belém}

Como disse anteriormente, a constituição de um movimento popular organizado com as ocupações das baixadas de Belém nas décadas de 1960 e 1970, inicia-se com a 
resistência e o confronto à política de remoção da população pobre dessas áreas da região central da cidade. Especialmente depois de 1975, os conflitos pela posse de terra se acirrarão nos bairros da Sacramenta, Pedreira, Jurunas, Cremação, Guamá, Terra Firme, Marco, Canudos e Jabatiteua (Malato, 2006). As ocupações em áreas de baixadas era o expediente mais comum de resolução da questão habitacional pelas camadas populares, dado que, naquele momento, a política habitacional na cidade respondia precariamente à demanda de crescimento e expansão de Belém.

Surgem, então, nesses subespaços, movimentos populares, mobilizações, manifestações mais radicais, atos públicos, manifestos de todos os tipos. As principais reivindicações foram por urbanização, equipamentos coletivos e regularização fundiária. Dentro do município de Belém, os conflitos fundiários em torno da luta pela propriedade das áreas ocupadas sempre foi intensa. Ocupou-se um grande número de áreas alagadas: públicas e de particulares, da Igreja, principalmente áreas da Marinha e da Universidade Federal. As baixadas surgem como alternativa de moradia da população de baixa renda. Atingem uma extensão de 39,21\% do município de Belém, com densidade demográfica de 159,51 (hab/ha), envolvendo uma população total de 765,476 habitantes(Pinheiro et al., 2007: 159).

Nesses espaços de segregação, nascerá a organização dos movimentos de moradia e populares em Belém.

As baixadas ou terras alagáveis abrangem praticamente todo o sítio urbano da cidade de Belém. Apresentam uma tipologia originalmente bastante segregada, grande densidade demográfica com base na autoconstrução de moradias (tipo palafitas) em terrenos públicos e/ou impróprias para ocupação edificada. São 28 canais que cortam a cidade de Belém, representando o primeiro vetor de periferização das camadas mais pobres da população. 0 saneamento básico é a principal carência desta área (Pinheiro et al., 2007: 160).

Assim como em outras cidades brasileiras, em Belém surgirá do encontro das aspirações populares e das formas de trabalho político de base de organizações da igreja 
católica, as Comunidades Eclesiais de Base (CEB's); das organizações da sociedade civil que lutavam contra o regime militar, os movimentos sociais urbanos. A dinâmica de aparecimento e fortalecimento destes últimos, chamados de movimento de bairros, responde assim a várias dimensões: uma local/municipal, diretamente relacionada à dinâmica e aos conflitos naquele território, assim como ao conjunto mais geral de questões, conflitos urbanos e de políticas públicas. Por outro lado, as lutas que deram origem aos movimentos de bairros acontecem num momento de grande efervescência política no país, de reorganização dos movimentos sociais contra a ditadura militar e pela reivindicação de um novo modelo de gestão pública e democrática. Elementos que não passaram ao largo da organização social em Belém, assim, para além da posse da terra, esses movimentos de bairros articularam lutas para melhorias e serviços urbanos.

Importa sublinhar que a migração da população rural do estado do Pará para cidade de Belém intensifica-se em meados da década de 1980 com a introdução dos chamados Grandes Projetos, intervenções em larga escala no setor de geração de energia hidroelétrica e no setor mineroextrativista. Essa migração mais recente do campo para a cidade segue o fluxo migratório desencadeado pela abertura da rodovia Belém-Brasília. A população migrante recém-chegada à Belém, antes e agora nos anos 1980, ocupará o alagado, o que em certa medida pressionará mais ainda as já precárias condições de acesso à moradia e à infraestrutura da cidade, engrossando o caldo de mobilizações e lutas pela posse da terra bem como espraiando suas reivindicações para outros campos correlatos, especialmente a luta por serviços e bens urbanos.

E aí na sequência [das ocupações e das lutas pela posse da terra, surge] o movimento pela água, pela energia elétrica, o movimento pela construção de equipamentos públicos, escola, posto de saúde, uma sequência, digamos assim, de lutas sociais, de movimentos vivos na cidade mostrando a cara. Isso foi concomitante também ao surgimento e à concretização do Partido dos Trabalhadores, aqui na cidade, né, a Central Única dos Trabalhadores. Impulso igual ao restante do país que teve movimento sindical nesse período também. Então a década de 1980, o início da década 1980 [...] foi 
marcado por esse forte movimento. (Marinor Brito ${ }^{9}$, entrevista concedida à pesquisadora, 31 de julho de 2009)

Olinda Malato (2006) chama atenção para o fato de que a montagem de um aparato estatal para intervenção urbana de Belém foi um fator importante de tensão entre as comunidades e associações nas áreas de baixadas e o poder público municipal. A organização das comunidades de bairros e associações de moradores teriam sido, nessa perspectiva, também uma forma de reação organizada das camadas pobres moradores das baixadas a esse tipo de intervenção. Sob a justificativa de sanear as áreas dos alagados e melhorar a condição de moradia da população, algumas das ações do poder público municipal resultaram na remoção de famílias dessas áreas centrais, que foram entregues posteriormente ao mercado imobiliário, como é o caso da área do Canal da Doca, cuja desocupação data da década de 1970 e hoje é uma das regiões mais valorizadas de Belém.

$\mathrm{Na}$ constituição das organizações populares e de base em Belém, tiveram papel fundamental, além das CEB's, as entidades Federação de órgãos de Assistência Social e Educacional (Fase) e Sociedade Paraense em Defesa dos Direitos Humanos (SPDDH), atuando no sentido de mobilizar e organizar os moradores dessas áreas. Nesse caldo de mobilizações, surgirão também as duas entidades mais representativas dos movimentos urbanos em Belém do final da década de 1970 e começo dos 1980, a Comissão de Bairros de Belém (CBB) e a Federação Metropolitana de Centros Comunitários e Associações de Moradores (Femecam).

Em 1978, com a finalidade de coordenar as mobilizações nos diferentes bairros de Belém nasceu o Movimento Casa Própria. No início do ano seguinte, numa assembleia convocada pelo SPDDH e realizada no salão da paróquia da igreja Nossa Senhora de Lourdes (bairro da Pedreira), para discutir os conflitos pela posse da terra na capital, fundou-se a Comissão de Bairros Pobres de Belém, que poucos meses depois passou a denominar-se Comissão de Bairros de Belém (Petit, 1996: 60).

\footnotetext{
${ }^{9}$ Marinor Brito foi vereadora de Belém por três legislaturas consecutivas (1997-2000 e 2001-2004 pelo PT Partido dos Trabalhadores e 2005-2008, pelo PSOL - Partido Socialismo e Liberdade), sendo as duas primeiras nas gestões de Edmilson Rodrigues (1997-2004).
} 
A CBB se tornará a maior interlocutora do movimento popular no campo do direito à moradia com os governos democráticos do período pós-ditatorial, e será ao lado de outras entidades e grupamentos fundadora do Partido dos Trabalhadores no final da década de 1980. Junto com a CBB, estava a Fase (e seus escritórios urbanos e rurais), a SPDDH, militantes do PCdoB e do PMDB, setores da Igreja Católica progressista, os professores secundarista do Pará, organizados na Associação dos Professores do Estado do Pará (Apepa), os docentes da Universidade Federal do Pará e estudantes dirigentes de centros acadêmicos. Essa composição, em certa medida, ajuda a compreender a base de apoio e o diálogo estreito com estes setores no decurso das administrações de Edmilson Rodrigues, na cidade de Belém, entre 1997 e 2004.

\section{Eleição de 1996: história subterrânea ou raio em céu azul?}

À primeira vista, a eleição de Edmilson Rodrigues foi uma surpresa na e para a cidade de Belém, como nos informam os vários setores procurados, desde o chefe de gabinete do prefeito até representantes de ONGs que acompanharam a gestão municipal ao lado dos movimentos sociais belenenses. Todos marcam a novidade e a surpresa que foi a eleição de uma proposta como aquela diante de um cenário muito conservador que se perpetuava na cidade e no estado do Pará como um todo. Entretanto, essa surpresa se matiza à medida que os interlocutores descrevem as condições objetivas da disputa política e eleitoral; o que faz pensar o que quer dizer esta primeira nota de surpresa que se mantêm na memória dos entrevistados.

Essa surpresa parece dialogar com uma visada histórica de longa duração, de compreensão dos movimentos sociais na cidade, sua história e as formas de sociabilidade política em Belém (e no Pará) e ao mesmo tempo dirigir-se a aspectos imediatos da conjuntura político-eleitoral daquele momento. Os entrevistados parecem marcar, quando falam da escolha de um projeto político claramente de esquerda para o governo da cidade, a diferença desses anos de governo e da experiência política que dela surge em relação à 
história e às formas de sociabilidade política em Belém ${ }^{10}$. "Bem, a vitória eleitoral em 1996, ela foi um fato extraordinário e imprevisto também, digamos assim" (Aldenor Araújo Jr, entrevista concedida à pesquisadora, 02 de dezembro de 2009).

A eleição mostra-se ainda como uma surpresa se tomamos em conta que, no plano nacional, o ano de 1996 foi o pior resultado eleitoral que o PT já enfrentara desde os anos 1980, em pleno primeiro mandato de FHC, embalado pelo sucesso do Plano Real e pela alta popularidade do governo federal que impactou o cenário das administrações municipais. A eleição em Belém estava na contramão da tendência nacional para o Partido dos Trabalhadores, de perda de espaços institucionais. Mesmo entre os seus partidários e parceiros próximos, a eleição da Frente Popular em Belém parecia uma possibilidade ainda bastante longínqua, dada a história de dominação política dos grandes partidos e setores conservadores, representantes das oligarquias paraenses na cidade.

Partindo de um patamar que variava entre três e quatro pontos percentuais nas pesquisas eleitorais, a candidatura de Edmilson Rodrigues internamente ao seu partido congregava forças daquilo que poderia se chamar esquerda do PT, agremiando tendências e grupos que se reivindicavam comunistas ou socialistas e que não eram os setores majoritários dentro na estrutura partidária, considerada sua distribuição nacional de forças políticas. No Pará, entretanto, o grupamento político do futuro prefeito, a então Força Socialista, tinha grande participação e representação no partido, assim como incidência e direção política em movimentos sociais e sindicais importantes na cidade, tais como o Sindicato dos Trabalhadores em Educação Pública do Pará (SINTEPP) e os movimentos comunitários e/ou de moradia.

Um elemento importante nesse contexto eleitoral é a relativa desarticulação do campo conservador de Belém, que, naquele momento, não tinha com um candidato de consenso e cujas principais lideranças e expressões eleitorais encontravam-se em polarização dentro do seu próprio campo, não tendo assim quem unificasse seu discurso e, consequentemente, concentrasse votos. 0 prefeito antecessor de Edmilson Rodrigues, Helio Gueiros, então no

\footnotetext{
${ }^{10}$ Neste sentido, é possível pensar a gestão do autointitulado Governo do Povo como uma fratura, uma fresta por onde se pode vislumbrar a possibilidade de construção política de corte abertamente popular em confronto com a ordem vigente, o brilho de uma experiência política que rompe a lógica da governabilidade tecnocrática, mas que se apaga frente à dominação e as impossibilidades de sua própria gênese. É uma parte do processo.
} 
PFL, deixava o governo municipal com índice de aprovação em torno de 60\%, mas não tinha um nome forte para sua sucessão. Em sua oposição, ainda que dentro do mesmo campo, estava Elcione Barbalho, ex-mulher de Jarbas Barbalho, com muita ascendência no grupo político deste.

Aliado a isto, os entrevistados fazem referência uma "história subterrânea" das lutas populares que tinham maior expressão nos movimentos de moradia, dos professores e estudantil, que vinham de um passado recente de mobilização, como procuramos demonstrar acima, e que se engajaram aos poucos na campanha de 1996.

Porque os movimentos sociais aqui que foram organizados, digamos assim, teve o fervor da organização na segunda metade da década de 1960, não encontravam os espaços de decisão, de negociação, de participação. Então sempre foi no embate com os governos autoritários. Uma das coisas que o movimento levantava desde então é que pudesse haver uma maior participação e democratização da política urbana. Porque já tinha uma história do movimento da reforma sanitária, do pessoal da saúde, da descentralização e da municipalização do sistema de saúde. Já existia também todo um acúmulo no debate da educação. 0 movimento da reforma urbana também se articula pra que se constituíssem os sistemas das cidades e aí vem toda luta pela inclusão da política urbana, constituição, pela elaboração do estatuto da cidade e todas essas demandas e essas conquistas, elas estão atravessada por um dos pontos do IDH e reforma urbana que é gestão democrática. Então vem de muito tempo essa luta, com manifestações, com caravanas que iam pra Brasília, né? E enfim as emendas da constituição, depois as constituições estaduais e as leis orgânicas; na própria elaboração dos planos diretores também esse debate da gestão democrática foi colocado, foi constituído no plano diretor de Belém, no sistema de gestão de planejamento e gestão democrática. (João Gomes ${ }^{11}$, entrevista concedida à pesquisadora, 4 de dezembro de 2009)

\footnotetext{
11 João Gomes é historiador e coordenador do Núcleo Cidadania da entidade Fase Amazônia, foi representante do segmento ONGs no Conselho da Cidade.
} 
É possível dizer assim que a eleição de Edmilson Rodrigues não é um ato espontâneo nem inexorável, não é um raio em céu azul, como parece à primeira vista. A vitória do PT na eleição municipal parece ser mais uma construção de longo prazo, fruto do enraizamento desses setores nos movimentos sociais e sindicais, ainda que não estivesse espraiado entre amplos setores populares e sim concentrado em setores organizados específicos que deram sustentação à campanha; num primeiro momento, através dos dirigentes das organizações populares e sindicais e, somente depois de iniciada a campanha propriamente, espraiou-se para as bases desses movimentos e de outros setores não organizados. Além disto, é preciso ter em conta que o futuro prefeito e seu grupo político tinham desde algum tempo, expressão eleitoral significativa no cenário paraense, ocupando assentos na Assembleia Legislativa e em Câmaras Municipais no estado do Pará.

A fala que melhor condensa esse grupamento de fatores é justamente de um militante de movimentos sociais de moradia, assessor da ONG Fase Amazônia, reconhecida por seu trabalho de assessoramento aos movimentos populares.

Mas foi uma soma de fatores que levou com que o Edmilson pudesse chegar à prefeitura. No decorrer da campanha a militância se dedicou e começou a acreditar porque [...] houve um problema muito grande quando os dois principais contendores começaram uma disputa e uma briga muito acirrada [sobre quem é] mais ladrão que o outro, quem mais roubou, quem mais isso, quem mais aquilo... E acabou o Edmilson navegou numa onda que cresceu e levou ele pras cabeças. E a partir daí a campanha pegou fogo porque a militância mesmo abraçou. Por que eu tô dizendo isso? Porque então, o programa de governo não era um programa completamente estruturado. [...] Logicamente, ninguém entra numa campanha apenas pra fazer bonito, a perspectiva é, lógico, ganhar. Mas as condições no início: o Edmilson partiu com 3\% de intenção de votos. Então, no começo da campanha, a maior parte da militância, pode-se dizer assim, não acreditava efetivamente... E o programa, no meu ponto de vista, não estava estruturado para o exercício realmente dessa parcela do poder que é a prefeitura. Mas de todo modo, já vinha, no caso da participação, já estavam sendo colocados alguns elementos importantes com relação a isso, da expectativa de democratização, [...] da inversão de prioridades e a questão da participação 
que era colocado como modo petista de governar, isso estava colocado, mesmo que em alguns casos, muito em linhas gerais, mas estavam colocados. Acaba que era um principio geral do PT. Então, isso se revelou no programa de governo. Agora, efetivamente só depois do governo é que [se pensou] como é que nós vamos fazer isso. Porque não se tinha muito claro já como executar, não tinha nenhuma experiência anterior em Belém e as disputas internas [eram] muito acirradas. Então foi um início conturbado, mas foi bastante interessante. Já no primeiro ano, já teve milhares de pessoas já começaram participar efetivamente das atividades (Guilherme Carvalho $^{12}$, entrevista concedida à pesquisadora, 4 de dezembro de 2009).

Esta fala nos chama atenção para um aspecto bastante importante: o lugar que as formas de gestão participativa tinham no programa de governo. Se é possível dizer que o Orçamento Participativo (OP) era um instrumento consagrado, já naquela época, em outras administrações petistas e que constava como diretriz partidária central, não estava dado como ou quando este seria introduzido na cidade. Isto faz diferença à medida que sua implantação em Belém, então, deve responder a um conjunto de demandas, ao mesmo tempo referidas ao seu campo político mais amplo e específico da própria cidade. Por um lado, integra-se à fortuna crítica petista à gestão antidemocrática das cidades e, por outro, responde a demandas políticas e institucionais concretas e específicas de Belém que foram se constituindo ao longo da campanha, com a incorporação de setores populares e que estavam expressas na ideia de transformação e mudança. Não se pode deixar de dizer que as respostas a essas demandas foram condicionadas pelo projeto político que estava esboçado no plano de governo para Belém, que tem algumas diferenças em relação aos programas políticos petistas daquele período.

Deste mecanismo de gestão em Belém nos ocuparemos no capítulo seguinte.

\footnotetext{
12 Guilherme Carvalho é técnico educador da ONG Fase Amazônia e, junto com João Gomes, coordenador da Fase Amazônia, concedeu esta entrevista em Belém, no dia 4 de dezembro de 2009. Ambos estiveram envolvidos com o OP e com o Congresso, sendo eleitos delegados ao Conselho da Cidade.
} 
capítulo 3

\section{O Orçamento Participativo em Belém (1997-2000)}

\section{Uma questão e seu campo de discussão}

As relações entre cidade e política, ao longo da década de 1990, alteraram-se profundamente. Este parece ser um ponto de partida comum, na produção sociológica desde a metade dos anos 1990, a várias e distintas formas de apreensão, leitura e análise da realidade brasileira atual e, sobretudo, das formas de compreensão da vida urbana e da participação política que se seguiu à chamada redemocratização brasileira, a partir de 1985.

A problematização da vida pública brasileira e seus impasses encontrou, nos anos 1980, seu centro no aparecimento de novos sujeitos políticos ou novos personagens, usando expressão célebre cunhada por Eder Sader (1988), servindo de inspiração para uma profícua discussão nos anos 1980 e nos 1990. Essas leituras do cenário brasileiro ao mesmo tempo que analisavam a cena pública da época, "acertavam as contas" com a história da formação brasileira, relendo e problematizando as figurações e entendimento da formação, do papel e das maneiras de aparecimento e atuação políticos das classes populares no cenário público, lidos até ali na chave da incompletude e da impossibilidade de acesso à cidadania, aos direitos sociais e à vida pública ${ }^{1}$.

\footnotetext{
${ }^{1}$ Sobre essa discussão, ver Paoli $(1986,1987)$, Sader (1988) e Telles (1999) que problematizam a visão das ciências humanas das classes trabalhadoras no Brasil na chave da incompletude. É importante dizer também que a tradição de análise vinda não da sociologia, mas do serviço social da PUC-SP, é significativa neste momento e em certa medida, dialogou com estes autores. Ver especialmente Sposati (1988) que problematizam os serviços/programas de assistência social na chave dos direitos sociais e não mais da filantropia.
} 
O que ali se colocavam em questão os próprios vínculos entre cidade e política, iluminando a experiência política dos trabalhadores para além dos seus locais de trabalho, privilegiando-se a leitura dos seus locais de sociabilidade e suas formas de vida. Assim, no campo da teoria sociológica, ultrapassava-se a concepção estrita dos trabalhadores como meros operários, rejeitando-se a herança ortodoxa do marxismo althusseriano. Por outro lado, no campo das práticas sociais, viu-se um "arejamento" das formas de organização dos trabalhadores, fundado na crítica à trajetória dos partidos de esquerda centralizados e na procura de uma organização mais horizontal dos "de baixo"2.

Nesse encontro entre as práticas populares e as novas interpretações acadêmicas de sua trajetória ${ }^{3}$, situa-se o nascimento de experiências de democratização dos espaços de decisão política sobre a coisa pública. Ali mesmo se refaziam as relações entre cidade e política, tanto nos marcos da literatura quanto da própria experiência concreta dos movimentos sociais.

Neste sentido, a Constituinte de 1988 é um momento importante, uma vez que representou um novo marco jurídico que, em alguma medida, representava os anseios e expectativas de uma sociedade democrática, instituindo mecanismos e formas de participação popular e social na vida política do Brasil, recém-saído da ditadura militar, para além da democracia representativa. A importância da Constituinte também reside no fato de que, a partir deste novo arcabouço jurídico-legal, formas de participação popular foram reconhecidas, ao menos formalmente, como justas e abriram caminho para afirmarse como uma prática de gestão compartilhada das políticas públicas, dos programas sociais e dos recursos concernidos nessa disputa. A inscrição desses mecanismos no corpo da lei constitucional é uma importante vitória dos movimentos sociais, sindicais e populares e, sendo resultado de lutas, com avanços e derrotas desses segmentos, serviu como referência na disputa pelos rumos da democratização brasileira ao longo dos anos 1990.

A consolidação dessas novas formas de participação popular - câmaras setoriais, fóruns de negociação, conselhos gestores de políticas públicas - na vida política brasileira,

\footnotetext{
${ }^{2}$ A expressão é de Florestan Fernandes.

${ }^{3}$ É importante salientar que as leituras sobre esse período, ainda que tenham algo em comum, apoiando-se em uma reflexão crítica sobre a caracterização dos trabalhadores e das classes populares brasileiros na chave da falta, da incompletude e da impossibilidade, não são homogêneas e nem se filiam à mesma tradição teórica. Importa apontar que, para além das diferenças de entendimento e de consequências de suas leituras, trata-se de um momento de revisão dos marcos teóricos de análise e de profunda inovação nas ciências sociais.
} 
entretanto, ocorreu concomitantemente às transformações pelas quais passou a economia mundial e a forma específica como o capitalismo se reorganizou (e ainda o faz) na periferia do mundo e no Brasil, sob a insígnia de globalização ou do neoliberalismo. Essa concomitância, como é possível perceber em diversos estudos sobre o tema, teve impacto não desprezível sobre as formas de organização da vida política do país e, especialmente, sobre as possibilidades de realização das promessas de democratização e emancipação concernidas nestas. É possível perceber os impactos dessas transformações em diversas dimensões da vida social, seja na organização da produção (nos locais de trabalho e na organização sindical), seja na cidade (na gestão urbana e nas suas formas de regulação, ou na falta dela), seja no aparecimento e consolidação de novos espaços de discussão de temas e questões até então postos à margem da vida pública brasileira.

Olhados agora em perspectiva, as novas formas de participação apresentam-se como uma experiência bifronte. Resultado do acúmulo popular que emergiu com força nos anos 1980, essas formas de democratização do Estado e da vida política brasileira herdaram nos anos 1990, em certa medida, as "energias utópicas" de construção dos mecanismos de partilha de poder entre Estado e sociedade da década anterior. Contudo, essa experiência se realiza sobre um solo movediço de remodelação da economia brasileira e também da vida política e social. 0 nó naquele período (que se estende e transforma até os anos que seguem) parece ser justamente a constituição espaços de debate e deliberação pública esperava-se a consolidação de uma experiência democrática -, num cenário de intensa privatização da vida e de redução de horizontes públicos ${ }^{4}$. Parece um contrassenso, mas não é: tudo se passa como se a política fosse desnecessária, ou, nas palavras de Oliveira, constitui-se "uma experiência subjetiva de desnecessidade, aparente, do público" (1999: 57), que, a bem da verdade, encobre o movimento real de constituição de formas, naquele momento necessárias a reprodução do capital, com o embaralhamento entre estado e mercado, que deslegitima a fala dissensual e anula a possibilidade de conflito (cf. Rancière, 1996).

\footnotetext{
${ }^{4}$ É paradigmático dessa leitura dos anos 1990, à qual me filio, Oliveira (1999), que citarei logo a seguir. De lá pra cá, uma vasta produção tem se debruçado sobre essa experiência, recortando de diferentes modos as experiências de redução do horizonte público/político da vida do cenário brasileiro, em especial nas cidades. Recente publicação coordenada por Rizek, Telles, Georges e Cabanes (2011), fruto de pesquisas na periferia paulistana, dá mostras deste encapsulamento privado que avança nas cidades brasileiras e que naturaliza as formas não públicas de experiência social.
} 
A produção acadêmica ${ }^{5}$ sobre os conselhos setoriais e as práticas de participação popular na administração pública, notadamente os orçamentos participativos, fornecem algumas pistas importantes sobre os eixos de interrogação privilegiados nesse processo, além de armar uma constelação de temas e de questões que foram postos em debate ao longo dos anos 1990. Sem dúvida alguma, a relação Estado/sociedade civil parece ser o centro articulador e irradiador dos questionamentos desses estudos, problematizado sob a ótica da cultura política (Avritzer, 1994; Dagnino, 1994, Baierle, 2000) 6 .

A compreensão dos anos 1990 e das novas relações entre Estado e sociedade civil estava, em certa medida, impregnada de esperanças e da aposta de que desse "encontro" (cf. Dagnino, 1994) a questão democrática no Brasil fosse problematizada de maneira diferente, assim como de que os processos reais de questionamento das formas autoritárias presentes no aparelho estatal e também na sociabilidade e práticas políticas, possibilitassem a abertura de espaços à participação societária na gestão pública e fomentassem a constituição de espaços públicos de reconhecimento das demandas legítimas que partiam da sociedade civil organizada, consolidando uma nova cultura política e uma cidadania renovada. Necessário dizer que essas análises (e também as apostas) não se furtaram à crítica dos limites e das contradições reais dos processos de implantação de orçamentos participativos, de conselhos gestores e dos mecanismos de controle social sobre a máquina pública; do aparecimento e do papel das ONG's e sua relação com os movimentos sociais; da instituição e institucionalização dos chamados "espaços de encontro" entre sociedade e Estado dos quais supostamente emergiriam novas práticas democráticas, a partir de um novo aprendizado da democracia.

\footnotetext{
${ }^{5}$ O grupo de pesquisa de Evelina Dagnino, na Unicamp, tem investigado de forma sistemática o funcionamento desses mecanismos de democratização da gestão pública, através dos conselhos e fóruns instaurados durante os anos 1990. A produção do grupo, ainda que sediada no departamento de Ciência Política, tem servido de importante interlocutor e mesmo de marco teórico para os estudos sociológicos sobre movimentos sociais e participação popular. Outro polo importante cuja produção é referência importante para o debate sobre democracia e participação popular especialmente nos anos pós-ditadura, situa-se na UFMG, sob coordenação de Leonardo Avritzer.

${ }^{6}$ A produção mais recente do grupo de pesquisa de Evelina Dagnino tem demonstrado algumas diferenças e novas perspectivas de análise dos processos de participação popular. 0 texto introdutório do volume $A$ disputa pela construção democrática na América Latina, organizado por Dagnino, Olvera e Panfichi (2006), retoma criticamente as abordagens da democracia e da sociedade civil e demarca claramente os novos eixos de interrogação e problematização desta temática.
} 
O cenário político dos anos 1990, ou uma das faces dos "anos bifrontes", agrega um elemento importante ao debate sobre a questão democrática brasileira: o desmanche neoliberal (Schwarz, 1999), momento do encolhimento das políticas públicas universais e da regulação estatal como elemento fundamental para manutenção de uma ordem social onde ainda fosse possível a dimensão de disputa pública e política.

A discussão sobre os impasses dos movimentos sociais e sindicais, as maneiras de desconstrução de sua representação política e as consequências para a vida pública no Brasil comparecem de maneira pouco expressiva no viés teórico de problematização que se debruça sobre as formas participativas de gestão pública - o que pode indicar já uma questão em aberto. Um exemplo na contramão dessa tendência na literatura é o artigo de "Sociedade Civil, Espaços Públicos e a Construção Democrática no Brasil: Limites e Possibilidades", no qual a autora problematiza as experiências de conselhos e dos espaços públicos para gestão participativa e da atuação das $0 \mathrm{NG}^{\prime}$ 's em nome dos movimentos sociais, chamando atenção para os impasses com os quais se deparam os "atores" envolvidos:

Sua centralidade [da complementaridade instrumental entre propósitos do Estado e da sociedade civil] se relaciona com o fato de que ela tem se construído nos últimos anos como uma estratégia do Estado para a implantação do ajuste neoliberal que exige o encolhimento das suas responsabilidades sociais. Nesse sentido, ela faz parte de um campo marcado por uma confluência perversa entre um projeto participatório, construído, a partir dos anos 80, ao redor da extensão da cidadania e do aprofundamento da democracia, e o projeto de um Estado mínimo se que isenta progressivamente do seu papel de garantidor de direitos. (Dagnino, 2002: 288-289 [grifos no original]).

Se, por um lado, essa produção que se debruçou sobre a experiência dos movimentos sociais e dos frutos nascidos do questionamento das formas de sociabilidade política brasileira colocava acento e armava a discussão partindo da noção de direitos sociais e do aprendizado político que a sua reivindicação e as formas de organização comunitárias fomentavam, é preciso sublinhar que, naquele mesmo período, teve lugar no Brasil aquilo 
que podemos chamar de acantonamento dos movimentos social e sindical, cujo paradigma de silenciamento é a greve dos petroleiros em 1995 (Miagusko, 2001). É importante notar, também naquele período, a consolidação do Movimento dos Trabalhadores Sem-Terra (MST) no cenário brasileiro como importante expressão dos trabalhadores rurais, cuja pauta, partindo das demandas específicas, procurou extrapolar o circuito das questões da produção agrícola. De certa maneira, o MST constituiu-se como polo de atração e tensionamento da esquerda brasileira e latino-americana - e, portanto, também para os movimentos sociais urbanos-, justamente no período de crise e fragmentação desse campo político. Outro ponto de destaque e de polarização do debate, com pouca projeção nesses conflitos, já tratado nos capítulos anteriores, diz respeito à configuração das causas ambientais e de povos tradicionais e/ou originários como questão política.

A produção acadêmica sobre as transformações econômicas e políticas que ocorreram durante os anos 1990 e seu impacto no Brasil, sobre as disputas pelo fundo público, a perda da capacidade de regulação do Estado, apontou como resultado desse processo a "desnecessidade do público" (Oliveira, 1999) e da política. Além disso, trouxeram ao debate a interrogação sobre as possibilidades e os limites desses novos "encontros democratizantes", uma vez que o solo mesmo onde essas experiências se enraizavam não constituía mais a possibilidade de disputa pública e, em última instância, da própria política. É curioso ver que justamente a gestão das precariedades e a pobreza crescente no Brasil nos anos 1990 - o ponto cego na literatura sobre os movimentos sociais - aparece aqui como o elemento que possibilita um questionamento mais profundo às virtuosidades aparentemente presentes nesses "encontros" entre sociedade civil e Estado.

Colocando em outros termos, a constatação de que nesse solo histórico de profunda mudança na base econômica brasileira (o que significou o aumento dos índices de desemprego, a desresponsabilização do Estado pelas políticas sociais de cunho universalizante, a falta de regulação pública/estatal da economia, a inexistência de barreiras e anteparos ao reificado mercado e a financeirização da economia) que se funda a experiência de gestão participativa e de uma prática política pretensamente democrática. Isto nos exige questionar se esses mesmos mecanismos nos quais se apostou não acabaram por funcionar como seu avesso: mostrando-se não como instrumentos políticos inovadores, e sim, como meios de gestão de precariedades da vida dos trabalhadores e dos mais pobres. 
Se o acento da produção da acadêmica sobre os movimentos sociais estava na ideia de que esses novos "encontros" pudessem (e puderam de alguma maneira) servir como uma espécie de "pedagogia" da democracia e dos jogos de procedimentos desta, parece que, em certa medida, esse aprendizado corroeu a possibilidade mesma de aparecimento do conflito e de questionamento da herança autoritária que queríamos superar. 0 procedimento anulou o conflito. Resiste como enigma não decifrado a gestão dos recursos públicos para a introdução e ampliação das políticas públicas, sobretudo aquelas "definidas" pelos orçamentos participativos e pelos conselhos setoriais, e os limites ali encontrados. Restou ainda trazer à luz justamente esse movimento de democratização e participação popular nem apesar de tampouco contra esse cenário de impossibilidade da política, mas justamente neste cenário, entre estas duas polaridades: de um lado, a aposta na disputa e na introdução de uma nova cultura política democrática e, de outro, como que expondo e cobrando os limites dessa experiência, a disputa pelos fundos públicos e sua capacidade de publicização do debate sobre o financiamento estatal e sua dimensão política.

\section{Os Orçamentos Participativos}

Dentre os mecanismos de democratização da gestão pública, o Orçamento Participativo (OP) foi considerado um dos mais fecundos e promissores espaços de disputa e compartilhamento das decisões políticas sobre a vida das cidades.

O que parece estar em questão no aparecimento do OP é a possibilidade de "invenção da política" (Oliveira, Paoli e Rizek, 2003) justamente num território urbano cujos laços entre política e cidade, tal como entendíamos na tradição sociológica, estavam desfeitos espelhando (ou, ao menos, apontando) os limites concretos das democracias liberais e da representação política. Nesse cenário de emergência de novas formas de representação e de participação nos negócios públicos, na vida da cidade e na vida política, pretendeu-se aprofundar a participação popular através de formas de democracia direta, entre elas o $\mathrm{OP}^{7}$ :

\footnotetext{
${ }^{7}$ As esperanças e apostas dos autores citados no trecho abaixo serão matizadas, e até questionadas, em outros textos escritos por eles, resultados de pesquisa desenvolvida para a Prefeitura do Município de São Paulo e apoiada pela Fundação Rosa Luxemburgo, da qual fui assistente de pesquisa, no âmbito do Cenedic, intitulada "Orçamento Participativo em São Paulo". Ver Oliveira e Rizek (2007).
} 
A invenção [o orçamento participativo] pertence à grande linhagem que vem da Comuna de Paris, passando pelas tentativas de autonomia local, desde aquelas da tradição republicano-liberal norte-americana (caricaturada nos westerns nas figuras dos xerifes e suas relações com sua comunidade) às experiências das três primeiras décadas do século $\mathrm{XX}$, aos conselhos revolucionários de Turim e da Viena Vermelha, aos conselhos populares da Hungria de 1956 (elogiados por Hannah Arendt como o antídoto à emergência de totalitarismos), às banlieues rouges da Paris até a década de 1960 e à Grenoble, Bolonha e Modena (quanto mais rica più rossa) da Itália de Bobbio e Togliatti (Oliveira, Paoli e Rizek, 2003).

Contudo, o surgimento do OP está marcado desde o nascedouro por uma dupla determinação, a qual nos permite desenhar e compreender as tensões e limites de ação e efetividade deste instrumento e é ponto de partida e objeto de análise de parte da literatura que se debruça sobre essas práticas de gestão partilhada. Por um lado, as graves restrições orçamentárias dos municípios (Bello, 2007), que impõem a essas práticas a consideração sobre o que deva ser "administrar cidades com as restrições impostas pelo modelo econômico e pelas políticas econômicas, nitidamente neoliberais, tentando responder à pergunta: como redistribuir renda nessas condições" (Oliveira, Paoli e Rizek, 2003). Importa sublinhar o fato de que há uma profunda mudança (ou quebra mesmo) do pacto federativo aberto pelos processos de municipalização das políticas públicas como parte das reformas introduzidas pelo governo Fernando Henrique Cardoso, sem a correspondente descentralização dos recursos. Um segundo aspecto, e não menos importante, é o peso da dívida pública no orçamento dos municípios.

Por outro, como transformar um instrumento de consulta e deliberação em uma prática política que realmente garanta um grau de publicização e politização capazes, inclusive, de contrapor-se àquelas determinações econômicas e aos interesses do capital que disputa, mesmo em administrações “democrática-participativas” (Dagnino, 2006), os rumos e a apropriação dos fundos públicos para além das condições (e restrições) da economia brasileira. Essa duplicidade estará presente em todas as experiências de OP nas cidades brasileiras, desde as mais conhecidas, como a de Porto Alegre e Belo Horizonte, até 
aquelas que comparecem em menor escala na literatura especializada, como na cidade de Belém ou São Pauloº.

A primeira experiência de OP data de 1989, introduzido na cidade de Porto Alegre ${ }^{9}$, então administrada pelo prefeito Olívio Dutra do Partido dos Trabalhadores, que fez a sucessão pelos quatro mandatos - doze anos - posteriores. Há referências a outras práticas de consulta à população anteriores a 1989, mas ainda sem o formato institucional do OP, como é o caso da cidade de Vila Velha, no Espírito Santo, pioneira do processo de democratização no período imediatamente anterior à promulgação da Constituição de 1988. Inicialmente proposto por administrações de frentes e partidos de esquerda, o OP foi incorporado ao programa de administrações cujos partidos não necessariamente estavam nesse campo $^{10}$. 0 descolamento desse instrumento de uma formulação política mais coerente e posicionada, ilumina o fato de que este pode ser apenas uma ferramenta de gestão e que a participação social ali concernida não é sempre (ou por si) capaz de estabelecer conflitos ou questionar as desigualdades e iniquidades das/nas cidades brasileiras.

A força inovadora e instauradora de um conflito constitutivo dos OPs está ligada à capacidade (ou possibilidade) de incidência sobre o orçamento público e sobre os fundos públicos, que, na economia moderna, são peça fundamental na acumulação do capital e, por decorrência, nas orientações e estimativas orçamentárias das políticas públicas e programas sociais governamentais. Sob este prisma, a cidade reaparece como palco de disputa e como espaço de conflito em torno dos acordos que arbitram sobre o justo e o

\footnotetext{
${ }^{8}$ Para análise da experiência de OP em São Paulo ver Rizek (2007), Bello (2007) e Sarris (2006). Leonardo Avritzer organizou a publicação A participação em São Paulo na qual estão presentes análises de várias formas de participação popular que tiveram palco em São Paulo, não só a experiência do OP (Avritzer, 2004). Ver também recente dossiê publicado no número 84 da revista Lua Nova, que se debruça sobre as experiências participativas.

9 O trabalho de Sérgio Baierle recupera em detalhes este período de formação do OP em Porto Alegre, as tradições associativas presentes no município que subsidiaram a organização popular para disputa dos rumos do governo bem como o desenvolvimento do OP na capital gaúcha nos anos iniciais de sua instalação. Ver Baierle, 2000.

10 "Em uma breve retrospectiva, pode-se ainda enfatizar que o Orçamento Participativo como instrumento de democratização e politização da gestão urbana se desenvolveu de modo bastante diverso, em algo como 140 cidades brasileiras (dado de 2000), atingindo cerca de 2\% dos municípios do país, distribuídos dentro do espectro político como se segue: das 140 cidades que dispunham em 2000 de Orçamento Participativo, 73 eram governadas pelo PT, 33 por partidos de esquerda e de centro esquerda e 34 por partidos de direita. 84\% destas cidades se localizavam no sul e sudeste; a metade das cidades cuja gestão passava pelo OP teria então menos de 100.000 habitantes e apenas $5 \%$ destas cidades contavam com mais de um milhão de habitantes" (Rizek, 2007: 135).
} 
injusto, o necessário e o possível, sobre os assuntos da vida comum dos cidadãos. Na medida em que os OPs em sua grande maioria (senão na totalidade das experiências) estão fortemente vinculados à dimensão territorial da cidade, o rebatimento desses conflitos nos espaços e territórios urbanos acabam por incidir na dinâmica interna dos conselhos gestores, fóruns e do próprio OP; assim como as disputas e novas relações que têm lugar nesses espaços políticos também informam os conflitos e as novas mediações que se entretecem no tecido urbano das cidades brasileiras.

De outra maneira, a mecânica adotada para realização das plenárias e/ou espaços de discussão e deliberação dos OPs passam quase obrigatoriamente, nas experiências que se têm registro, por uma "rodada" do bairro, do distrito ou da região, reunindo e colocando em discussão as demandas muito próximas da realidade físico-urbana da cidade. As próprias demandas apresentadas pela população nas plenárias de OPs apontam para o ressurgimento de uma dimensão físico-territorial de disputa e conflitividade importante, o que não necessariamente quer dizer democratizante ou politizada no sentido que as apostas, leituras e análises da participação popular e gestão democrática apontam.

Os dados compilados pela pesquisa desenvolvida pelo Fórum Nacional de Participação Popular sobre as experiências de OPs no Brasil dão notícias de um pequeno número de municípios que, no universo de mais de 5,5 mil, instauraram instrumentos participativos. No período de 1989 a 1992, eram 12 municípios, incluindo-se aí Porto Alegre, que se tornou referência; entre 1993 e 1996, tem-se registro de 36 experiências denominadas ou autointituladas como OPs e, por fim, este número sobe para 140 no período entre 1997 e 2000. Ribeiro e Grazia (2003) destacam a diversidade do perfil desses municípios, com uma clara concentração de experiências participativas nas regiões Sul e Sudeste:

No período 1989/1992, as mais de dez experiências de administrações locais, que iniciavam a prática nomeada de Orçamento Participativo, encontram-se concentradas nas regiões Sudeste (75\%) e Sul (25\%), envolvendo os seguintes Estados: São Paulo, Minas Gerais, Rio de Janeiro, Espírito Santo e rio Grande do Sul. Já na gestão 1993/1996, observa-se sua difusão através do registro de experiências nos outros estados da região Sul (Paraná e Santa Catarina) e no Nordeste (Bahia, Pernambuco, Rio Grande do Norte). Aumentou também o número de municípios com práticas deste tipo 
em Minas Gerais e registrou-se a primeira experiência na região Centrooeste, mais precisamente em Goiânia. Entretanto, o Orçamento Participativo surgiu, ainda na mesma gestão, como uma inovação que se difunde, com especial força, as regiões Sudeste (58,4\%) e Sul (22,3\%), para o que pesam o elevado número de municípios destas regiões, assim como a sua singular densidade político-administrativa (Ribeiro e Grazia, 2003: 28).

Ainda que tenha se espraiado para as todas as regiões do país, os orçamentos participativos seguem na gestão 1997/2000 sendo uma experiência concentrada nas regiões Sul e Sudeste, apesar da inclusão de três experiências no Norte e a difusão dos OP's no nordeste.

Tabela 5 - Distribuição do Orçamento Participativo por Região, 1997-2000

\begin{tabular}{l|ccc|}
\hline Região & $\begin{array}{c}\text { Número de } \\
\text { experiências de OP }\end{array}$ & $\begin{array}{c}\text { Percentual do total de } \\
\text { experiência de OP }\end{array}$ & $\begin{array}{c}\text { Percentual do total de } \\
\text { municípios da região }\end{array}$ \\
\hline Norte & 3 & 3.0 & 0.7 \\
Nordeste & 14 & 13.6 & 0.8 \\
Centro-oeste & - & - & - \\
Sudeste & 47 & 45.6 & 2.8 \\
Sul & 39 & 37.8 & 3.4 \\
Total & 103 & 100.0 & 1.9 \\
\hline
\end{tabular}

Fonte: Ribeiro e Grazia, 2003 (Pesquisa “Experiências de Orçamento Participativo no Brasil, 2002)

Esses dados apontados nos permitem sublinhar o caráter diverso das experiências de OP e, em certa medida, a desigualdade de condições onde eles se desenvolveram. Se por um lado é possível dizer, partindo dos dados compilados pela pesquisa citada, que os formatos institucionais de OP são bastante próximos, os contextos locais nos quais se desenvolvem não são tão homogêneos, indicando que aquilo que se chama a experiência do OP é mais uma constelação de experiências do que um conjunto monolítico reprodutível a partir de um modelo.

Há que se considerar também que as experiências tidas como paradigmáticas tanto na literatura sobre o tema quanto no campo político não são a média de seu conjunto. As cidades de Porto Alegre e do ABCD paulista que se consolidaram como modelos políticos de gestão democrática, têm características populacionais que escapam da média dos outros municípios, têm forte tradição organizativa de esquerda, apresentam índices de qualidade 
de vida acima da média nacional e seus orçamentos são superiores aqueles discutidos/deliberados pelo conjunto das experiências (o que não quer dizer que o total de recursos discutido e manejado pelo OP seja o total do orçamento municipal).

Chamo atenção para o fato de Belém, por exemplo, estar na mesma faixa de população dessas "cidades-modelo", mas com condições socioeconômicas muito diferentes - o que incide na dinâmica participativa e política da cidade. A experiência de participação popular em Belém está referida a este campo político do qual fazem parte Porto Alegre, Belo Horizonte e as cidades do ABCD paulista (como veremos a seguir), contudo é preciso ter em conta as suas diferenças em relação a estas, assim como à sua formação social e política para compreender a novidade que significou uma experiência de democratização da vida pública e de gestão da cidade.

Justamente nesse lugar em tensão forjou-se a experiência de participação popular em Belém: no primeiro momento, através a instauração de canais do OP e, passados três anos, elaborando uma forma diferente de participação política, o Congresso da Cidade. Dessa experiência nos ocuparemos a seguir.

\section{O Orçamento Participativo em Belém (1997-2000): o primeiro mecanismo de participação popular e seus desdobramentos}

Em janeiro de 1997, assumiu a administração de Belém o prefeito Edmilson Rodrigues, eleito pelo Partido dos Trabalhadores que encabeçava a chapa da Frente Belém Popular. A Frente era composta, além do PT, pelos seguintes partidos: PCdoB, PPS, PSB e PSTU $^{11}$. O autointitulado Governo do Povo assumiu pela primeira vez a gestão da cidade de Belém tendo na oposição o PSDB tanto no governo federal, que estava sob gestão de Fernando Henrique Cardoso, quanto no estadual, que tinha no comando Almir Gabriel.

\footnotetext{
11 Todos os partidos, menos o PSTU que rompeu com o governo eleito, participaram do governo durante os oito anos, à frente de secretarias, diretorias e órgãos municipais em postos de primeiro escalão. É importante dizer também que as correntes internas ao PT compuseram o governo e estavam representadas nas diversas instâncias da administração. Nos dois governos, a cadeira de vice-prefeito foi preenchida por membros de correntes diferentes da do prefeito. A única corrente petista que não participou do governo foi a liderada pelo deputado federal Babá, a Corrente Socialista dos Trabalhadores (CST), que se opunha à forma de participação popular implementada. A CST defendia a criação e o fomento dos conselhos populares como espaço de definição dos assuntos da cidade e de participação política popular.
} 
Belém, com esta administração, é a primeira capital da região Norte do país que introduz um mecanismo participativo de gestão pública, como o OP. No mesmo período, mais duas cidades da região utilizaram esse mecanismo: Xapuri, no Acre e São Miguel do Guaporé, em Rondônia.

Para compreender a experiência de participação popular durante essa gestão, é preciso antes examinar alguns pressupostos da proposta que lhe dava corpo, a animava e orientava a construção do governo. Do mesmo modo, também é preciso compreender a articulação entre os dois mecanismos de participação popular que foram postos em cena durante os oito anos desta administração.

O OP foi introduzido em 1997, no primeiro ano da gestão de Edmilson Rodrigues, e funcionou durante todo este primeiro mandato, até 2000; o Congresso da Cidade foi implantado no segundo mandato deste governo, entre os anos de 2001 e 2004. A elaboração de uma proposta de vida pública e experiência política para a cidade é, sem dúvida nenhuma, uma elaboração sobre seu passado e uma expectativa (ou uma perspectiva?) em relação ao seu futuro. Nesse sentido, as experiências do OP e do Congresso da Cidade estão ligadas porque respondem de formas diferentes, me parece, a uma questão: qual a forma de participação política e o que ela significa no conjunto da participação dos pobres e trabalhadores na gestão da cidade e mais, na vida política de sua cidade

Inicialmente esta tese tinha a intenção de estudar o Congresso da Cidade, um espaço de deliberação que o governo da cidade naquele momento reivindicava como nova e superior ao OP, pretensamente superando as dificuldades, impasses e limitações do seu antecessor. À medida que a pesquisa de campo foi avançando com a coleta de material e com as entrevistas, foi ficando claro que o OP, o Congresso da Cidade e a experiência política naquele período poderiam ser melhor compreendidos considerando-se as ligações entre os períodos em que cada um esteve em vigor e as formas de experiência política e participação popular na vida da cidade e, assim, perceber as continuidades e descontinuidades entre estes dois momentos e o que eles significaram para a história recente de Belém, e quiçá do Brasil. A passagem do OP para o Congresso por exemplo, não se fez sem tensões internas ao governo e nem mesmo em relação aos parceiros políticos deste, sejam movimentos sociais, ONGs, sindicatos ou grupamentos político-partidários. 
Curiosamente, em alguns relatos sobre o período esta passagem do OP para Congresso não é salientada nem mesmo percebida, como se o OP e Congresso de Cidade estivessem apenas em linha de continuidade. Alguns entrevistados nem mesmo distinguem esses dois instrumentos de gestão, enquanto outros marcam justamente a diferença. Em princípio, essa percepção parece ter a ver com a maior ou menor vinculação dos entrevistados à administração: quanto mais próximo do governo e, sobretudo, da sua dinâmica cotidiana, mais perceptível para os entrevistados é a transformação. Assim, os técnicos e dirigentes políticos concernidos na disputa que se deu em torno do OP marcam justamente a diferença entre os dois instrumentos, afastando as duas experiências.

Dessa perspectiva de análise, parece importante compreender que o OP e mais tarde o Congresso da Cidade estavam inseridos naquele governo como o mecanismo central de gestão democrática. Pretendia-se articular toda a administração, suas diversas secretarias e órgãos e, a partir dessa dinâmica política, realizar - ou ao menos dar passos nessa direção aquilo que, já no programa de governo da Frente Belém Popular, era designado como “avançar na constituição de um poder popular".

A participação popular se expressa na instituição de um modelo de cogestão envolvendo governo e sociedade o qual possibilita de fato a intervenção desta nos assuntos municipais. Ao formalizar a participação política da sociedade, este modelo de cogestão deve proporcionar a apropriação da cidade pela população, fazendo-a cidadã [...] Sua operacionalização demanda a constituição de espaços públicos de debate e deliberação, entre os quais o que configura o processo de orçamento participativo (Frente Belém Popular, 1996: 11).

Essa concepção, traduzida numa aposta política, estava sinalizada nos documentos que a Frente apresentou como sua plataforma política e programa de governo. Embora o OP já comparecesse no Programa de Governo da Frente, a estruturação das políticas municipais, através de programas articulados nas Marcas de Governo não estavam ainda esboçadas $^{12}$. O OP, nesse sentido, estava desenhado, me parece, muito mais como uma

\footnotetext{
12 Foram criadas sete Marcas de Governo na primeira gestão: Dar um futuro às crianças e adolescentes, Saúde para todos, Sanear Belém, Revitalizar Belém, Transporte Humano, Participação popular e Valorizar o servidor público. As Marcas de Governo designavam objetivos prioritários de atuação da Prefeitura, condensavam mais
} 
direção programática, esta inserida num conjunto de diretrizes e elaborações no campo popular e democrático, que se condensavam no chamado "modo petista de governar", do qual aquele governo de Belém era ao mesmo tempo tributário e desviante.

Trabalho com a ideia de que o autointitulado Governo do Povo de Belém pode e deve ser tratado como um dos vários governos petistas no período e, portanto, está muito informado pelo acúmulo comum das diretrizes programáticas que o PT verbalizava como a “inversão de prioridades' e "participação popular", condensados num conjunto de políticas públicas e práticas de gestão ${ }^{13}$. 0 elemento desviante está no sentido que essa formulação adquire para o conjunto de sua elaboração política; justamente aí reside a singularidade dessa aposta. Já naquele momento, o Partido dos Trabalhadores, ou mais precisamente sua direção nacional e os grupos que compunham/compõem seu campo político de sustentação, não mais apresentava, nas suas campanhas e nos seus programas de governo para as administrações locais, a construção de mecanismos gestionários articulados a uma proposta utópica, de construção do socialismo ${ }^{14}$. As características e trajetórias políticas dos agentes envolvidos diretamente com o governo de Belém, bem como pela elaboração política que daí surge e dada a constituição sociopolítica e a dinâmica própria da cidade, há elementos concretos para dizer que essa experiência de participação popular distancia-se da média das experiências petistas nos governos municipais, se analisarmos as formas de gestão instituídas e, mais ainda, as concepções e elaborações políticas que embasam essa administração.

que um programa específico e pretendiam uma ação inter-secretarial que desse organicidade e coesão às ações do governo municipal, superando a departamentalização e a segmentação da atuação estatal em secretarias e órgãos estanques. Cada Marca de Governo tinha um coordenador, que na maior parte das vezes era um secretário de governo das pastas envolvidas e agregava diversas ações públicas. Estas Marcas estavam informadas por eixos estratégicos definidos como norteadores da política municipal e eram assim designados: Desenvolvimento econômico, Inclusão Social, Identidade Cultural, Gestão Democrática e Participativa, Meio ambiente e urbanidade.

${ }^{13}$ Evidentemente esta ideia deverá ser comprovada não de uma vez só, mas ao longo desta tese, através das facetas e nuances do próprio OP e Congresso da Cidade.

${ }^{14}$ As transformações programáticas e políticas do Partido dos Trabalhadores dariam uma tese elas mesmas e já há produção substantiva sobre isto, para os fins desta tese, é importante sublinhar: a transformação política que enfocamos na leitura do PT é a da defesa do socialismo, dado que esta opção determinará, a meu juízo, o papel que os mecanismos de gestão pública e participação popular cumprem no conjunto da elaboração partidária e para as administrações petistas. Além disto, é importante resaltar que essa transformação não se fez de forma homogênea pelo país a fora, com resistências e disputas acirradas nos estados e nas cidades onde o PT foi governo. Ademais é importante sinalizar que a administração de Edmilson Rodrigues será contemporânea dos dois primeiros anos do governo Lula e esta coexistência não foi pacífica. 
Durante o processo eleitoral, a essa concepção de construção de uma nova sociedade somou-se a necessidade de responder à expectativa de transformação e mudança que se constituíram como principal elemento de aglutinação dos setores organizados - e, posteriormente, da população em geral - que aderiram à campanha e elegeu o prefeito. Expectativa figurada na ideia de que "a cidade avermelhou"15, imagem que os interlocutores desta pesquisa utilizaram, numa alusão à força da campanha e à afirmação dos símbolos e da mística petista, naquele momento, muito intensa em Belém.

A montagem do OP em Belém foi uma das primeiras ações de governo e respondia, segundo as entrevistas realizadas, à necessidade de manter a mobilização popular que levou à eleição da Frente, bem como iniciar o processo de gestão democrática na cidade.

O Edmilson se elege com base num impulso popular muito forte. Então, a expectativa não podia ser fraudada. Digo isso com muita clareza, por que as pessoas imaginavam que o Edmilson vinha pra mudar mesmo o status quo da política e havia, portanto, uma expectativa exagerada atrás daquela nossa capacidade de responder. Então, nesse sentido, o fato do nosso governo já nos primeiros dias, já no seu nascedouro, ter buscado expressar um conteúdo voltado à radicalização da participação social, do controle social, da participação social, isso não terá respondido apenas a um desejo nosso programático, era uma exigência mesmo. Quer dizer, não havia outra forma de você poder dialogar com aquela expectativa que tinha, ao fim e ao cabo, levado à vitória. Então é um governo marcado, já desde o seu iniciozinho, pela realização de chamamento e de conclamações à participação popular, assembleias, reuniões muito amplas. Eu acho que não demorou nem três meses pra que o Orçamento Participativo tivesse sido organizado, foi o tempo suficiente apenas de se chegar à montagem de uma primeira estrutura, de uma equipe (Aldenor Júnior ${ }^{16}$, entrevista concedida à pesquisadora, 2 de dezembro de 2009).

\footnotetext{
15 A expressão vem de uma música muito popular à época cantada por Fafá de Belém, chamada Vermelho, símbolo de um dos mais famosos clubes de Boi de Parintins (AM), o Garantido, e que foi utilizada na campanha de Edmilson Rodrigues. Vejamos parte da letra: "A cor do meu batuque / Tem o toque, tem o som / Da minha voz / Vermelho, vermelhaço / Vermelhusco, vermelhante / Vermelhão... / O velho comunista se aliançou / Ao rubro do rubor do meu amor / O brilho do meu canto tem o tom / E a expressão da minha cor / Meu coração!... / Meu coração é vermelho [...]"

${ }^{16}$ Aldenor Araújo Júnior foi Chefe de Gabinete e Coordenador de Comunicação Social (Comus) do governo Edmilson Rodrigues durante os oito anos da administração.
} 
Os encarregados diretamente pelo prefeito dessa montagem do OP foram Esther Bemerguy, então secretária de Planejamento e posteriormente Secretária de Finanças, e Stefani Henrique ${ }^{17}$, que esteve à frente da Coordenadoria de Relações com a Comunidade (CRC), durante toda a primeira gestão. A montagem do OP aconteceu, de fato, em três meses, entretanto, seu formato institucional transformou-se ao longo dos quatro anos seguintes. As experiências de Belo Horizonte e Porto Alegre estavam no horizonte do novo governo, como relata Edmilson Rodrigues, e serviram de espelho e base, mas também de anteparo crítico para a realização do OP em Belém.

A experiência de Porto Alegre e do [prefeito de Belo Horizonte] Patrus Annanias foram, pra nós, referenciais. Então, levamos companheiros que participavam da experiência em Belém, visitamos as cidades para ver como estavam sendo feitas e compusemos, então, uma estrutura de participação para apresentar à sociedade. Nós tínhamos que ter iniciativa. [...] Criamos a CRC, foi o Stefani que coordenou, fez viagens para conhecer experiências. E começamos a convocar o cidadão para debater, através de plenárias. A participação no início foi muito pequena, em todo caso esta participação foi legitimando aquela construção (Edmilson Rodrigues, entrevista concedida à pesquisadora, agosto de 2005).

Dessas visitas a outras experiências, surge um formato institucional do OP em Belém que manteve uma estrutura básica de funcionamento bastante próximo ao de Porto Alegre e Belo Horizonte, mas introduziu alguns elementos institucionais de funcionamento e controle social.

\section{Estrutura e funcionamento do OP, algumas questões}

A participação popular parece ter sido o diapasão escolhido pelo governo municipal para afinar e medir a realização de suas políticas setoriais, bem como a forma de condução dos negócios públicos. E foi com esse tom que a administração eleita propôs uma estrutura

\footnotetext{
17 Depois, no segundo mandato, Stefani Henrique coordenou os trabalhos do Congresso da Juventude.
} 
visando à democratização do Estado, que combinava elementos de democracia representativa e de democracia direta.

O OP em Belém tinha uma estrutura que combinava elementos de democracia direta e de democracia representativa e entrecruzava as formas de acesso a espaços de funcionamento e deliberação à base territorial. A elaboração do orçamento durava um ano, que se iniciava no mês de março com a discussão e a organização das demandas que embasavam a montagem de uma peça orçamentária feita pelo Executivo (sua obrigação legal) que, remetida à Câmara, era votada e guiava a execução orçamentária do ano seguinte.

Além do OP, foram implantados na cidade conselhos, fóruns e espaços de debate que viabilizavam a discussão das políticas públicas setoriais. Sobre os conselhos, é preciso dizer que parte deles foi definida por legislação federal, no bojo do processo de democratização nos anos 1990 depois da promulgação da Constituição de 1988, como é o caso dos conselhos municipais de saúde, de educação, de assistência social, do conselho tutelar de proteção à criança e ao adolescente. A ação municipal foi no sentido de fomentar a atividade destes e inseri-los como novos mecanismos de representação popular em âmbito municipal ou como interlocutores privilegiados na elaboração de suas políticas setoriais. Alguns conselhos municipais foram estabelecidos anteriormente à administração petista, como o conselho de desenvolvimento urbano e meio ambiente, estabelecido pelo Plano Diretor, e os conselhos municipais da condição feminina, de alimentação escolar, entre outros. Alguns novos conselhos municipais foram criados pela gestão Edmilson Rodrigues como parte da sua política de ampliação da participação popular na administração pública, foram eles: o conselho municipal do negro, de entorpecentes, de transportes, de desenvolvimento econômico e social e de proteção ao patrimônio cultural, turismo e cultura.

A discussão do orçamento municipal, coordenado pela CRC, era deflagrado através de atividades de mobilização da população nos bairros, de convocação para plenárias e de formação que antecediam à discussão sobre o orçamento propriamente. Essas atividades eram organizadas, fomentadas e viabilizadas por uma equipe de assessores que trabalhavam diretamente na coordenação do OP, ligados à direção da CRC, e outra equipe de campo formada por oito agentes mobilizadores (um para cada distrito administrativo) com atuação direta nos bairros. 
Belém teve sua configuração administrativa e territorial modificada - ainda que pontualmente - através da criação de novos distritos, que funcionaram como Administrações Regionais para alguns assuntos, mas sem descentralização efetiva na gestão dos recursos. Belém foi, desde 1997, dividida em oito distritos administrativos (DA): Mosqueiro (DAMOS), Outeiro (DAOUT), Icoaraci (DAICO), Benguí (DABEN), Entroncamento (DAENT), Sacramenta (DASAC), Belém (DABEL) e Guamá (DAGUA). Importa sublinhar que a reorganização administrativa dos distritos estava no bojo da construção de mecanismos de gestão democrática da cidade que em Belém recebeu o nome de Planejamento Estratégico Participativo ${ }^{18}$ e teve como propósito aproximar a população dos mecanismos e instrumentos administrativos de gestão urbana, possibilitando um maior diálogo entre os moradores do distrito e os representantes da administração municipal, todos indicados pelo prefeito. É possível dizer que ocorreu uma descentralização administrativa, que outorgou autonomia política relativa aos Distritos Administrativos.

Entretanto, essa nova divisão territorial acabou por incidir na organização dos movimentos de bairros da cidade, operando - ainda que sem querer - uma redefinição de redes e vínculos entre estes movimentos, associações e organizações de bairro.

Então é uma dinâmica [de divisão administrativa] que o OP instala no município que nós nunca tínhamos registrado. Isso por exemplo é um elemento da nossa critica naquela época [ao governo]. [...] Não só a forma como o governo fez isso, mas também os próprios movimentos sociais começaram a se estruturar a partir dessa dinâmica do governo. Esse foi um dos problemas dele e, do meu modo particular de ver, porque não eram as dinâmicas dos movimentos sociais, as organizações não se estruturavam por distrito. Mas acabou que essa estrutura organizativa da prefeitura acabou balizando a estrutura também das organizações. [...] É

\footnotetext{
18 Planejamento estratégico é um termo cunhado por Manuel Castels e Jorge Borja para designar uma forma de ação sobre o espaço urbano, situada no campo da estratégia mercadológica, que trabalha com o pressuposto de que as cidades são palcos de negócios e que esta lógica de intervenção através de forças privadas é um mecanismo central nos processos de "revitalização" urbana. A crítica a essa vertente das intervenções urbanas recentes tem em Otília Arantes e Carlos Vainer como referências importantes. A Prefeitura de Belém naquele período elaborou um Planejamento Estratégico Participativo, na contramão daquela corrente, pois, a meu juízo, disputou politicamente sentidos da ação no espaço urbano. Para o debate em torno do planejamento estratégico e suas intervenções paradigmáticas, ver especialmente Arantes, Vainer e Maricato (2000). Para uma discussão sobre o Planejamento Estratégico Participativo em Belém, ver Maria Lúcia Refinetti Martins (s.d.).
} 
completamente errado...? Talvez não seja, mas é um problema se você não está preparado para aquela dinâmica. [...] Pra mim essa foi uma das dificuldades iniciais pro próprio movimento e que vai repercutir durante todo governo: essa reação e adaptação de um conjunto de movimentos sociais a uma dinâmica oriunda do aparelho do estado. Isso é muito complexo porque mexe com tradições de luta ou de organização, isso cria dinâmicas que não são dinâmicas vivenciadas pelo governo (Guilherme Carvalho, entrevista concedida à pesquisadora, 4 de dezembro de 2009).

O OP começava com rodadas de plenárias territoriais nos bairros para discussão das demandas da população e levantamento de propostas, chamadas assembleias de microrregião. Eram realizadas assembleias de microrregião distribuídas nos oito distritos administrativos. Nessa etapa era discutida a prestação de contas do governo do plano de investimento do ano anterior; coletava-se e discutiam-se as demandas dos bairros que chegavam através dos moradores que participavam da atividade e elegiam-se os delegados para a próxima etapa, a assembleia popular distrital. 0 número de delegados eleitos era função da participação das pessoas de comunidades organizadas na plenária, na proporção de dez pessoas para um delegado. A participação individual nessas assembleias regia-se pela proporção de 20 presentes para 1 delegado e indicava-se os suplentes na proporção de $30 \%$ dos delegados efetivos.

Em 1997, primeiro ano do OP, foram distribuídas "fichas de demandas" para que a população expressasse suas reivindicações, o que resultou numa quantidade imensa de exigências fragmentadas que totalizaram algo em torno de 60 mil demandas de obras e serviços, o que quase inviabilizou a sistematização para apresentação à população, segundo reporta Stefani, dado o alto grau de pulverização e especificidade das solicitações de serviços e benfeitorias que acorreram para as plenárias territoriais. Já no segundo ano do OP, 1998, a metodologia utilizada para colher essas demandas foi modificada: na inscrição para a plenária cada morador participante dizia suas reivindicações que eram anotadas e sistematizadas pelos funcionários da Prefeitura que coordenavam a plenária, procedimento que, por si só, funcionava como um filtro das solicitações e demandas populares. 
Introduzida já no segundo ano de governo, em 1998, essa rodada territorial traz uma novidade em relação à média dos OPs em outras cidades brasileiras $^{19}$ : elegiam-se delegados com base no voto direto, sendo esse colégio eleitoral formado pelos moradores que participassem das atividades preparatórias, as plenárias territoriais. No ano de 1997, quando da introdução do OP, a delegação ainda foi indireta, através de voto de delegados na assembleia de microrregião. Os números de participação nas eleições diretas para os delegados do Conselho do Orçamento Participativo (COP), sistematizados pela CRC, dão conta de um colégio eleitoral que variou entre 20 mil a 30 mil pessoas e da eleição direta em urna, cujo comparecimento não era obrigatório, entre 4 mil a 5 mil pessoas anualmente. 0 número de delegados a ser eleito em cada distrito era função de sua população.

$\mathrm{Na}$ etapa seguinte do OP, realizavam-se as oito assembleias populares distritais, composta pelos delegados eleitos anteriormente. A este plenário era delegada a função de discutir e definir as prioridades do distrito; analisar o cronograma de obras do OP e eleger 30 delegados e seus suplentes para a Assembleia Popular Municipal.

Faziam parte da estrutura do OP as plenárias temáticas destinadas a discutir questões gerais que concerniam à cidade como um todo, dentro do âmbito de um tema ou setor. Discutiam-se obras, demandas estruturais e plurianuais da cidade e também se elegiam delegados ao COP, que, juntamente com os outros delegados eleitos nas assembleias populares, formavam um conjunto de aproximadamente 100 membros do COP.

Olinda Malato (2006) destaca que as plenárias temáticas atraiam setores mais organizados para o debate de políticas públicas setoriais, enquanto as plenárias territoriais, por ser um espaço delimitado geograficamente, tendiam a receber demandas mais focalizadas e referidas à dinâmica local de cada bairro, conglomerando um conjunto de pessoas menos ou nada organizadas. Se, grosso modo, é possível concordar com essa avaliação, também é preciso fazer uma ressalva: a grande participação e peso que o movimento de moradia teve no OP, através das já citadas CBB e da Femecam, movimentos de forte base territorial.

\footnotetext{
19 Segundo dados da Pesquisa "Experiências de Orçamentos Participativos no Brasil", compilados por Ribeiro e Grazia (2003), a escolha dos delegados do OP era feita da seguinte forma: 65\% das cidades indicavam delegados eleitos em assembleia; $18 \%$ das experiências não tiravam delegados; em 6\% dos casos os delegados eram eleitos em chapas, por voto secreto em assembleia; e apenas 4\% das cidades elegiam seus delegados ao OP por voto secreto, o que corresponde a quatro experiências do universo pesquisado.
} 
Não é menos importante o fato de que a administração contou com esses movimentos sociais (e outros com mesmo perfil organizativo e político) como sua base política e social na campanha eleitoral e, durante a administração, como um dos seus principais interlocutores. Esses segmentos de movimentos sindicais, sociais e populares estão na base da formação do PT no Pará e a relação com o partido, sua vida interna e seus grupos políticos, assim como na luta social, remonta a períodos anteriores a essa administração. Vale sublinhar que esse alinhamento político não desabona a gestão ou mesmo os movimentos em questão, mas coloca luz sobre uma relação tensa que se estabelece entre sociedade e Estado, em administrações com corte político programático à esquerda.

Se, por um lado, a Frente Belém Popular, seus principais formuladores e o próprio prefeito refutam uma visão política basista, pra usar a terminologia política-partidária, ou, de outra forma, uma formulação contraposta à tradição autonomista e conselhista, essa articulação entre Estado e movimentos sociais não se fez sem tensões.

Aí vem um debate importante porque, às vezes, tem uma visão meio espontaneísta, de base autonomista, talvez de certa influência, certo matiz das comunidades eclesiais de base, mas que advogam uma ideia de que o governo não pode tomar iniciativa porque seria desrespeitar, passar por cima [dos movimentos e da sociedade civil] (Edmilson Rodrigues, entrevista concedida à pesquisadora, agosto de 2005).

Nesta fala, Edmilson Rodrigues afirma o papel indutor do Estado nos processos de organização política e disputa a legitimidade de uma ação política claramente orientada, tomando o governo como um momento importante, se não necessário, de democratização do aparelho estatal. Revela a constituição de uma proposta política que percebe na administração municipal um espaço importante de acúmulo de forças para transformação social, que deve garantir ganhos substantivos na vida do povo através da estruturação de políticas públicas universais e avanços políticos e organizativos dos setores populares na direção de uma transformação mais profunda da sociedade. 0 governo aqui não é visto apenas como um "realizador do bem comum", mas como um agente político que assume um lado no conflito, no âmbito de uma sociedade clivada por classes. 
Essa formulação que, já na plataforma eleitoral, reafirmou seu compromisso com a construção do socialismo, advogava o papel indutor das mudanças nessas estruturas de Estado orientado pela premissa da democratização deste. É uma aposta informada pela ideia de que mesmo pequenas mudanças no aparelho estatal, pequenas reformas - através da afirmação do caráter universal de políticas públicas, na contraposição às carências históricas vividas pelo "povo" - frente ao caráter patrimonialista do Estado brasileiro e a importância deste como fiador do desenvolvimento do capitalismo no país, poderiam tornar-se grandes fissuras, uma vez que o capitalismo e as elites dirigentes não toleram nenhum grau de regulação e baniram qualquer sentido de igualdade ${ }^{20}$ da vida política no país.

Essa tensão está presente também na mecânica do $\mathrm{OP}$, ou seja, no próprio funcionamento das plenárias que articulam nas plenárias e atividades setoriais a participação de amplos coletivos de pessoas sem que sua organização prévia conte e a participação de setores organizados. E, em certa medida, essa tensão aguçou-se a tal ponto que causa celeuma no próprio governo, informando inclusive as avaliações sobre a eficácia do instrumento como elemento democratizante de gestão pública.

Esse foi um grande debate. [...] Nós priorizávamos a democracia direta. Então é o seguinte, a Joana pode ser conselheira da OP, desde que ela seja eleita no fórum correto, através da eleição direta. Então ela pode ser delegada do OP, desde que ela dispute lá na comunidade e ganhe a eleição do delegado. Joana é presidente do centro comunitário, isso não a torna delegada nata. Entendeu? Então, essa foi a polêmica porque alguns companheiros defendiam, até mesmo o próprio PT, que nós estávamos esvaziando as entidades, o que não é verdade. Nós estávamos optando pela democracia direta, tá. Se a gente dá um privilegio a uma pessoa que é presidente de centro comunitário, muitas vezes nós iríamos estar mantendo uma estrutura velha que já estava aí. Agora o cara que tem base, ele só precisava reunir dez, era ele e mais nove, entendeu? Ele reunia um e mais nove, ele estava eleito. Agora, "ah eu sou presidente do centro eu quero ser eleito", não, não pode. Mas no COP nós tínhamos o espaço das entidades, tá.

20 Trabalho com o sentido de igualdade contingente, nos termos de Jacques Rancière, conceito desenvolvido no capítulo 1 desta tese. 
[...] Também foi [uma polêmica] no governo, mas prevalecia para nós concepção de democracia direta, que é a mesma de Porto Alegre, era a mesma coisa em Porto Alegre, democracia direta, entendeu? (Stefani Henrique, entrevista concedida à pesquisadora, 04 de agosto de 2008).

0 peso que os movimentos sociais de massa, especialmente os de moradia, têm sob os OP's e outros mecanismos de participação popular na gestão municipal não é só uma questão para a cidade de Belém, mas podemos vê-la aparecer em outros lugares como São Paulo e Belo Horizonte ${ }^{21}$. Em certa medida, é possível dizer que essa polaridade explicita a tensão entre necessidade e política, para usarmos os termos de Hanna Arendt. A participação de amplos setores populares é facilitada por uma dinâmica política dispersa territorialmente, como nas plenárias de bairros, com grande capacidade de diálogo com as demandas imediatas e pertinentes ao cotidiano da vida desses setores.

Entretanto, é preciso ponderar até que ponto esta participação numérica ultrapassa a gestão das precariedades ou, de outro modo, supera os seus limites e abre a possibilidade efetiva de uma participação política que se constitua naquilo que Rancière chama de subjetivação política. Não se trata de medir a capacidade política ou a eficácia deste ou qualquer outro instrumento de participação popular.

Essa crise do financiamento do ente político município, eu acho que esse é um elemento fundamental que limita e tenciona a resistência de um processo de participação popular, porque você vai levantar um conjunto de demandas que geralmente correspondem a uma divida social acumulada em décadas, em longos períodos. E você tem quatro anos ou oitos anos no caso de reeleição pra tentar resolver. [...] Então é essa necessidade de mediar o atendimento das demandas concretas, portanto um investimento

\footnotetext{
${ }^{21}$ Exemplo paradigmático dessa relação de mútua determinação parece ser, em Belo Horizonte, a constituição do Orçamento Participativo de Habitação (OPH) em decorrência da presença massiva dos movimentos de habitação nas instâncias do OP da cidade. As tensões e conflitos que aconteciam na disputa pelos recursos do orçamento, dada a capacidade das associações e, portanto, a capacidade de "definirem" a destinação de um grande volume de recursos para suas demandas, fez surgir a proposta de discussão em separado das demandas habitacionais através de um mecanismo com as características do OP, que, desde 1996, está em vigor. E sob críticas também. Esse processo foi analisado na pesquisa coordenada pela professora Cibele Rizek, intitulada "Procedimentos inovadores de gestão habitacional para população de baixa renda", entre maio 2001 a dezembro 2004, e está no relatório escrito por Marta Bergamin e por mim, não publicado. Para análise desse processo, ver também Ribeiro (2001).
} 
e uma priorização de recursos pra essas demandas sociais, ao mesmo tempo em que você não limita é a isso, teria que fazer um processo de formação continuada, de formação política, de politização social (Aldenor Araújo Jr, entrevista concedida à pesquisadora, 02 de dezembro de 2012).

O que parece estar em questão é a possibilidade dessa participação política fomentada e potencializada pelo OP e por outros espaços deliberativos instituídos, ultrapassar a gestão das precariedades, transbordar os seus limites orçamentários restritos e permitir à população, que ali se apresenta, encenar sua condição e, a partir dessa encenação ou desta subjetivação política, inquirir o conjunto da sociedade à reparação das desigualdades sociais, ou, ainda nos termos de Rancière, à reparação do dano.

No primeiro ano do OP, apenas dois temas foram debatidos nessa rodada: Saúde/Saneamento e Educação. A partir de 1998, outros temas foram incorporados à agenda e as plenárias passaram a discutir os eixos temáticos, aglutinados em torno das Marcas de Governo ${ }^{22}$. As plenárias temáticas do OP foram assim definidas: Dar um futuro às crianças, Revitalização de Belém, Sanear Belém, Saúde para todos, Transporte humano, e Administração e tributos.

Outra instância do Orçamento era o Orçamento Popular da Juventude (OP-J) que tinha um funcionamento parecido com o OP "geral", apenas com menor número de etapas e instâncias; eram ao todo três rodadas de discussão que congregavam jovens de 12 a 25 anos e discutia os temas de cultura, esporte e lazer. Dessa discussão, montava-se um plano de investimento para o setor dentro dos valores estipulados pelo COP. A coordenação do OP-J elegia uma comissão de cinco pessoas que tinham assento, mas não voto, nas reuniões do COP, além de na terceira rodada elegerem-se vinte observadores para a Assembleia Popular Municipal.

O OP-J foi uma inovação em relação ao formato original que serviu de base para a formatação do OP em Belém, tendo sido alvo de críticas internas à administração bem como

\footnotetext{
22 As chamadas Marcas de Governo orientaram a administração e ação combinada entre secretarias como uma forma de quebrar a gestão estanque e fracionada dos problemas. As Marcas de Governo - que perduraram durante as duas gestões com mudanças e ampliações - foram espécie de polo aglutinador de políticas públicas setoriais que convergiam para um determinado foco, através da ação combinada de diversos órgãos e setores das secretarias municipais.
} 
do público em geral, especialmente os setores mais conservadores da cidade, críticas estas que nasciam em função dos desdobramentos organizativos que o OP-J significou, com forte mobilização e organização da juventude e incidência na política local. Internamente à administração e ao COP, a polarização sobre a pertinência ou não do OP-J tinha como centro a possibilidade de fragmentação do instrumento político, criando nichos e segmentações na participação popular e na discussão do orçamento. A CRC, entretanto, na figura do seu coordenador, acreditava na necessidade de espraiar a participação para a juventude, uma vez que a dinâmica dos espaços "normais" do OP não proporcionava uma efetiva participação dos jovens. Interessante notar que essa observação de Stefani pode ser tomada como exemplo das dificuldades de acesso e afetiva participação nesses espaços para alguns setores que têm demandas próprias ou cuja participação é muito comprometida dos espaços políticos correntes, como é o caso das mulheres (as experiências de outras cidades reportam esta dificuldade), ou, no caso de Belém, os indígenas ou homossexuais ${ }^{23}$.

$\mathrm{Eu}$ argumentava o seguinte: que existia uma grande parcela de jovens que participavam nas assembleias, mas eles só iam até a segunda fase, eles não iam até o final. O OP ele ia ficando envelhecido, conforme ele fosse [andando], ele ia ficando envelhecido, masculino [...] conforme ele fosse chegando ao final, entendeu? Então, nós identificamos que precisava ter um processo que envolvesse o jovem até o final, pela quantidade de jovem que tem, pela vontade política que eles tinham de participar. Então, ao invés de segmentar a gente delegou mais. Nós criamos a OP-J, que elegia as demandas da juventude, porque ela não tinha a demanda dela atendida, se está lá no final uma rua, uma escola e uma quadra de skate, a quadra de skate não passa nunca, nunca. Então precisava criar um processo que [o jovem] demandava as demandas da juventude. E foi muito legal, foi muito bom porque nós criamos arenas, criamos incentivo a grupos culturais, espaço esportivo, espaço de cultura... foi muito bom. [Então o OP-J na verdade funcionava quase como outro setor?] Era paralelo, que se juntavam no final, tá. [...] E esses dez milhões, a quantidade de recurso que ia para a

\footnotetext{
${ }^{23}$ Parte destas dificuldades será objeto de discussão na cidade de Belém e é um dos motivos levantados pela administração para conversão do OP em Congresso da Cidade. Esta transformação será tratada à frente.
} 
OP-J, a juventude tinha que vir disputar aqui no COP, no geral (Stefani Henrique, entrevista concedida à pesquisadora, 04 de agosto de 2009).

Ao final da etapa de assembleias distritais, plenárias temáticas e do OP-J, o COP estava montado, através da eleição de delegados que, a partir daquele momento, assumiam uma sorte de tarefas de acompanhamento de discussão e montagem do orçamento municipal e de cogestão da política tributária e financeira da prefeitura.

Resumidamente, o COP era composto da seguinte maneira: três conselheiros eleitos através de votação secreta em urna, em cada uma das oito regiões administrativas; dois conselheiros eleitos em cada uma das Planárias Temáticas; um representante do sindicato dos funcionários públicos; um representante das entidades de movimento popular (CBB e Femecam) e dois representantes do Executivo, estes sem direito a voto.

$\mathrm{Na}$ Assembleia Municipal do OP, composta pelos delegados das assembleias distritais e das plenárias temáticas, mais os conselheiros do COP, debatia-se a política de desenvolvimento para a cidade e aprovava-se um esboço de orçamento com o escalonamento das prioridades. Essa peça era remetida ao COP para sua aprovação.

Antes dos membros do COP discutirem e montarem essa proposta de peça orçamentária a ser enviada à Câmara de Vereadores, com as prioridades debatidas e aprovadas na Assembleia Municipal do OP, havia uma etapa em que os conselheiros e delegados visitavam conjuntamente os locais que tinham sido apontados pelas etapas anteriores como demandas. A "Caravana de Prioridades", depois chamada "Caravana da Cidade", foi uma atividade proposta para que os conselheiros tivessem a possibilidade de conhecer a realidade da cidade como um todo e, assim, pudessem ter elementos de julgamento das demandas que chegavam ao COP, para além da lógica de repartição dos poucos recursos entre todos ${ }^{24}$. A caravana era custeada pela prefeitura e envolvia também as secretarias municipais. Além de visitarem e conhecerem os locais que estavam na lista de prioridades, os delegados e conselheiros conversavam com as lideranças locais. Esse mecanismo gerou, segundo o relato de Stefani Henrique, uma dinâmica curiosa dentro do OP: a negociação entre os bairros ou entre as entidades de moradores de bairros.

\footnotetext{
${ }^{24}$ Este recurso foi utilizado em outras administrações que instalaram OPs. 0 objetivo desta Caravana era a mesma: as lideranças locais tivessem a visão mais totalizante e menos fragmentada dos problemas da cidade.
} 
Pesquisa da prefeitura, desenvolvida pela Gestão Venturi Consultoria com os participantes do Fórum Municipal, mostra que daqueles que participaram das Caravanas de Prioridades do OP, em 1998, a imensa maioria relata que o conhecimento sobre a cidade aumentou, assim como sua posição sobre as prioridades do OP também foram mudadas em função desta atividade ${ }^{25}$.

Os valores discutidos pelo OP cresceram gradativamente ao longo dos quatro primeiros anos de governo. No primeiro ano, a população discutiu $70 \%$ dos valores estimados do IPTU para 1998 (ano seguinte) ou o equivalente a 54\% do total de investimento da PMB, cerca de 15 milhões de reais à época, e em 1999, este percentual chegava a 100\% da estimativa de arrecadação ${ }^{26}$. Em 2000, além de discutir o total de investimentos da prefeitura de Belém, os delegados e conselheiros deliberaram sobre as verbas de custeio e de pessoal. Esse percentual é muito acima dos valores praticados por outras administrações que implantaram o OP, conforme podemos ver pela leitura das tabelas 3 e 4 abaixo.

Tabela 6 - Proporção do orçamento global deliberada no OP (1997-2000)

\begin{tabular}{l|cc|}
\hline Proporção & № de citações & Incidência \% \\
\hline De 1 a $5 \%$ & 18 & 17 \\
De 6 a $10 \%$ & 18 & 17 \\
De 11 a $15 \%$ & 7 & 7 \\
De 16 a $20 \%$ & 3 & 3 \\
De 21 a $25 \%$ & - & - \\
De 26 a $30 \%$ & - & - \\
De 31 a $35 \%$ & - & - \\
De 36 a 40 & 3 & 3 \\
Mais de $40 \%$ & 6 & 6 \\
Não delibera sobre recursos & 10 & 10 \\
Não respondeu & 38 & 37 \\
Total & 103 & 100 \\
\hline
\end{tabular}

Fonte: Pesquisa “Experiências de Orçamento Participativo no Brasil, 2002" (Ribeiro e Grazia, 2003: 86).

25 A tabela "Conhecimento sobre os problemas da cidade, pós Caravana" indica que para o universo pesquisado: $2 \%$ relatam que "não mudou/não viu nada de novo", $23 \%$ que "aumentou um pouco" o conhecimento sobre a cidade e $75 \%$ dizem que seu conhecimento sobre a cidade "aumentou muito". A pesquisa ainda revela, na tabela "Posição a respeito das prioridades discutidas no FM, pós Caravana" que para $13 \%$ dos entrevistados "continuou a mesma. Continuei defendendo as mesmas prioridades de antes da Caravana", para 38\% "Mudou um pouco. Além das prioridades que já defendia passei a defender outras" e para $49 \%$ dos entrevistados "Mudou muito. Ao conhecer os problemas da cidade como um todo passei a defender outras reivindicações que agora considero mais importantes". Fonte: CRC-PMB/Gestão Venturi, "Orçamento Participativo - Estudo junto aos representantes da população no Fórum Municipal: Perfil e avaliação", setembro de 1998.

${ }^{26}$ Estes valores são provenientes das publicações da PMB à época da gestão Edmilson Rodrigues. 
Tabela 7 - Proporção dos Investimentos deliberada no OP (1997-2000)

\begin{tabular}{l|cc|}
\hline Proporção & № de citações & Incidência \% \\
\hline De 1 a 10\% & 15 & 15 \\
De 11 a 20\% & 5 & 5 \\
De 21 a 30\% & 4 & 4 \\
De 31 a 40\% & 5 & 5 \\
De 41 a 50\% & 7 & 7 \\
De 51 a 60\% & - & - \\
De 61 a 70\% & 2 & 2 \\
De 71 a 80\% & 5 & 5 \\
De 81 a 90\% & 1 & 1 \\
De 91 a 99\% & - & - \\
100\% & 22 & 21 \\
Não delibera sobre recursos & 10 & 10 \\
Não respondeu & 27 & 26 \\
Total & 103 & 100 \\
\hline
\end{tabular}

Fonte: Pesquisa "Experiências de Orçamento Participativo no Brasil, 2002" (Ribeiro e Grazia, 2003: 88).

A efetividade de processos participativos tem sido duramente criticada justamente porque a soma de recursos debatidos e deliberados pela população das cidades que instalaram orçamentos participativos é bastante reduzida, em torno de $10 \%$ dos recursos totais. Entretanto, ao se considerar os dados - mesmo que imprecisos - da pesquisa, é possível perceber que os valores de investimentos em $22 \%$ dos municípios sua população delibera sobre o total dos investimentos municipais, enquanto que em outras $15 \%$ incidem sobre até $10 \%$ destes.

Tanto o OP como o Congresso da Cidade nunca foram instituídos por lei municipal, assim como a instância que coordenava o processo participativo na cidade ${ }^{27}$. A CRC nunca foi instaurada por lei, "mas sempre teve porte de secretaria", como frisa Edmilson Rodrigues, ligada ao Gabinete do Prefeito e sediada na Secretaria de Planejamento. A justificativa institucional para essa opção, difundida nos textos que a prefeitura editou sobre as duas gestões, assim como na fala de seus principais quadros, dá notas de uma opção política por um arranjo institucional que permitisse que a experiência de participação popular na gestão da cidade fizesse e refizesse os acordos entre aqueles que participavam dos espaços e fóruns de forma menos enrijecida possível, e que os participantes pudessem a cada ano pensar e construir as normas e acordos coletivos que

\footnotetext{
${ }^{27}$ Ribeiro e Grazia (2003) indicam que no período de 1997 a 2000, das 103 experiências de OPs brasileiros, apenas em nove municípios não foram instituídos por legislação específica, mas por outros instrumentos jurídicos que garantiam sua existência e funcionamento.
} 
balizavam essa ação política. Dessa perspectiva, o OP e mais fortemente o Congresso da Cidade (como se verá adiante) poderiam constituir-se como mecanismos de experiência política de autonomia e de constituição de um "poder popular" em contraposição às formas instituídas e institucionalizadas da vida política.

Essa justificação está em consonância com a centralidade que o mecanismo de instituição e coordenação do OP teve ao longo da primeira gestão municipal e a importância e peso político que tiveram durante os oito anos desta. A ligação da CRC diretamente ao Gabinete do Prefeito demonstra a importância e a centralidade que a participação popular pensada como política de governo - teve ao longo daqueles oito anos. Além disto, a CRC funcionou muitas vezes como uma espécie de núcleo político e articulador da gestão, o que causou alguns problemas com os partidos aliados do governo bem como a base popular da administração.

O OP em Belém teve centralidade política e podemos dizer que efetivamente tornouse o locus de discussão sobre a gestão da cidade no período. A essa percepção, corroborada pelos depoimentos dos entrevistados, ainda que haja percepções diferentes do grau de efetividade e aprofundamento desta experiência por parte desses interlocutores, se soma outra constatação importante: mesmo sendo o OP a "marca" da participação, existiam outras formas e espaços de participação popular que se entrecruzaram durante a gestão do "governo do povo". Os instrumentos de gestão participativa deveriam organizar e redefinir a dinâmica interna da máquina administrativa - refletindo assim as mudanças de cultura política tão ansiadas - e, por outro lado, permitir e facilitar que em cada secretaria e/ou espaço de gestão municipal o "povo belenense" fosse ouvido e participasse das definições de governo.

Cada área definiu, digamos assim, uma estratégia para aglutinar o processo participativo. Então, mesmo tendo OP que era a instância maior da participação, da mobilização, da discussão sobre a cidade, sobre os problemas, sobre o orçamento e tal, mas todas as áreas tinham que agregar na sua política o processo participativo. Se definiu, se não me engano, cinco $^{28}$ diretrizes que foram definidas... [...] E esses eixos eram eixos aglutinadores não só da viabilização da política da rotina, do cotidiano, do

\footnotetext{
${ }^{28}$ Na verdade foram sete "Marcas de Governo" e cinco "Eixos Estratégicos", conforme nota acima.
} 
planejamento da gestão e tal, mas também o eixo que aglutinava o processo de participação (Sandra Helena $\mathrm{Cruz}^{29}$, entrevista concedida à pesquisadora, 4 de dezembro de 2009).

A concepção de participação popular como um leque de possibilidades de interferência e experiência políticas múltiplas - ainda que muito tensionada pelo "safado da vida", como diria Riobaldo em Grande Sertão: Veredas, ou seja, pelas necessidades urgentes e pelo imperativo da divisão de parcos recursos por muitas demandas - abre uma porta interessante para discussão do sentido da participação popular na gestão pública para além da divisão dos valores de investimento e dos limites disto.

Stefani Henrique, coordenador do OP, expressa essa concepção de governo e anuncia algumas dificuldades e tensões dessa forma participativa:

Também é uma coisa que eu quero deixar bem claro: participação popular é mais do que o OP. [...] Participação popular é, por exemplo, tu destes um exemplo: os eventos de cultura, as oficinas de cultura. Participação popular é o governo ser um governo acessível. Você poder reunir com um secretário, você ter um secretário presente em uma reunião em uma comunidade, você poder ter conselho escolar, que você elege diretor, entendeu? Então, participação popular é muito mais do que o OP. Até porque o OP só discutia o investimento. Nós não discutíamos custeio, nós não chegamos a discutir [verba de] custeio, nós não chegamos a discutir [verba de pagamento de] pessoal.

[Essas políticas de cultura, de educação, de esporte e lazer... passavam pelo OP também?]

Não. Não, aí era secretaria de cultura. [...] Só que a secretaria de cultura tinha as suas estruturas de participação popular também [...], ela formava pessoas que administravam as atividades culturais em cada área. [...] [A participação popular era uma concepção de governo] Tanto que nas pesquisas de governo, nós tínhamos uma pergunta [...] [sobre qual] área do governo você reconhece que o governo atua mais. Participação popular

\footnotetext{
${ }^{29}$ Sandra Helena Cruz é professora do curso de Serviço Social da UFPA e foi presidente da Fundação Papa João XXXIII e coordenadora da marca "Dar um futuro às crianças".
} 
ganhava de saneamento, e tu sabes que o Edmilson, o nosso governo, fez muita obra na cidade, muita obra. E o primeiro item era a participação popular, que é uma coisa intangível, entendeu? Então, bolsa escola [aparecia] às vezes, ou era participação ou era bolsa escola ou era pavimentação, eram as três. Um mês era um, um mês era outro, mas era aquilo ali, quer dizer as pessoas percebiam [...] Tanto que o nosso lema era "Governo do Povo". E o do OP era "Construindo o poder popular". [...] Era aquilo que a gente queria, era organizar... 0 nosso objetivo era construir uma estrutura, autônoma, de poder popular que resistisse ao governo, ao fim do governo. (Stefani Henrique, entrevista concedida à pesquisadora, 04 de agosto de 2009).

É também esse peso e centralidade política que em certa medida desencadearam tensões dentro do próprio governo e na relação que este manteve com setores que lhe apoiavam e, mais abertamente e em confronto direto, com aqueles setores de oposição com os quais estava em franca divergência.

Essa dinâmica participativa instaurada nos fóruns internos das secretarias gerava desdobramentos na vida cotidiana dos órgãos públicos e do trabalho de seus técnicos e parte da resistência ao processo teve como questão a relação que se estabelecia entre os técnicos de carreira da prefeitura e essa nova orientação de democratização da máquina pública. Rita de Cássia, assistente da CRC, relata a tensão inicial que a nova dinâmica política instaurada com o OP gerou.

É, a partir do momento que houve essa definição política, que o prefeito chamou seu secretariado e estabeleceu essa decisão política... para gente [da CRC], para os conselheiros [do OP] ficou tranquila a relação com as secretarias [de governo]. Em um ou outro local a gente tinha assim uma resistência, principalmente dos técnicos de secretarias, como a de obras, de saúde também que, imagina, tinha anos de município, que não chegaram com o governo do Edmilson, já estavam ali há várias outras gestões e que nunca tiveram um morador a acompanhar [seu trabalho]; um arquiteto ter que acompanhar e ficar explicando para os moradores... Porque esses técnicos, antes de qualquer coisa, eles iam apresentar essa maquete para os 
moradores (Rita de Cássia, entrevista concedida à pesquisadora, 04 de dezembro de 2009).

Esse processo de abertura das estruturas de gestão à participação popular e as resistências encontradas expõem um aparato estatal pouco permeável às dinâmicas participativas, especialmente se temos em conta os setores populares da população e as amarras administrativas para esta participação. 0 que nos leva a colocar em pauta o peso da decisão da gestão em priorizar politicamente determinados arranjos institucionais que favorecem a abertura do Estado à participação dos setores populares no seu cotidiano ${ }^{30}$.

É possível afirmar que o governo municipal eleito tinha legitimidade política para introduzir mudanças na cultura política da máquina pública, que emanava da sua base de apoio popular para implantar o OP, como o fez, desde a posse do governo respondendo a demanda de criar mecanismos de participação efetivos na gestão da cidade. Entretanto, é preciso dizer que a situação desse governo em relação à Câmara Municipal e à chamada "governabilidade institucional" era muito diferente. A bancada eleita era bastante reduzida, perfazendo ao todo quatro vereadores da coligação do prefeito, do total de trinta e três vereadores. Se consideramos a base aliada, o governo chegou a contar com oito vereadores.

Essa configuração estabeleceu uma dinâmica, por outro lado, de mobilização e defesa popular do OP e de suas deliberações frente à Câmara de Vereadores, que queria ignorá-las. As formas de pressão do OP sobre a Câmara foram notadas diferentemente pelos setores que estavam na disputa, o que era esperado.

Foi logo instalado o OP, logo no primeiro semestre nós começamos a trabalhar e fazer meio que aos trancos e barrancos, mas na certeza de que o caminho era aquele. E foi interessante, eu acho que a sociedade ficou meio assustada com aquilo, uns não acreditavam, a gente foi crescendo ao longo dos anos. Mas aconteceu e a gente chegou no resultado e tal. E o governo tentou impor à Câmara a aceitação do orçamento como um todo porque o

\footnotetext{
${ }^{30}$ A partir da leitura dos dados da pesquisa sobre os orçamentos participativos em todo país, na gestão 1997 2000 (Ribeiro e Grazia, 2003), no que se refere a mudanças na administração decorrentes do OP, é possível dizer que as transformações na máquina pública tiveram pouco alcance assim como a articulação entre políticas setoriais se fizeram sentir timidamente se percebidas como mudanças induzidas pelos OP nos 103 municípios pesquisados. Essa avaliação corrobora a percepção de que a existência do instrumento não é em si capaz de reverter a lógica pouco permeável à participação popular nas cidades brasileiras.
} 
OP tinha sido feito e [isto] não era correto. Porque o OP opinava, digamos assim, discutia uma pequeníssima parte do orçamento, que eram os recursos advindos do IPTU, recursos da prefeitura [...] de tributação municipal, então era um valor de menos de $5 \%$ do orçamento. Mesmo que fosse $100 \%$, a Câmara como poder instituído tem a prerrogativa de votar. Quer dizer, claro que tem uma pressão maior ou menor, é legítima uma pressão da sociedade e daqueles que participaram, tem que pressionar a Câmara. Isso aí é necessário, o ideal é que tivesse já no nosso cotidiano, mas não está, eles [os vereadores] votam o orçamento lá e a gente nem sabe. Então nesse primeiro ano a Câmara chegou a ser invadida, e invadida mesmo pelos conselheiros do OP, pela turma comandada naturalmente pela Força [Socialista] e chegou a derrubar as paredes da Câmara, derrubaram... foi uma coisa horrível, foi uma confusão e não foi uma coisa legal, realmente, porque não faz parte do...não está correto isso. Nós temos que avançar, mas dentro do marco legal. Isso nos fragilizou. Não havia oposição, mas isso nos fragilizou dentro da Câmara porque como é que a gente iria defender o governo? ${ }^{31}$ Porque todos nós sabíamos que o governo estava por trás daquilo, que as forças políticas davam sustentação ao governo, e mesmo pessoas do governo, quer dizer, pessoas estavam no comando da invasão, da manifestação lá. Então ficou ruim para nós, esse foi o lado negativo. O lado positivo foi que [no] ano seguinte [...] as pessoas, majoritariamente de esquerda, menos de apoio da direita, [...] com o tempo começaram a se organizar para poderem participar também, começaram a aqui e ali, pontual, não majoritariamente, mas começaram a se organizar porque a própria população procurava (Valdir Cardoso ${ }^{32}$, entrevista concedida à pesquisadora, 9 de dezembro de 2009).

31 Valdir Cardoso retoma o episódio de votação do primeiro orçamento construído através do OP que foi entregue pelo governo Edmilson Rodrigues em 1997 para exercício em 1998. Na ocasião da votação, houve uma intensa mobilização dos participantes (delegados e participantes das assembleias territoriais) do OP para acompanhar a votação. Os manifestantes queriam a votação na íntegra do orçamento discutido e aprovado no OP, ao que a maior parte dos vereadores de Belém, fora, como dissemos, da base aliada do governo, se opunha. Os manifestantes foram impedidos de entrar no plenário da Câmara Municipal e deste impedimento gerou-se o tumulto a que se refere o vereador. Os jornais locais noticiaram fortemente a "invasão" da Câmara, acusando a prefeitura de utilizar-se desse mecanismo coercitivo para impor sua pauta e seu orçamento aos vereadores.

32 Valdir Cardoso é médico, ex-vereador de Belém pelo PPS, compôs a base do governo no segundo mandato de Edmilson Rodrigues, atualmente secretário da Federação Nacional dos Médicos e presidente do Sindicato do Médicos em Belém. A entrevista foi realizada em 9 de dezembro de 2009. 
As dificuldades de relação do Executivo com o Legislativo não são uma novidade, menos ainda para governos de corte democrático e popular. No entanto, não é demais retomar esse tema, uma vez que ele abre uma perspectiva importante e interessante a partir da qual é possível tratar das dificuldades de democratização da máquina administrativa brasileira, assim como pensar o papel do Estado na constituição de instrumentos de democratização dessa mesma máquina.

\section{Do OP ao Congresso da Cidade}

Em 1998, na metade do primeiro mandato, foi lançada publicamente pela administração municipal a proposta de implantação do Congresso da Cidade no lugar do OP. Apesar de ter sido lançado na metade da primeira gestão, o Congresso da Cidade foi estabelecido definitivamente em 2001, já no segundo mandato de Edmilson Rodrigues. Esse mecanismo participativo, assim como a forma de pensar a cidade, sua gestão e seu planejamento que lhe davam corpo, pretendia incorporar as contribuições e avanços do OP e superar suas limitações. A proposta do Congresso teve como centro organizador a necessidade de não somente efetuar a divisão dos recursos municipais através do OP, mas intentava inaugurar uma nova forma de gestão da cidade, incorporando ao debate sobre o orçamento municipal, gestado pela população através do OP, "as instâncias de controle social num único processo" (Rodrigues, 2002: 34).

O Congresso da Cidade, nessa perspectiva, não seria apenas um evento de inauguração ou de fechamento do processo de discussão do orçamento municipal, e sim um processo de mobilização social e de discussão dos rumos da cidade através de assembleias territoriais, plenárias temáticas, fóruns e congressos temáticos, distritais e municipais, que culminariam então na instância máxima de deliberação pública - o próprio Congresso da Cidade, a partir do qual eram eleitos os delegados ao Conselho da Cidade. Além do processo congressual em si, que à semelhança do OP, reiniciava-se a cada ano, instituía-se em Belém mecanismos e instâncias de controle social tanto das obras estrito senso (o que já acontecia com o OP) quanto da condução dos programas e políticas deliberadas pelo Congresso, em âmbito distrital e municipal. 
A pretendida superação do OP tinha como perspectiva para os dirigentes à frente da administração de Belém, a construção de um "projeto estratégico de desenvolvimento" para a cidade, cujos eixos políticos eram a) participação popular com controle social; b) novos valores na perspectiva do socialismo, c) inversão de prioridades e acesso à cidade; d) combate ao neoliberalismo, defesa da soberania nacional e afirmação do poder popular; e) fortalecimento dos movimentos sociais e organizações populares; f) desenvolvimento local, articulando estratégia nacional e regional; g) "aprofundamento do processo de refundação de Belém com vistas a consolidar a construção de uma cidade a partir de sua identidade cultural"; h) valorização do serviço e do servidor público; e i) informação como instrumento de democratização do poder, da participação e do planejamento da cidade (Rodrigues, 2002: 9-10).

É importante notar que essa conjugação entre eixos políticos gerais e formas de ação e de participação popular está enraizada na percepção e reconhecimento das desigualdades vivenciadas pela população de Belém ao longo de sua história, repostas na atualidade. Ou seja, a percepção de que os mecanismos de controle social e participação popular no contexto de uma economia capitalista e, ainda mais, no contexto de uma cidade periférica num país também periférico, impõem a necessidade de avaliar e pesar os limites das formas de participação aclamadas como democratizantes. De algum maneira, essa formulação recoloca em destaque e aprofunda a concepção que orienta a constituição do OP como mecanismo de participação popular em Belém.

0 reconhecimento das desigualdades estruturais da cidade e o entendimento que elas não serão "corrigidas" por esses mecanismos (por mais que eles sejam necessários no sentido de democratizar a vida pública), e sim pela superação do modo de produção, colocam em perspectiva esses processos de controle e apropriação da gestão municipal, na medida mesma em que estão articulados a uma visão política estratégica. Por isto, a crítica ao OP e a identificação de suas limitações extrapolam a constatação de impossibilidade ou de pouca "eficiência" da participação e do controle populares na gestão da cidade, numa tentativa de fugir à gestão das precariedades.

A passagem do OP para o Congresso da Cidade, apesar do longo tempo de gestação da ideia, foi bastante controversa e, segundo alguns interlocutores, não se fez sem perdas significativas para a natureza e qualidade da experiência participativa na cidade. 
A primeira controvérsia diz respeito ao próprio enunciador da mudança: a reorientação do OP para Congresso surge de dentro do próprio governo. Tal medida, ainda que tomada como legítima na medida que o governo não deixava de se posicionar nos debates do e sobre o OP, foi percebida por alguns setores como uma quebra do acordo e do acúmulo político em construção naquele momento que causou, além de tensão e disputas, uma certa confusão, dado que o Congresso da Cidade envolvia mais etapas e uma dinâmica mais complexa.

Não foi muito tranquila [a passagem do OP para Congresso da Cidade] para os conselheiros, né? Havia pouca compreensão do que viria com o congresso da cidade, né? Então, os conselheiros fizeram críticas e defenderam propostas de não passagem para esse outro momento que seria o Congresso da Cidade. Não tiveram a compreensão de defender uma proposta do Congresso da Cidade. Logicamente foi o governo e que não foi aceita assim a $100 \%$ pelos conselheiros... E havia muita, muita defesa de que o OP ele era o avanço, que ele era o avanço da gestão democrática, [por parte] do movimento popular, do movimento social. E a chegada do Congresso da Cidade foi muito tensa, né? (Rita de Cássia, entrevista concedida à pesquisadora, 04 de agosto de 2009).

A ideia da transformação do OP em Congresso, apesar de discutida nas plenárias e no próprio COP, foi lançada pela administração e não partiu de uma demanda popular ou mesmo de um setor organizado específico do movimento de moradia, de base popular ou sindical. Esse fato reacende o debate sobre a real capacidade da experiência participativa na gestão municipal se entranhar na prática política e nas formas de sociabilidade política dos setores populares em Belém, a ponto de que esta se configure em um polo ativo na sua própria concepção, em contraposição ao Estado.

Bem, essa discussão para mudar para Congresso da Cidade, foi uma experiência que a gente foi comunicado porque não teve uma discussão maior sobre por que sair do OP para Congresso da Cidade. Porque saía de uma experiência de OP de mobilização de massa e nessa mobilização de massa, trazendo os desorganizados, você cria uma série de expectativas porque trás um pessoal para a assembleia, as pessoas vêm com expectativas 
de trazer coisas muito miúdas e o retorno para essas pessoas era muito lento. [...] Aí a gente saiu do OP para o Congresso da Cidade e na minha opinião, talvez não haja consenso com relação a isso, mas na minha opinião eu acho que nós fomos, o conselho ficou muito tutelado, um apêndice da secretaria de planejamento... (Aldalice Otterloo ${ }^{33}$, entrevista concedida à pesquisadora, 03 de dezembro de 2009).

Por outro lado, as tensões e dificuldades de compreensão (ou de concordância) desta transformação assentam-se justamente na leitura dos méritos que o OP alcançou. Dito de outra maneira, é possível reconhecer que o OP firmou-se como instrumento de participação e mobilização popular na cidade - o que pode ser confirmado pelos números crescentes de participação ano a ano nas plenárias e assembleias, assim como através da força e da forma virulenta como suas instâncias eram reportadas nos jornais na cidade, especialmente por $O$ Liberal. Articulada à participação quantitativa, há uma percepção generalizada de que o OP disseminou-se como uma experiência política que alcançava estratos e/ou segmentos da população da cidade que não estavam organizados em movimentos sociais e cujas demandas pautavam-se pelas carências do cotidiano imediato, com pouca capacidade de interlocução com o planejamento da cidade visto de uma perspectiva integrada.

Porque partiu de uma premissa correta que o OP traz demandas sociais, da dívida social e que gente precisava trabalhar a cidade do futuro. 0 que vai ser Belém daqui a vinte anos? Correto. Então a gente precisava ter um espaço maior para ambas as plenárias, ou reforço às plenárias, enfim... Precisava ter um processo no qual o peso de discutir Belém do futuro fosse maior ou igual às demandas sociais. 0 problema todo é que a nossa cidade tinha $70 \%$ da área sem urbanização, entendeu? Então eu argumentava dentro do governo, a premissa está correta, o problema é que a pressão da obra localizada é muito grande, porque não é igual a Porto Alegre que na década de 1980, já era tida como umas das cidades com as melhores condições de vida. [...] Você dá um giro de cento e oitenta graus, tá, e você implanta um processo difícil de entender, com um nome que lembra evento,

\footnotetext{
33 Aldalice Moura da Cruz Otterloo é educadora, coordenadora da entidade Instituto Universidade Popular (Unipop) que atua junto aos movimentos populares em Belém desde 1985 e foi representante da Associação Brasileira de ONGs (Abong) no Congresso da Cidade.
} 
Congresso da Cidade lembra evento, não isso? Não é a primeira coisa que vem na cabeça? Ninguém entendia. A síntese do que as pessoas falavam era assim, Congresso da Cidade é tudo que o governo faz, tá. Mas tudo é um negócio muito abstrato, né, é muito abstrato. [...] Começou a ter o problema da participação popular, porque o que alimentava o povo era a demanda localizada. Quando eles chegavam no OP, nós dizíamos "mas espera aí, não tem só a sua rua para debater. Tem a tua rua. Mas tem o [mercado] Ver-oPeso, tem não sei o que, não sei o quê”... e assim foi. Então a gente usava a demanda localizada para trazer o cara, que era o que mobilizava ele, mas aqui a gente debatia outras coisas, entendeu? [...] Começou a se priorizar as obras da cidade, mas o cara não se mobilizava, vamos dizer assim... o Ver-oPeso até que é um símbolo da nossa cidade, o Ver-o-Peso já estava resolvido... Mas o Memorial dos Povos, ninguém se mobilizava para isso, eu não vou sair da minha casa para pisar na lama para defender o Memorial dos Povos, entendeu? (Stefani Henrique, entrevista concedida à pesquisadora, 4 de agosto de 2009).

Este comentário de um dos principais articuladores do OP e críticos do Congresso dá notícias do que era a divergência: os limites de publicização das demandas e carências históricas acumuladas e sua capacidade de, a partir dessa realidade, politizar a vida, as necessidades, conferindo-lhes significado no âmbito de um projeto de futuro e de sociedade, de subjetivação política. O OP - aqui em Belém e também em outras cidades do país - reencontra sua tensão primeira

Em Belém, mais especificamente, a transformação do locus de participação popular do OP em Congresso da Cidade apontava a alargamento ou aprofundamento de uma perspectiva política e desta maneira, era uma aposta. Sobre esta aposta e seus desdobramentos que trataremos no próximo capítulo. Uma questão nos guiará: a busca por aquilo que o Congresso da Cidade, compreendido em sua especificidade e diferença em relação aos outros processos decisórios brasileiros, revela sobre o próprio Brasil. 
capítulo 4

\section{Congresso da Cidade em Belém (2001-2004)}

Vivendo, se aprende; mas o que se aprende, mais, é só a fazer outras maiores perguntas. Riobaldo, em Grande Sertão: Veredas

O Congresso da Cidade está em linha de continuidade e, ao mesmo tempo, de ruptura com o OP. Os documentos e falas colhidos dão conta de uma transformação profunda operada pelo governo no seu principal mecanismo de participação popular e gestão partilhada da cidade.

A construção do Congresso da Cidade como forma de debate público sobre a cidade estendeu-se por três anos, antes de sua efetiva instauração no ano de 2001 e durante o qual um conjunto de atividades e eventos aconteceram com o intuito de "preparar o terreno para o advento do Congresso da Cidade" (PMB, 2004: 3). Em abril de 1998, com o seminário "Marca da Participação Popular" é apresentada a ideia do congresso que, durante os seis meses seguintes de visitas e consultas, seria formatada e lançada em agosto, como uma "proposta de construção". Finalmente, em outubro de 1998, é lançado publicamente o Congresso da Cidade, “como um projeto para tornar Belém uma 'Metrópole das Luzes', com os diversos grupos sociais sendo artífices da construção social de sua própria cidadania" (PMB, 2004: 4).

Daí até outubro de 2001, quando se instala o I Congresso Geral da Cidade, teve lugar em Belém uma série de atividades preparatórias de debate sobre a cidade, de diferentes perspectivas. Além desses debates, instaurou-se nesse período formas de gestão de espaços e/ou de projetos, como o colóquio sobre o Centro Histórico que instaurou o condomínio participativo da Rua João Alfredo ou ainda os comitês ambientais. 0 ano de 2001, o então 
reempossado Edmilson Rodrigues marca o início das atividades congressuais, com a realização do I Congresso Municipal de Direitos Humanos, para maio, com a participação de diversos setores, grupos sociais, entidades e movimentos.

Essa mudança dos/nos mecanismos de planejamento municipal trazia para o centro do debate os limites já identificados no OP logo após sua instauração e também relatados em parte da bibliografia sobre OPs ${ }^{1}$.

Nesse aspecto eu acho que tem razão os que avaliam como um salto de qualidade a mudança de OP para Congresso da Cidade, pelo fato de que o OP ficava muito restrito à formulação de demandas pra atendimento, em termos de políticas públicas, de forma compartimentalizada, sem uma visão global do financiamento da cidade, da poupança social existente pra ser distribuída, pra ser rateada entre pagamento de pessoal, investimentos, custeio da máquina. [...] Então, é essa necessidade de mediar o atendimento das demandas concretas, portanto investimentos e priorização de recursos pra essas demandas sociais, ao mesmo tempo em que você não se limita a isso. [...] Neste sentido, o Congresso da Cidade - mais do que a experiência inicial do OP - se prestava a essa visão mais global, mais totalizante da cidade, das questões políticas, sem poder abrir mão de ser também um espaço pra sistematização de demandas sociais locais e sua concretização, seu atendimento concreto (Aldenor Araújo Jr, entrevista concedida à pesquisadora, 02 de dezembro de 2012).

Se é verdade que a tensão com o OP surge de suas virtuosidades - ou seja, surge justamente porque o OP e seus fóruns se espraiaram e em certa medida, constituíram-se como mecanismos de fato de debate sobre a cidade, olhada e disputada a partir das carências cotidianas daquela população que foi ao seus fóruns -, é possível identificar claramente esses limites e fazer a crítica aos mecanismos de gestão participativa.

$\mathrm{O}$ OP, quando o Edmilson ganhou a gestão do município de Belém, chamou o povo pra questão de ver o que você poderia fazer com o orçamento. E o Congresso foi diferente, ele chamou todos os movimentos pra já pegar o

\footnotetext{
${ }^{1}$ Para este debate sobre os OPs ver Avritzer (2004), Dagnino (2002), Bello (2007) e Rizek (2007). Ver também o recente número da revista Lua Nova (n.85, 2012).
} 
orçamento e investir no que você quer que seja feito. Primeiro houve uma discussão onde foram criadas algumas secretarias porque havia necessidade. Aí depois, sim, chamou todos os segmentos: culturais, sociais, saúde, educação... Todo mundo veio. E o Congresso foi mais abrangente do que o OP porque vieram todos os segmentos. No tempo do Orçamento, não (Inês Barbosa², entrevista concedida à pesquisadora, 08 de dezembro de 2009).

Contudo, antes de ratificarmos essa perspectiva de análise - aliás, identificada e corroborada pela percepção que os próprios participantes do OP expressam do processo -, é necessário referir essa mudança ao seu contexto e informá-la de seus pressupostos.

\section{Qual a aposta política expressa no Congresso da Cidade? Como se aposta?}

O Congresso da Cidade pode ser qualificado como aprofundamento das diretrizes programáticas expressas no programa de governo e, do mesmo modo, uma elaboração crítica sobre a dinâmica política que se instaurou na cidade nos primeiros anos da gestão 1997-2000. Cabe dizer que, assim como na primeira eleição, o tema gestão democrática e controle social figura no primeiro item do programa de governo e é reafirmado como o centro político da proposta para Belém. As mudanças entre esses dois momentos refletemse na maneira através da qual a gestão irá conduzir a implantação de mecanismos participativos, assim como na experiência propriamente dita que se desenvolveu durante as gestões.

Duas linhas de perspectiva conduzem e estruturam a formulação do Congresso da Cidade: cidade e cultura. A nomeação desse instrumento participativo chama atenção. A qualificação dessa dinâmica como "congresso", um fórum permanente de elaboração política e metaforicamente acima da Câmara Municipal, indica a centralidade que ele terá para o conjunto da prefeitura. Por outro lado, a qualificação desse planejamento como "da

\footnotetext{
2 Inês Barbosa é líder comunitária do bairro da Cabanagem, construiu em sua casa uma biblioteca comunitária, que durante o governo Edmilson Rodrigues recebeu o projeto Mala de Livros e hoje se mantém sem recursos públicos. A entrevista foi feita na biblioteca em 8 de dezembro de 2009.
} 
cidade" parece apontar para o reconhecimento do município como um espaço privilegiado dos conflitos e contradições sociais. A cidade, cenário no qual se desenrolam as lutas sociais, cumpre então papel primordial nessas lutas que, por sua vez, não são abstratas, formam e são formadas por uma e em uma cidade concreta ${ }^{3}$.

Ao debruçar-se sobre o planejamento da cidade, ao reconhecer as diferenças que nela convivem, que a fertilizam e também as imensas desigualdades que lhe atravessam, ao resgatar a tradição cultural e simbólica de seus povos e tomar a cidade como lugar de conflitos, a administração municipal de Belém traz a luz pública e incita a população a repensar e refazer o vínculo entre cidade e política. A cidade, nessa perspectiva, carrega a possibilidade de publicização desses conflitos e disputas por seus sentidos, desde uma perspectiva de seus sujeitos, operando um deslocamento de sentidos estabelecidos; é nesta cidade conflitiva onde se construirá a possibilidade de liberdade (Rancière, 1998).

Parte dessa disputa material e simbólica pelos sentidos e destinos da cidade de Belém, expressou-se no Congresso da Cidade com a afluência de segmentos e grupos, movimentos e setores populares que, na mobilização e nos debates, puderam verbalizar suas posições, construir coletivamente um projeto de futuro para a cidade, articuladas a suas demandas, e neste movimento, constituir-se como sujeitos.

É verdade que setores da oposição dessa proposta política, as elites econômicas e políticas de Belém e do Pará, não tomaram parte efetivamente nesse espaço de debate sobre a cidade através de seus fóruns e/ou formas de representação setorial, apesar de terem garantidas cadeiras no Congresso através de seus órgãos de representação de classe. Tal situação não significa que não consideraram a existência desse mecanismo4 . Contudo, é possível dizer, a partir dos relatos colhidos, que uma parte da oposição menos programática ao governo e à proposta política encarnados nessa gestão, setores ligados aos vereadores que não necessariamente compunham um bloco de classe e tampouco estavam na base do

\footnotetext{
3 É explicita nos documentos públicos veiculados pela administração de Belém (1997-2004) que tratam de sua compreensão e sua concepção do papel da cidade, a influência de autores como Henri Lefèbvre, Milton Santos e de Carlos Vainer (2000), em especial a mais recente produção crítica deste último, sobre planejamento estratégico e as intervenções culturais e urbanas em âmbito mundial e nacional.

${ }^{4}$ Esta discussão será retomada num ponto especifico à frente. Por hora, é importante marcar que essa não participação indica, por sua vez, uma maneira de compreender e se posicionar frente à experiência política na cidade e, portanto, revela o lugar imputado aos segmentos populares que para lá afluíram, pela elite econômica e política do estado e da cidade. Lemos aqui o silenciamento da participação política e das formas de expressão cultural como um ato político popular de invisibilizar esta parcela da população.
} 
governo, participaram lateralmente do Congresso da Cidade, usando seus espaços de debate e de apresentação das demandas para garantir conquistas (obras locais, especialmente) para sua base eleitoral.

A cultura dos oprimidos, para usar uma expressão de Walter Benjamin, e a reivindicação da história cabana são centrais nessa disputa política e na construção de uma fala dissensual ${ }^{5}$ em Belém. Não é sem intenção e consequência que o espaço onde se desenvolvem as atividades gerais do Congresso é a Aldeia Cabana - uma estrutura urbana projetada e construída na primeira administração de Edmilson Rodrigues, que abrigaria as atividades do Congresso da Cidade e também outras atividades de educação, cultura e lazer fomentadas e realizadas pela prefeitura.

Para além de espaços como o da Aldeia Cabana que marcam simbolicamente a constituição de uma nova dinâmica urbana e política em Belém, vale a pena chamar atenção para o conjunto de intervenções urbanas que vincularam (ou ressaltaram) à cidade atividades ou expressões de cultura que, nessa matriz de planejamento, foram consideradas obras estruturantes. Belém, também conhecida como cidade das águas, é banhada por dois imensos rios e está localizada, como já afirmamos, na foz expandida do Amazonas. Parte de sua vida econômica está vinculada ao ciclo das águas e é pelos rios que se transporta parte significativa da produção econômica tradicional, como o açaí e o pescado. Através dos rios Guamá e Acará, as ilhas do interior e os povoados próximos à cidade interligam-se, suas gentes vão e vem, vendem e compram produtos, acessam serviços públicos na capital, estabelecem e constroem laços. É ali, nessa orla, espaço de encontro por excelência, que a

\footnotetext{
${ }^{5}$ Suponho aqui que esse projeto político foi assumido por uma parte significativa dos movimentos sociais populares e, em certo sentido, por parte da população que participou do Congresso da Cidade. Desse modo, a aposta concernida nesse mecanismo deixa de ser um atributo exclusivo do governo e se incorpora, em maior ou menor grau, ao conjunto de experiência e elaboração desse campo popular. Isto não elimina o fato - e as tensões - de que o Congresso da Cidade, bem como o OP,é fruto de uma orientação de governo. A rigor, na formulação de Jacques Rancière não seria possível uma fala dissensual que partisse de uma estrutura de Estado; para ele, uma fala dissensual constitui-se como processo de subjetivação política, uma situação de fala e de desentendimento: "Por desentendimento entenderemos um tipo determinado de situação de palavra: aquela que um dos interlocutores ao mesmo tempo entende e não entende o que diz o outro. 0 desentendimento não é um conflito entre aquele que diz branco e aquele que diz preto. É o conflito entre aquele que diz branco e aquele que diz branco mas não entende a mesma coisa, ou não entende de modo nenhum que o outro diz a mesma coisa com o nome de brancura. [...] Os casos de desentendimento são aqueles em que a disputa sobre o que quer dizer falar constitui a própria racionalidade da situação de palavra" (Rancière, 1996: 11-12).
} 
cidade ribeirinha pulsa mais forte, construindo e reelaborando - material e simbolicamente - seus modos de vida e sua cultura.

Os projetos apresentados no Congresso da Cidade, tanto no âmbito das propostas defendidas pela prefeitura quanto das reivindicadas por movimentos sociais como obras estruturantes $^{6}$, dão visibilidade à vida ribeirinha, por assim dizer, conjugando a retomada da orla às atividades cotidianas, de trabalho e de lazer ${ }^{7}$. Abrindo novamente a cidade para suas águas, pode-se nesses lugares redescobertos tomar contato novamente com os rios, suas gentes, tradições e culturas, afirmando-as como legítimas e pertencentes à cidade. 0 Projeto Ver-o-Rio ${ }^{8}$ é um emblema desse tipo de atuação urbana-cultural.

Bom, foi que a gente sempre teve essas coisas lá na aldeia. 0 antigo sistema era a pessoa mais idosa fazia parte como conselheiro. Então, eu era conselheiro na cidade. Eu tinha a suplente que era a Suzana Caripuna, e assim nós nos articulamos, eu com a Suzana, quando era alguma participação de projetos que eram criados juntos com a sociedade organizada de Belém, era tudo entrosado. A pena é que muitas coisas nós criamos na casa dos índios [e se perderam na gestão Dulciomar Costa]. No Ver-o-Rio, [no Memorial dos Povos Indígenas] aquele foi o nosso projeto indígena na cidade. Porque nós nos articulamos com a sociedade e aí foi

\footnotetext{
${ }^{6}$ As discussões no Congresso da Cidade eram organizadas a partir de seis eixos temáticos: gestão democrática e qualidade de vida, cidadania cultural, urbanístico e ambiental, economia solidária, inclusão social, direitos humanos (negros, índios, mulher, portadores de deficiência, homossexuais). Cada eixo articulava diversas ações através das políticas públicas, envolvendo secretarias e órgãos municipais, nos seguintes setores: planejamento e gestão, urbanismo, habitação, saneamento, meio ambiente, transporte, economia, turismo, administração tributária, saúde, educação, assistência social, cultura, comunicação, lazer. Destes setores de ação apenas estão listados em todos os eixos temáticos: planejamento/gestão e cultura. Retomo estes aspectos operativos do Congresso da Cidade mais à frente neste capítulo.

7 Naquele período a reestruturação urbana na orla e as intervenções nas bacias hidrográficas da cidade estiveram reunidas num programa articulado de ações de sob o nome de Programa de Recuperação de Rios Urbanos de Belém, que contava com apoio financeiro e técnico do Programa de Gestão Urbana da ONU, desde 1999. As intervenções articuladas nesse programa foram debatidas no Congresso da Cidade e abrangiam desde ações como a recuperação do Mercado Ver-o-Peso e intervenções de saneamento básico e construção de moradia em áreas de baixadas na cidade, passando pela intervenção na Porta da Praça da Princesa Izabel e Praça do Pescador, Macrodrenagem da Bacia do Tucunduba entre outras.

8 "Como parte da estratégia de recuperação de áreas da orla da cidade para a utilização pública, a criação do complexo Ver-o-Rio talvez tenha sido uma das maiores vitórias. Os $12.500 \mathrm{~m}^{2}$, desobstruídos e urbanizados, envolve vários programas de inclusão social como a utilização das cabanas de vendas de comidas típicas que são feitos pela Cooperativa de Famílias do Programa Bolsa-Escola através do Programa de Geração de Emprego e Renda, financiado pelo Banco do Povo. O Memorial dos Povos Indígenas foi deliberado no Congresso da Cidade e inaugurado em 2003 garantindo com isto um espaço para a reafirmação da identidade da nossa cidade. Neste sentido que também foi lançada a pedra fundamental do Memorial dos Povos AfroBrasileiros" (PMB, 2004)
} 
aprovado pela maioria dos conselheiros, e foi estipulado o valor de duzentos mil nessa faixa... E foi criado. E nós inauguramos. Foi com uma inauguração, foi com várias manifestações dos índios. Convidamos os índios da aldeia. E foi muito bonito. Teve festa, dança, tudo (Emílio Kabá, entrevista concedida à pesquisadora, 04 de agosto de 2009).

Esse processo de resgate e de afirmação cultural é uma via de mão dupla. Trata-se de um movimento pra "dentro" no sentido que se orienta por e para afirmação de uma determinada tradição cultural e seus modos de vida e, portanto, de incidência e diálogo com aqueles que compõem esse grupo e são seus sujeitos. Ao mesmo tempo, dirige-se para o conjunto da cidade, buscando dar ciência do pertencimento e da importância das tradições que compõem sua história comum, assegurando a existência dos modos de ser, viver e pensar de grupos e sujeitos sistemática e violentamente invisibilizados. Há que se notar o sentido de resistência que a cultura opera nessa perspectiva; aqui, a cultura é um ato de subjetivação política.

Vivendo numa cidade desigual e pobre, com uma tradição de lutas e revoltas populares silenciadas, com acento da tradição e herança indígena e cabocla (ainda que sempre renegada e, muitas vezes, posta no esquecimento), a afirmação de uma identidade cultural da cidade cumpriu (quiçá, cumpre, no presente) papel fundamental no processo de explicitação dos conflitos e de afirmação de um futuro com acento popular.

0 resgate das histórias e contribuições dos negros, dos indígenas de diversas etnias, dos ribeirinhos, dos caboclos, dos quilombolas, dos pobres e explorados recebeu especial tratamento por parte da administração municipal na montagem de uma identidade política e programática que procurava, através da cultura e das contribuições diversas para a formação da população paraense, afirmar um polo político popular de sustentação e legitimação daquela gestão.

Essa aposta se traduzia em uma política cultural para a cidade marcada pela abertura de espaços para aparecimento dos artistas locais, o fomento e estímulo para divulgação e financiamento de diversas formas de expressão artística, a exemplo dos festivais de música e da lei de incentivo à publicação da literatura paraense. Contudo, o que mais parece interessar, justamente pelo seu caráter ordinário, é a abertura de espaços públicos para 
manifestação artística em toda a cidade - especialmente na periferia, numa ação combinada entre a construção e/ou reforma de espaços públicos como praças e empreendimentos específicos (muitos discutidos no OP e no Congresso da Cidade) e uma ação de fomento cultural.

Tem uma coisa que os opositores diziam que era que o Edmilson construía muita praça! Mas praça é importante pra população, principalmente quando se leva cultura e tudo mais, lazer, essa coisa toda. [...] Assim, as praças eram espaços que estavam obsoletos, abandonados e tal. E construíam-se as praças e dentro dessa construção vinham os projetos implementados através de emendas e tudo. A [vereadora] Marinor [Brito], através de uma emenda [...] após a inauguração do Ver-o-Rio, criou um projeto chamado Canto Cabano lá no Ver-o-Rio. Então, todo final de tarde do domingo, uma hora dessas, nós estávamos nos preparando porque começava umas dezoito horas, dezessete horas, e ia até onze horas da noite, dez horas. [...] 0 Canto Cabano era música e poesia, música e literatura junto. [...] Era um espaço em que os artistas já tinham até a esperança de que se fosse fazer alguma coisa, que esse artista fosse fazer. [...] E o Canto Cabano era um desses projetos de estímulo ao artista e que oferecia à população algo de qualidade, atrações artísticas de qualidade. Eu tô falando por uma linha de trabalho [literatura], mas tem outras linhas, outros segmentos de cultura de que a gente não faz parte, até por causa da nossa linha de trabalho, nosso próprio prazer de fazer arte de um outro modo... Mas, assim, dentro do governo do Edmilson, todos os segmentos tinham espaço. Foram criados projetos também como o Cinema da Rua. [...] Em que o artista de cinema, o cineasta, o cara que produzia um clipe, um vídeo, qualquer pessoa do segmento de audiovisual, fazia a população trabalhar junto com eles fazendo uma tese e tal. Eu esqueci o nome desse projeto, era muito bonito (Renato Gusmão9, entrevista concedida à pesquisadora, agosto de 2009).

Essa ação cultural esteve combinada e foi ela mesma um ato de afirmação política, cujo mote centrava-se no resgate das tradições culturais dos povos que constituíram o povo

\footnotetext{
${ }^{9}$ Renato Gusmão é escritor e poeta, além de escrever, trabalha funcionário dos Correios e participou do Congresso da Cidade desde seu distrito.
} 
paraense, seus saberes e lutas. Assim, as tradições culturais foram lidas na sua dimensão de resistência e de luta política dos diversos povos e grupos.

A Revolução Cabana foi tomada desta maneira não como uma revolta a ser lembrada, um passado petrificado e distante; ela estruturava e conferia centralidade à constituição de um referencial de luta e resistência política que se queria afirmar e fomentar em Belém. Era um passado sobre o qual se debruçava e sobre o qual se elaborava, não para conhecê-lo "como ele de fato foi", mas como para pensar o presente.

É interessante perceber como aqui se articulam tradições políticas diversas e que, mais das vezes, estiveram separadas. Essa elaboração da Cabanagem (e suas decorrências para o conjunto da experiência em questão) parece dialogar e embeber-se do "dom de despertar no passado as centelhas da esperança" (Benjamim, 1996: 224) - concepção ancorada num corpus marxista, cujo horizonte utópico é o socialismo e, portanto, referida ao campo epistemológico e axiológico ocidental moderno. Não obstante, o projeto posto em movimento em Belém alimentava-se de tradições de povos e segmentos que não estavam referidos e nem postulavam como seu este conjunto de elaborações e menos ainda esses marcos teóricos.

Dessa aposta política emerge uma elaboração da formação social brasileira coordenada à reafirmação (ou reelaboração, mais precisamente) do horizonte socialista. Essa elaboração sobre os sujeitos políticos da transformação social reconhece como parte fundamental aqueles grupos e segmentos que não estão alinhados, desde o ponto de vista de sua concepção de mundo e seus modos de vida, com esse quadro referencial moderno. 0 reconhecimento de sua potência política e de seu papel na constituição de uma sociedade "livre, justa e fraterna" só pode se dar na medida do reconhecimento que esses grupos sociais não modernos não serão colonizados pela modernidade ou pelo desenvolvimento. Significa apontar para a compreensão do povo como múltiplo e diverso, mas nem por isto fragmentado - talvez aqui a impossibilidade de existir segundo sua maneira de compreender a vida e a violência desse silenciamento seja o elo ou o elemento comum nessa diversidade de sujeitos.

Para a tradição conservadora de pensamento brasileiro, esses segmentos foram, e são ainda, considerados como a margem, o empecilho e o excesso na conformação modernizadora da sociedade brasileira, assim como assim como, para uma determinada (e 
ainda majoritária) tradição de esquerda, foram considerados como agentes laterais (ou mesmo subsidiários e residuais) da transformação radical da vida social.

Se podemos concordar com Benjamim e sua elaboração sobre a história, quando afirma que "articular historicamente o passado não significa conhecê-lo 'como ele de fato foi'. Significa apropriar-se de uma reminiscência, tal como ela lampeja no momento de um perigo" (1996: 224), é possível reconhecer que a emergência da Cabanagem ou da Revolução Cabana como os textos da PMB usualmente a nomeiam, está informada por um projeto político de afirmação de um polo popular e, ao mesmo tempo, de um projeto de transformação social, no qual a cultura é um elemento político (ou de subjetivação política) no coração do Congresso da Cidade.

A Cabanagem não foi uma "revolução modelar". Ao contrário da luta de Sandino ou Martí, não possuía um corpo definido de ideias nem tampouco teve líderes como um Zumbi ou Zapata. No cenário latino-americano, a analogia mais próxima se encontra na Revolução Haitiana no início do século XIX, onde os negros escravos após baterem os exércitos de Napoleão, conquistaram a Independência e o poder, que dramaticamente deixaram escorregar pelas mãos. Apesar disto, como recorda João José Reis no seu livro A Rebelião Escrava, não havia no Brasil um senhor de negros que não estremecesse quando ouvia a palavra Haiti ou Ilha de São Domingos. Da mesma forma aqueles que se julgam donos da história buscaram durante mais de um século que a palavra Cabanagem não fosse pronunciada pelo povo e sua memória deformada ou esquecida. E, sem dúvida nenhuma, eles têm bons motivos para proceder assim.

A Revolução Cabana evoca principalmente a unidade dos oprimidos e explorados, sua capacidade em criar um vasto movimento revolucionário, que, de armas na mão, apeou os poderosos do governo e com estas mesmas armas, defendeu o seu próprio poder, o reconquistou e resistiu durante longos anos contra as tropas de um Império continental. São razões de sobra para assumirmos com respeito e orgulho a condição de novos cabanos (Campos, s/d). 
A percepção desta disputa é tão mais significativa se sabemos que a Cabanagem já havia sido acionada em outros momentos e por outros setores como referência e esteio políticos, sendo a mais recente operada por Jader Barbalho na sua administração frente ao Governo do Estado, entre 1983-1986. A disputa pelos sentidos da Revolta Cabana estava em pauta em Belém e no Pará desde algum tempo, remontando ao final do século XIX, com a publicação em 1865 do estudo de Domingos Antonio Raiol, ou o Barão de Guajará, como chama atenção Magda Ricci (2007), resurgindo na década de $1930^{10}$, por ocasião das comemorações do centenário da Cabanagem e estendendo-se até nosso tempo, alimentada por questões do seu tempo ${ }^{11}$.

Essa diretriz política de afirmação da Cabanagem foi incorporada à administração de tal maneira que a gestão utilizava expressões como "governo cabano", "prefeito cabano", "cidade cabana" em seus documentos internos e de comunicação social, firmando uma marca que poderia ser reconhecida por seus interlocutores. Esse resgate do movimento e de afirmação de uma mística cabana encontrou pela frente décadas de trabalho de "apagamento dos rastros" (Hardman, 1998) e de esquecimento, o que em certa medida, justifica em parte a sensação de pouca "efetividade" de afirmação. Interessa dizer que é possível ainda identificar que a associação entre a figura do prefeito Edmilson Rodrigues e

\footnotetext{
10 Leandro Lima, em sua dissertação de mestrado, aponta que, por ocasião do centenário da Cabanagem, duas vertentes historiográficas se apresentavam e disputam os sentidos do movimento. De um lado, a "tradição vinculada à memória dos vencedores" e, de outro, "a tradição vinculada à memória dos vencidos; uma disputa que consiste na afirmação de atributos negativos ou positivos ao cabano". 0 autor segue argumentando que tal disputa se organizava em torno de "marcos cronológicos" distintos na leitura da Cabanagem. A primeira vertente tinha em Jorge Hurley sua principal referência. Em um texto publicado em 1936, esse autor reivindicava a tomada da cidade de Belém pelos legalistas em 13 de maio de 1836, como a data a ser lembrada uma vez que simbolizava a retomada da cidade das mãos dos cabanos. "O segundo deles, é associado à memória dos vencidos. 0 "7 de janeiro de 1835" (data da primeira tomada rebelde da cidade), como marco comemorativo, foi ressaltado por Caio Prado Jr (1933), e sedimentou-se plenamente nas comemorações do sesquicentenário da revolta, em autores como Di Paolo (1986) e Chiavenato (1984)" (Lima, 2008: 24).

110 debate sobre a Cabanagem é extenso e multifacetado, além de ser feito em diversas esferas e não caberia neste espaço recompor seus passos. Destacamos, porém, que parte da recente recuperação do tema no campo da historiografia e mesmo da antropologia tem posto em questão as formas de nomeação e consideração dessa revolta. Atenção especial tem sido dada à investigação sobre o perfil social dos cabanos e sua motivação para a luta, implicando num claro reexame da classificação e filiação da Cabanagem. Certamente esse reexame tem ligações com o campo político, com a vida ordinária. A dissertação de Mário Barbosa (2004) busca recuperar essas filiações e os nexos entre a discussão historiográfica e o quadro político conjuntural de Belém e do Pará, analisando duas formas de figuração da Cabanagem: a apropriação feita por Jader Barbalho no governo do estado do Pará e a proposta por Edmilson Rodrigues, à frente da prefeitura de Belém. Ainda que discorde da análise efetuada pelo autor sobre o sentido da Cabanagem na administração de Edmilson Rodrigues, é necessário apontar a sua extensa pesquisa nos jornais da época sobre a disputa dos sentidos do movimento na cidade.
} 
os cabanos é mais real/palpável do que a rememoração da Cabanagem como acontecimento político.

A percepção do pouco enraizamento da Cabanagem na vida e na memória dos homens e mulheres na cidade se apresenta nos marcos da disputa política na fala bastante elaborada e posicionada de Levy Menezes, colaborador da prefeitura no período:

Isso é uma disputa de muito longo prazo. O governo se esforçou no Congresso da Cidade, trabalhou muitos imaginários, aquela ideia de construir uma identidade histórica dos oprimidos e tal. Essa formulação que surgiu dentro da Força [Socialista] no ano de 1998. Mas isso era um processo de longo prazo. No imaginário da população, essa imagem da cabanagem foi muito massacrada. Você vê pela cidade. Você não vê referência alguma. 0 Dulciomar, inclusive, uma das primeiras ações dele, a Aldeia Cabana de Cultura Amazônica, virou Aldeia de Cultura Amazônica. Uma das primeiras coisas que ele fez foi mudar o nome da Aldeia Cabana. [...] Mas a gente não ia conseguir mudar em oito anos um negócio que vinha há 160 anos. A Cabanagem foi apagada da história do Pará. [...] 0 Jader [Barbalho] se apropriou desse discurso da Cabanagem quando foi eleito governador pela primeira vez. Tanto que ele chamou o Niemeyer pra fazer o monumento e tal. Um monumento que o Almir Gabriel abandonou. Os restos mortais dos cabanos, os mendigos fizeram fogueira com os ossos. Jogaram futebol com os crânios. Isso foi apagado da história do Pará. As elites fizeram esse esforço, ao longo de 160 anos, pra apagar isso da história pra que o povo não pudesse olhar pro seu passado e encontrar nele um passado de luta. Era pra que encontrassem um passado de acomodação. Aí, inclusive, têm elementos étnicos muito fortes nessa discussão (Levy Menezes $^{12}$, entrevista concedida à pesquisadora, maio de 2007).

Entretanto, ecoa na percepção de uma moradora e líder comunitária do bairro da Terra Firme como orientação política, ao mesmo tempo em que reconhece seu pouco

\footnotetext{
12 Levy Menezes foi militante do movimento estudantil e popular, trabalhou na SEGEP na coordenação do Congresso da Cidade. A entrevista foi feita em maio de 2007.
} 
conhecimento da revolução cabana, para depois apontar que a Cabanagem não foi assumida pelo conjunto da população como sua identidade ${ }^{13}$ :

Nós temos a história da Cabanagem, que foi uma revolução em que realmente o povo assumiu o poder na cidade. Infelizmente, nós paraenses temos que estudar a cabanagem pra entender a revolução... Eu mesma não conheço muito profundamente. E essa ideia da cidade cabana, do prefeito cabano é porque nós enquanto população realmente tomamos o poder da prefeitura. Nós íamos lá e dizíamos: “Olha, nossa cidade tem que ser assim”. O Congresso da Cidade apontou pra isso. Primeiramente o OP e depois o Congresso da Cidade, que foi uma coisa mais abrangente, que trabalhou não só obras, mas cidadãos. [E você acha que essa ideia da Cabanagem foi assumida pelas pessoas como uma identidade?] Eu acho que... Pra mim, né? Acho que não busquei muito conhecer esse projeto. Eu tava inserida nesse projeto, mas eu não estudei profundamente a questão da Cabanagem. Mas por que a gente se sentia cabana? Justamente por estar participando, poder ter o controle social dessa cidade. Nós tínhamos esse controle. Então, acho que fundamentalmente é essa a questão que a cabanagem traz pra gente: do povo ter direcionado a política a seu favor, ter a certeza da transparência do governo, ter a certeza de que os nossos impostos, que o dinheiro que a gente paga está investido na cidade. Então, a cidade era nossa. É muito triste lembrar que hoje em dia a gente não tem mais isso (Isabel, entrevista concedida à pesquisadora, maio de 2007).

\footnotetext{
${ }^{13}$ Sobre o enraizamento ou não da Cabanagem no imaginário da população, esse resgate e afirmação devem ser tomados como processo; não se trata evidentemente de quantificar o quanto foi bem-sucedido. Essas falas de questionamento da "efetividade" desse processo nos mostram que a disputa política de grande monta que estava em jogo não era um cálculo de soma zero e ratificam a percepção de que essa diretriz política defrontava-se com camadas de opressão e silenciamento. Uma parte do debate proposto por Barbosa (2004) dá conta das disputas cotidianas em torno da cabanagem no governo Edmilson e parece apontar para seu caráter eminentemente estratégico. Ainda que seja possível e necessário reconhecer esse movimento de retomada da Cabanagem como parte de uma estratégia de comunicação social da gestão, perde-se, a meu juízo, a densidade dos debates quando não se constrói o cenário político e a dimensão utópica que o governo municipal procurava afirmar. Sem a consideração da dimensão utópica e seu papel para o conjunto da experiência em Belém, não se pode mensurar essa aposta política, tampouco seus avanços e, menos ainda, suas derrotas.
} 


\section{A aposta em ato: o funcionamento do Congresso da Cidade, algumas questões e seus limites}

O funcionamento do Congresso baseava-se no cruzamento entre plenárias que discutem temas transversais e atividades de base territorial, além de contar com instâncias municipais de discussões setoriais e de direitos humanos que traziam ao debate as questões relativas a mulheres, negros, índios, homossexuais, idosos, crianças e deficientes. Como dissemos anteriormente, o primeiro passo do Congresso eram as reuniões e oficinas preparatórias realizadas segundo a divisão administrativa da cidade, tendo como baliza e proposta de discussão os temas transversais (divulgados em cadernos de teses à população), que serviam de célula para os Congressos Distritais Temáticos e Setoriais e estes, para o Congresso da Cidade.

Após as oficinas e reuniões preparatórias, nos Congressos Distritais Temáticos a população participante, organizada em alguma entidade ou individualmente, discutia o planejamento da cidade a partir dos seguintes temas: urbanístico e ambiental, economia solidária, inclusão social, cidadania cultural, gestão democrática e juventude. Cada um desses temas abarcava mais do que um setor ou esfera da administração: o urbanístico e ambiental compreendia ao de transporte, de saneamento, de meio ambiente, da Agenda 21 e da legislação; o desenvolvimento humano por uma economia solidária englobava ao da economia informal e formal, de turismo e de financiamento; o tema desenvolvimento humano pela inclusão social discutia saúde, educação, assistência e esporte, lazer e, por uma cidadania cultural, envolvia ainda comunicação e cultura; sob o tema gestão democrática, estavam os setores do funcionalismo público, do controle social do serviço público e de informação e, por fim, no tema juventude, discutia-se cultura, esporte, lazer e políticas para o setor.

Ainda na rodada distrital eram realizados congressos setoriais que discutiam os temas específicos de cada setor: mulheres, negros, índios, homossexuais, idosos e deficientes. Eles integravam as discussões de direitos humanos e foram definidos em função do reconhecimento das discriminações e violências específicas sofridas por esses segmentos e/ou grupos e pela necessidade de se desenvolver mecanismos de incorporação de suas questões e problemas no âmbito das políticas públicas municipais. 
Desse processo congressual em âmbito distrital, participavam também as entidades e organizações de classe e da sociedade civil organizada, mas o voto para a eleição do Conselho Distrital era individual, sem a formação de chapa, através da qual se elegiam os delegados em número proporcional à população do distrito. 0 tamanho do Conselho variava em cada distrito em função de sua população, tinha como parâmetro para sua formação a relação de 1 conselheiro para cada 10 mil habitantes. Esse fórum distrital detinha atribuições consultivas e deliberativas de proposição e acompanhamento de políticas públicas voltadas ao seu distrito, embora pudessem propor temas e questões para a cidade como um todo, além de ter sido responsável pelo fomento à introdução dos mecanismos de controle social e seu acompanhamento.

O desenho e a dinâmica do Congresso mudaram ao longo do tempo, especialmente da primeira versão em 2001 para o modelo implantado em 2002.As mudanças de formato e funcionamento era uma prática comum e vinham desde a primeira gestão, com os ajustes e reformulações ano a ano no OP. Tanto lá quanto aqui, essas reformulações eram esperadas e possíveis, uma vez os mecanismos legais de instituição do processo participativo eram flexíveis o suficiente para permiti-las. Aliás, era este o argumento do qual a prefeitura lançava mão para justificar sua opção pela baixa normatização na institucionalização do OP e do Congresso da Cidade.

Entretanto, as mudanças ocorridas entre o primeiro e segundo congressos, nos anos de 2001 e 2002, parecem ter mais a ver com as dificuldades de constituição desse novo formato de participação política. As dificuldades - verbalizadas pelos técnicos e coordenadores do OP contrários à transformação - diziam respeito à pouca inteligibilidade do novo mecanismo com a sua profusão de espaços e dinâmicas, além de sua distância em relação às demandas concretas e cotidianas que emergiam nos bairros e espaços populares. No documento-base do Congresso da Cidade de 2002, assim como em documento de avaliação do processo em 2001, há referências sobre as dificuldades encontradas na instituição desse novo formato de participação. 


\section{Financiamento municipal}

O Congresso da Cidade colocou em discussão a totalidade dos recursos municipais, incluindo aí os gastos com custeio e investimentos ${ }^{14}$. Os recursos de custeio foram discutidos com a população na perspectiva de uma análise e planejamento global da cidade e não apenas da repartição de valores de investimentos entre as demandas setoriais e/ou territoriais. Nesse processo, as situações de constrangimento financeiro enfrentadas pelos municípios sob o governo de Fernando Henrique Cardoso (1995-2002), mantidas posteriormente com o governo de Luis Inácio Lula da Silva (2003-2010), foram importante elemento de discussão nas Assembleias Municipais no sentido de pautar e esclarecer que "o financiamento das demandas sociais não dependem somente do orçamento municipal, pois está ligado, no âmbito nacional, a questões determinadas pela política nacional e estadual" (Rodrigues, 2002b: 99).

A gestão Edmilson Rodrigues se desenvolveu em meio a um cenário de redução da capacidade de investimento das prefeituras brasileiras, decorrente das reformulações introduzidas pelo governo federal na política tributária. Tais reformulações redundaram no aumento de responsabilidades municipais com aumento da participação, financeira inclusive, na garantia de políticas públicas de educação, saúde e assistência social. Esse aumento atribuições, contudo, não foi seguido de aumento dos repasses de recursos para cumprimento dos compromissos advindos dessas novas responsabilidades. Ao contrário, houve significativo corte ou redução de repasse de verbas federais aos municípios, o que fragilizou a sua capacidade de investimento e atendimento das demandas sociais.

Além das medidas federais que atingiram todos os municípios brasileiros, a cidade de Belém teve problemas específicos com o governo do estado do Pará, que cortou o repasse de verbas (para projetos específicos) além dos limites mínimos estabelecidos por lei.

Importa atentar para o fato de que essas "minúcias", muitas vezes distanciadas do cotidiano da cidade, foram objeto de discussão nos fóruns do Congresso da Cidade e objeto específico de análise. A produção de material de comunicação social para informação da população sobre o assunto revela, por um lado, a centralidade que o tema teve por razões óbvias (se não há recursos a serem definidos para e no planejamento de um município, um

\footnotetext{
${ }^{14}$ Esta diretriz, entretanto, é anterior à implantação do Congresso da Cidade e foi efetivada no último ano da primeira gestão petista no processo ainda do OP, em 2000.
} 
mecanismo de participação popular que discute também orçamento perde parte de sua capacidade de diálogo com as reais demandas populares) e, por outro, revela também um processo substantivo de democratização do estado, neste caso, na produção de informação sobre a cidade, num formato acessível (e não rebaixado ou pela metade) articulado a um mecanismo de gestão e controle popular. 0 espraiamento real dessa diretriz pode ser apreendido em vários momentos de fala dos entrevistados:

Nós tivemos uns problemas, mas tem uma resposta pra isso. Quando o Edmilson estava pra assumir Belém, quem estava acima dele, no governo do estado, era o Almir Gabriel, do PSDB. E, evidente, existe aquela disputa. Se ele não faz, ele não quer que o outro faça. Eu participei de vários julgamentos que houve em relação ao ICMS que não foi repassado do governo do Estado pra prefeitura. O Almir Gabriel ficou devendo mais de 600 milhões. Foi um problema muito sério pra gente. A gente tava com aquela ansiedade de levar o problema do bairro pra se fazer, mas estava faltando dinheiro. 0 Edmilson tentou fazer milagre com a pequena arrecadação do município pra poder investir e fazer a vontade do povo. Prestação de conta, todo tempo ele chamava o povo dos distritos pra gente discutir sobre isso. Tinha muita gente que entendia, mas tinha muita gente que saía revoltada. A participação quando houve da comunidade não era só porque era simpatizante do $\mathrm{PT}$, não. (Inês, entrevista concedida à pesquisadora, 08 de dezembro de 2009).

A incidência dessas dificuldades foram sentidas pelos movimentos e impactaram sua organização e sua participação no processo:

Era, era lenta [a execução de obras e demandas votadas] por a gente ser da prefeitura e o governo do estado ser da direita e a gente de esquerda, eles acabavam atrasando muitas obras, não liberavam recursos, tiravam recursos do ICMS e isso prejudicava muito o andamento das coisas. Aí eles [participantes do Congresso ou do setorial] não iam cobrar do governo do estado, eles cobravam da prefeitura. 0 povo acabou ficando desacreditado e não acreditavam, mesmo que tivesse a desculpa mais real e exata do que 
estava acontecendo, eles não acreditavam mais (Cledisson ${ }^{15}$, entrevista concedida à pesquisadora, 22 de maio de 2007).

Além do retardo no repasse do montante de recursos para o município, a política fiscal estadual reduziu os coeficientes de cota-parte do ICMS, ao longo dos anos; ao final de 2004, o índice de participação do ICMS em Belém reduziu-se a 22,17\%, saindo de um índice estável de 39,27\% entre 1994 e 1996, ano da eleição de Edmilson Rodrigues; já no primeiro ano da gestão caiu a 33\% (Galvão, 2004: 81-82). Diante desse quadro, a opção pelo reforço da arrecadação municipal própria (que não dependia de repasses) pareceu a única saída para as situações de constrangimento financeiro que, a julgar pelos números apresentados pela prefeitura de Belém, possibilitou alguma recuperação de sua capacidade de investimento e, assim, do financiamento das obras demandas no Congresso da Cidade e no OP. A possibilidade de discussão da totalidade dos recursos municipais no Congresso da Cidade combinou-se a essa política de reorganização financeira implantada, com vistas à recuperação e aumento da arrecadação municipal, através da reorganização tributária e fiscal da PMB, executada pela Secretaria Municipal de Finanças (Sefin). Tal reforma, posta em prática desde 1997, orientou-se pela tentativa de superar a draconiana repartição de recursos que se estabeleceu entre a União e os Municípios, através de uma política de cobrança da dívida ativa municipal que resultou no aumento da arrecadação através da implantação de cadastro multifinalitário, de reestruturação do ISS, revisão do cadastro e implantação de IPTU progressivo, fim das anistias e cobrança das dívidas ativas, entre outras medidas (Galvão, 2004). Os dados sistematizados nas publicações consultadas sobre a administração apontam para um aumento real da arrecadação e da capacidade de investimento, que podem ser visualizadas, conforme dados da própria Secretaria de Finanças, no gráfico abaixo.

\footnotetext{
${ }^{15}$ Cleidisson é militante do movimento GLBT de Belém, trabalhou na SEGEP no segundo mandato de Edmilson Rodrigues, acompanhando Congresso da Cidade. Esta entrevista foi realizada em 22 de maio de 2007.
} 
Gráfico 1 - Evolução da Receita Própria do Município de Belém, 1996-2003 (valores em milhões de reais/valores correntes)

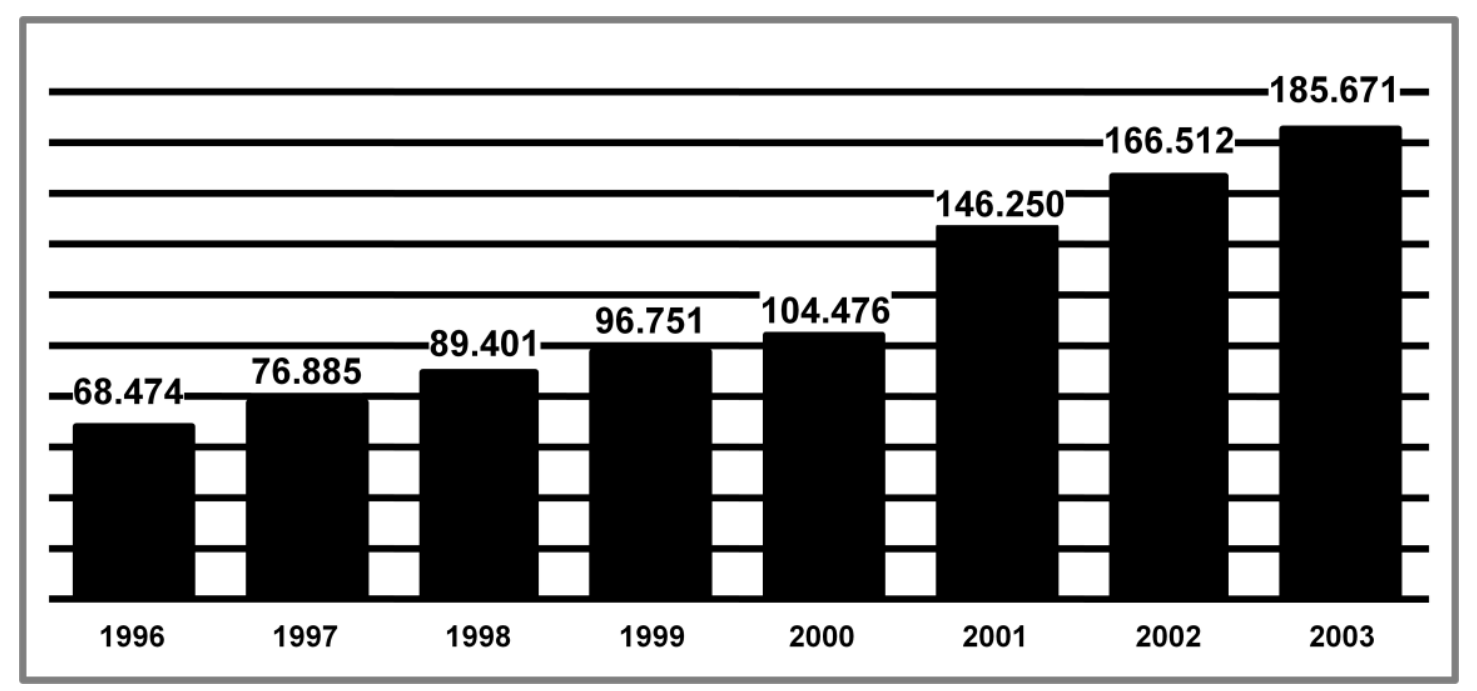

Fonte: Secretaria Municipal de Finanças de Belém

Conjugado ao aumento das receitas próprias, buscaram-se outras fontes de financiamento que incluíam recursos públicos do Banco Nacional de Desenvolvimento Econômico e Social (BNDES), da Caixa Econômica Federal (CEF) e do Orçamento Geral da União e, também, recursos de financiamento e cooperação internacional através do Banco Interamericano de Desenvolvimento (BID), por exemplo. Esses financiamentos foram utilizados em parceria com os recursos municipais especialmente nas chamadas "obras estruturantes" - muitos desses projetos e obras aprovados demandavam mais recursos do que a prefeitura tinha capacidade de aportar. Assim, nesses casos, aprovava-se um pacote de contrapartida para a obra, sendo que o maior montante de recursos viria de outras instâncias. Importantes projetos, como a revitalização da Bacia do Tucunduba, por exemplo, foram demandados e discutidos no Congresso da Cidade e encaminhados, pelo seu porte, para financiamento casado entre prefeitura e governo federal, sendo que a contrapartida municipal era discutida nessas instâncias populares.

\section{Representação política}

No Conselho da Cidade, estavam representados vários setores e grupos sociais, eleitos através de voto direto em urna e por delegação das entidades de classe e de setores organizados nas instâncias anteriores ao Congresso da Cidade, um misto de democracia 
direta e representativa. Eram ao todo cinquenta representantes compondo o Conselho da Cidade, sendo que destes, três eram indicados pelo governo municipal, sem direito a voto. Dos outros quarenta e sete conselheiros, vinte e quatro são eram eleitos diretamente em urna pela população credenciada para o Congresso da Cidade nos congressos distritais; dos representantes eleitos em suas respectivas assembleias de entidade, cinco eram dos Conselhos Municipais, três da representação sindical (CUT, CGT e Força Sindical), três da representação dos empresários e dois do movimento popular comunitário; oito eram eleitos nos Congressos Municipais Setoriais; três pelas representações da juventude; um para cada um dos setoriais de mulheres, deficientes, negros, homossexuais, indígenas; um representante dos servidores públicos, eleito em assembleia pelo seu fórum e, completando o Conselho, um da entidade de representação das ONGs.

O Conselho do Congresso da Cidade tinha como função debater e deliberar sobre as propostas apresentadas e encaminhadas pelas instâncias anteriores do Congresso, ou seja, sobre os temas e propostas discutidos e votados pelos congressos distritais e temáticos que lhes antecederam. Dessa discussão, saía a proposta orçamentária e de planejamento municipal para o exercício do ano seguinte, encaminhado à Câmara Municipal para votação. Era função também do Congresso da Cidade, através do seu Conselho, monitorar as ações de governo e impulsionar a implantação e funcionamento de mecanismos de controle social, tais como condomínios participativos, comissões de fiscalização de obras e serviços e conselhos setoriais.

Um dos acentos principais na organização política do Congresso da Cidade pode ser identificado como o fomento à participação dos setores organizados na mesma proporção ${ }^{16}$ que o fomento à participação dos não organizados. A composição o Conselho e as instâncias do Congresso não baniram nem desmereceram a representação política já constituída na cidade, como podemos ver pela própria configuração do Conselho da Cidade, no qual têm assentos as entidades de classe e fóruns de representação legítimos e reconhecidos.

O OP, quando o Edmilson ganhou a gestão do município de Belém, ele chamou o povo pra questão de ver o que você poderia fazer com o orçamento. E o Congresso foi diferente, ele chamou todos os movimentos

\footnotetext{
${ }^{16}$ A expressão é utilizada em textos sobre o Congresso editados pela Prefeitura Municipal de Belém. Ver Rodrigues e Novaes (2002); Rodrigues, Novaes e Araújo (2002).
} 
pra já pegar o orçamento e investir no que você quer que seja feito. Primeiro houve uma discussão onde foram criadas algumas secretarias porque havia necessidade. Aí depois, sim, chamou todos os segmentos: culturais, sociais, saúde, educação... Todo mundo veio. E o Congresso foi mais abrangente do que o OP porque vieram todos os segmentos. No tempo do Orçamento, não (Inês Barbosa, entrevista concedida à pesquisadora, 08 de dezembro de 2009).

A tentativa de espraiar a participação para setores não reconhecidos classicamente como trabalhadores (para não falar, operários), aponta para uma elaboração sobre a figura do povo e dos trabalhadores. Aqui a concepção de trabalhadores foge da ideia estrita de classe operária, contudo, não se dissipa no amplo conceito de sociedade civil nem apaga as formas de representação social e política já instituídas. Foram privilegiados os espaços de experiência comum da população, não somente os espaços de reivindicação políticopartidária, sindical ou setorial, mas especialmente nos espaços de sociabilidade e de organização comunitária. Tal percepção parece retomar a noção thompsoniana de classe ${ }^{17} \mathrm{e}$ recolocar, por outra via, o debate sobre a formação social e política do Brasil e dos trabalhadores brasileiros.

A participação de setores não organizados ou com baixa vida associativa não é uma característica exclusiva dos processos participativos em Belém, mas aqui ela aparece claramente formulada como um dos eixos de estruturação política de ação. Nessa

\footnotetext{
17 Já clássicos na produção brasileira recente são os textos de Maria Célia Paoli e Eder Sader que trazem a noção de "experiência de classe" ao debate sobre a formação brasileira. Ver especialmente Paoli (1987) e Sader (1988). A experiência de classe como elaboração de uma perda é um dos importantes eixos de análises empreendidos por Paoli a partir da obra do historiador inglês E. P. Thompson. Na sua clássica elaboração sobre a formação dos sujeitos históricos e políticos, Thompson, em diálogo com os textos de Karl Marx, inverte os termos do debate marxista ortodoxo que liam as clivagens de classe a partir de seus lugares econômicos na sociedade e, portanto, exigiam, antes de qualquer experiência coletiva, a existência destes como classe. Thompson (1984) argumenta que a constituição de uma classe é posterior a experiência política coletiva, ou seja, "as classes não existem como entidades separadas, que olha ao seu redor, encontram uma classe inimiga e começam logo a lutar. Pelo contrário, os agentes se encontram em uma sociedade estruturada de modos determinados (crucialmente, mas não exclusivamente, em relações de produção), experimentam a exploração (ou a necessidade de manter o poder sobre os explorados), identificam pontos de interesses antagônicos, começam a lutar por estas questões e no processo de luta, se descobrem como classe, e passam a conhecer este descobrimento como consciência de classe. A classe e a consciência de classe são sempre as últimas, e não as primeiras fases do processo real histórico" (1984:37 [tradução minha]).
} 
formulação defendida pela prefeitura de Belém e introduzida na cidade, estão contados aqueles que têm uma experiência de trabalho, mas que não estão dentro do mercado formal ou mesmo empregados, assim como trazem uma experiência de sociabilidade e de organização que não passa necessariamente pelos mecanismos do sindicalismo nem dos movimentos sociais clássicos, por assim dizer. Parte daqueles que foram chamados a participar da experiência do Congresso da Cidade (e, em certa medida, no momento anterior a ele, através do $\mathrm{OP}$ ), não tinham um núcleo pregresso de filiação política, seja de classe, sindical ou setorial.

Essa articulação entre formas diferentes de organização política, entretanto, não se fez sem tensões e nos coloca questões importantes sobre o debate acerca da relação dos movimentos sociais com os governos e/ou o estado. Apesar de contemplada, como expusemos anteriormente, na organização política do Congresso da Cidade, essa articulação entre a participação direta e as representações políticas instituídas nem sempre foi percebida na mesma proporção, pois, mais de um entrevistado que participou tanto do OP e do Congresso da Cidade, disse perceber neste último, um primado das organizações.

\section{Relação movimentos sociais-Estado}

A criação de uma estrutura participativa com a centralidade política que teve o Congresso necessariamente constitui outra estrutura para lhe dar suporte. Esta é permeável à dinâmica social e , para tanto, parte do processo de participação popular, mas ainda assim é uma estrutura paralela a das organizações sociais e seus fóruns. A experiência participativa nesses espaços desperta para a política setores e pessoas, é um processo formativo e de fomento à organização, apesar destes não constituírem estruturas de movimentos. É inegável, porém, que o incremento das formas de organização popular é um processo alimentado por essa experiência política. Em Belém, o surgimento de novas formas e instâncias de organização e representação de alguns setores, a exemplo dos homossexuais, indígenas não aldeados e afro-religiosos, apontam nesta direção.

Se realmente não fosse esse Congresso, a gente [o movimento GLBT] não estaria tão organizado no estado do Pará como a gente está hoje. E foi o congresso que abriu leques: como é que tu consegues negociar com a secretaria de educação, como é que tu consegues negociar com secretaria 
do transporte. Tudo isso foi o Congresso da Cidade que deu esse norte para os movimentos. (Cleidison, entrevista concedida à pesquisadora, 22 de maio de 2007).

Por outro lado, setores concernidos na disputa percebiam a importância que uma ação como esta, proveniente do governo, tinha sobre a dinâmica organizativa popular e temiam o "aparelhamento" desta. Em outras palavras, temiam que vigorasse um viés de pura estratégia do governo em relação à organização popular, no sentido de lhe garantir apoio político, hiperatrofiando seu peso relativamente a outros entes envolvidos com a administração municipal, como a Câmara ou setores internos à administração de orientação diversa da majoritária.

Por outro lado, essa proximidade entre governo e movimentos sociais foi problematizada por alguns setores que percebiam ali uma dificuldade estrutural do campo de esquerda ou democrático-popular na relação Estado-sociedade:

Essa foi uma das dificuldades iniciais para o próprio movimento e que vai repercutir durante todo governo. Essa reação e adaptação de um conjunto de movimentos sociais a uma dinâmica oriunda do aparelho do Estado. Isso é muito complexo porque mexe com tradições de luta ou de organização, isso cria dinâmicas que não são dinâmicas vivenciadas pelo governo. Claro, como tudo, teve aspectos positivos: os movimentos também acabaram por se rediscutir, pensar, voltar pra si mesmos. Mas não é uma coisa só do governo Edmilson, mas de um modo geral de governos desse campo, de certo alinhamento, de se adequar a essa estratégia oriunda do aparelho do Estado. Na minha avaliação, inclusive, isso é uma das coisas mais difíceis pra sociedade civil, pros movimentos sociais de um modo geral, a relação com o aparelho do Estado. Continua sendo um problema, como dizem muitos autores "nunca vai se resolver". Entretanto é uma relação muito delicada, agora com o governo Lula isso tá muito mais evidente. [...] Então nós vivemos esse problema, mas não é um problema do governo Edmilson, é um problema da esquerda de um modo geral que agora pra mim [é] muito mais difícil, porque [...] antes você fazia esse debate maior, com todos os problemas, mas fazia um debate qualificado sobre essa relação estado e sociedade. Hoje, desapareceu da pauta, poucos são os que discutem isso 
(Guilherme Carvalho, entrevista concedida à pesquisadora, 04 de dezembro de 2009).

A essa preocupação soma-se a necessidade de constituição de um polo popular, não estatal, capaz de contrapor-se à dinâmica do Estado e pautar suas questões desde seu próprio olhar, que sucintamente foi/pode ser expressa assim:

Deixa eu só dizer uma coisinha rápida, que nós sempre defendemos: participemos do Congresso, mas a gente tem que criar uma instância própria de discussão dos movimentos sociais pra intervir no Congresso, certo? Isso nós não conseguimos adesão (Guilherme Carvalho, entrevista concedida à pesquisadora, 04 de dezembro de 2009).

De alguma maneira, essa preocupação aponta as fragilidades/dificuldades do enraizamento da experiência organizativa no seio dos movimentos sociais e populares e anuncia o debate sobre a perenidade desse processo de participação social e da institucionalização (e financiamento) dos mecanismos que lhe sustentam. Por caminhos diferentes e desde pontos de vista posicionados, o que emerge nesta discussão é o questionamento sobre o papel dos movimentos sociais em governos populares e/ou de esquerda e sua relação com o aparelho de estado. A linha de tensão aparece com mais força no debate sobre a potência de atração do estado sobre os movimentos sociais.

Os números sistematizados pela SEGEP da participação no Congresso desde $2001^{18}$ mostram um crescente de mobilização para participação em suas instâncias (plenárias, oficinas preparatórias e os congressos distritais e municipais) que, inclusive, extrapolou o âmbito municipal através da participação de moradores dos municípios de Ananindeua e Marituba.

\footnotetext{
18 Os números de participação usados aqui foram sistematizados pela Prefeitura de Belém, especificamente pela Segep, responsável pelo funcionamento do Congresso da Cidade, e estão disponíveis nas publicações citadas na bibliografia. Não foi possível manipular os dados primários sobre o Congresso ou mesmo o OP.
} 
Tabela 1 - Evolução da participação da população nas instâncias do Orçamento Participativo e do Congresso da Cidade (1997-2004)

\begin{tabular}{l|llll|llll|}
\hline \multicolumn{4}{|c}{ Orçamento Participativo } & \multicolumn{4}{c}{ Congresso da Cidade } \\
\hline Ano & 1997 & 1998 & 1999 & 2000 & 2001 & 2002 & 2003 & 2004 \\
Participantes & 15.000 & 25.000 & 50.000 & 140.000 & 30.004 & 95.000 & 225.739 & 261.053 \\
\hline
\end{tabular}

Fonte: SEGEP, PMB.

Fica claro, a partir desses dados sistematizados pela prefeitura de Belém, ao longo dos oito anos daquela gestão, um aumento substantivo ${ }^{19}$ da participação popular nos fóruns e instâncias propostas - o que demonstra ou aponta o efetivo espraiamento da participação política para o conjunto da população.

Desdobrando esses números gerais de participação, alguns elementos importantes surgem e indicam que a experiência política dos setores populares que afluíram para o Congresso da Cidade parece ter relação com os assuntos e debates travados em suas instâncias. Na rodada municipal, a maior participação se deu nos congressos setoriais de mulheres e deficientes e nos Congressos Municipais Temáticos, a maior participação se dá no eixo Inclusão social. Já nos Congressos Distritais Temáticos, os eixos inclusão social e juventude, somados, são responsáveis por 50\% da participação. Seguindo a mesma tendência de participação, de publicização e debate de questões e temas (que revelam o grau de precariedade da vida que foi colocada em pauta por este mecanismo de participação popular) aparecem os números de $47 \%$ de participação no setorial de mulheres e 32\% de portadores de deficiência no Congresso municipal de direitos humanos.

No eixo inclusão social, estavam previstas discussões sobre temas que não se encerram nos "programas compensatórios", para usar a expressão de Roberto Schwarz, ou no que a literatura recente chama de "programas sociais". Nesse eixo, como já dissemos anteriormente, eram computadas as políticas públicas de educação, saúde e assistência social (ainda que seja discutível até que ponto assistência social está dentro do horizonte de universalidade pretendido e suposto nos dois anteriores), esporte e lazer. Nessa perspectiva, os programas e os recursos concernidos no eixo inclusão social misturavam-se

\footnotetext{
19 Há que se notar a queda significativa em 2001, primeiro ano do Congresso da Cidade ao nível do segundo ano do OP, e depois disto o crescimento acentuado nos anos posteriores.
} 
e misturaram o debate público pelos direitos sociais e, em certa medida, reorganizaram a cena no momento em que colocavam os programas compensatórios na órbita da política. Além de indicarem uma disputa em torno dos significados e sentidos da "inclusão social".

As obras "atrasadas" previstas pelo OP continuaram no plano de obras que a prefeitura apresentava anualmente para o debate no Congresso da Cidade. Além disto, as demandas por obras localizadas seguiram em debate nas instâncias do Congresso, mas agora articuladas aos projetos estruturais. Ainda que articulada, há que se notar que a continuidade do aparecimento (e também da discussão sobre elas) dessas demandas indica justamente o caráter de urgência que lhes caracteriza e com o qual um projeto de gestão partilhada e planejamento participativo terá necessariamente que se haver. É preciso considerar que o atendimento de algumas demandas corresponde à vitória de lutas históricas por reconhecimento da existência de parcelas imensas da população que na cidade habitam áreas precárias; "sobras" de espaços, desprovidas de infraestrutura. Essa condição objetiva de impossibilidade de acesso à cidade na sua plenitude revela o modo autoritário e violento através do qual essas populações foram tratadas. Se é verdade que pertencimento e existência política são mais do que uma cesta de serviços urbanos, não há como negar que, da impossibilidade de acesso aos mínimos vitais, transparece (e reafirmase material e simbolicamente) o lugar rebaixado - em suas múltiplas e intrincadas dimensões econômica, política, territorial, cultural, social - imposto a esses grupos.

Indícios dessas tensões podem ser percebidos nas falas dos entrevistados, especialmente daqueles que participaram do Congresso da Cidade, apontaram demandas, construíram pautas e políticas públicas e, entretanto, quando indagados (e defrontados) sobre as conquistas do processo participativo apontam menos para a realização "objetiva" e quantitativa dessas demandas do que mais firmemente para a dimensão de afirmação política do seu grupo e constituição de um lugar de fala e debate público.

Nessa questão da descentralização de governo com a participação do povo nas decisões, em algumas coisas, lógico que na execução tinha mais dificuldade por que financeiramente a gente não tinha orçamento, né. [...] Um dos grandes problemas a gente não poder não ter orçamento o suficiente pra executar as demandas, que é importante porque tal comunidade ela reúne, ela discute, ela vai e ia. [...] Nossos congressos eram 
de 800 , de 1 mil pessoas participavam e a gente conseguia mobilizar a sociedade daquele distrito pra participar do processo das decisões. Congresso de juventude, congresso do saneamento, congresso de educação, vários congressos, alguns congressos que eram mais e outros menos participativo, mas a maioria tinha uma grande participação da comunidade. E era interessante que era mobilizado pela comunidade, mas também tinha comunidade geral que ia pro Congresso. [...] Todos os trabalhos de controle social que nós tivemos pra fazer os conselhos pro governo do Edmilson, o governo do PT, foram estímulo à questão da participação popular do controle social. Foi muito estimulado a criação dos conselhos de controle, dos conselhos de direitos, então isso foi muito importante nesse governo. (Domingas de Paula ${ }^{20}, 07$ de dezembro de 2009).

Para além destes números e das tensões que envolvem a administração dos recursos escassos numa cidade com dívidas sociais imensas e históricas, não é menor a importância que uma das principais entidades de representação dos indígenas "urbanos" moradores da região metropolitana de Belém constituiu-se a partir das discussões no Congresso da Cidade, através dos congressos dos índios, que aconteceram regularmente desde 2001. Os indígenas organizados na Associação dos Indígenas da Região Metropolitana de Belém (AIAMB) têm representação no Conselho Municipal de Direitos Humanos, desde 2003, e no Fórum de Mulheres da Amazônia Paraense, desde 2005 (Almeida, 2005). Desta perspectiva, a tensão recrudesce.

Eles [o governo] que descobriram [e chamaram para participar do Congresso]. Nós éramos conhecidos porque na marcha dos 500 anos, o PT era aliado nosso. Então, nesta época o Edmilson Rodrigues que foi prefeito era do PT, e hoje ele está no Psol, se desmembrou do PT. Então, era uma coisa muito útil para nós. Todo mundo participava, todo mundo, união. Você imagine quando o Edmilson foi prefeito, ele só governou com movimentos populares. Essa coisa que foi muito importante pro governo do Edmilson porque ele não dependia da aprovação dos vereadores. Com isto, os

\footnotetext{
20 Domingas de Paula é educadora e militante do movimento popular em Belém, foi administradora do Distrito do Bengui entre 2001 e 2004, atualmente é da executiva do Fórum da Mulher Paraense, coordenadora do Grupo de Mulheres Brasileiras e é da executiva do Fórum de Mulheres da Amazônia Pará. A entrevista foi feita em 7 de dezembro de 2009.
} 
vereadores até ficaram com raiva dele. Porque todos os projetos era nós que criávamos. Tinha os técnicos pra analisar e aí ia pra Câmara só mesmo só pra passar por lá. E aí a gente ia todo dia pra lá pra Câmara e os vereadores tinha que aprovar. Então, foi muito importante isto, orçamento participativo na administração do Edmilson foi muito importante isso [...] É... não conseguimos nada porque era muito difícil. [...] Porque ele governou desta maneira, é assim uma briga com Almir Gabriel. Tanto que Edmilson foi criar um projeto e ele ia embargava a obra. Mas como a força da sociedade civil organizada, da população a gente quebrava isto. Era uma política muito difícil. Mas ele governou a prefeitura de Belém. [...] Melhorou [para os indígenas nesta época] foi os conhecimentos junto da sociedade. E isto até hoje a gente tem na memória (Emílio Kabá, entrevista concedida à pesquisadora, 04 de agosto de 2009).

Estas e outras falas dão conta desta tensão que não era apenas uma percepção desde os movimentos sociais, ela estava presente no corpo político orgânico do governo e, me parece, estava já vislumbrada e anunciada como seu próprio limite na proposta política que se construiu em Belém.

Essa crise, vou chamar assim, do financiamento do ente político município, eu acho que esse é um elemento fundamental que limita e tensiona a resistência de um processo de participação popular porque vai levantar um conjunto de demandas que geralmente correspondem a uma dívida social acumulada em décadas, em longos períodos, e você tem quatro anos ou oitos anos no caso de reeleição pra tentar resolver. Claro que um governo popular implica, pra ser popular mesmo, em uma decisão que paga o preço orçamentário, financeiro de respaldar o processo de participação popular. Então, você poderia realizar obra de maior envergadura na cidade, obras de visibilidade, mas ao fazer isso você não estaria... ou fazer apenas isso poderia até te dar um substrato eleitoral mais direto, você estaria optando por não atender aquela cesta muito variada de demandas, de pequenas obras, de obra localizada, de obras que não aparecem porque são muito internalizadas na periferia. Então, é essa necessidade de mediar o atendimento das demandas concretas, portanto um investimento e uma 
priorização de recursos pra essas demandas sociais, ao mesmo tempo em que você não limita a isso. Fazer um processo de formação continuada, de formação política, de politização social pra que a população possa entender que dentro dos limites da gestão de um município são alterar as linhas fundamentais da economia nacional e a própria relação do país com o contexto da economia global etc. e você não consegue resolver a totalidade daquelas demandas. Só que tem um detalhe, quer dizer, a população ia pro OP ou ia pro Congresso da Cidade, e se mobilizava centenas e milhares de pessoas em cada assembleia acreditando que aquelas demandas hierarquizadas ali naquelas assembleias iam ser cumpridas. Se você não cumpre, se você não cumpre absolutamente o que foi decido ou pelo menos não cumpre em parte, no ano seguinte você não tem mais, aquela mesma pessoa não vai se mobilizar de novo. A existência de obras concretas, eu digo que muitas vezes obras pequenas, obras locais, isso era o combustível que fazia com que aquela parcela da população pudesse inclusive continuar participando e ao participar de um congresso, de um seminário, de um colóquio, tomar contato com uma variação política critica e se armar de instrumentais mais críticos de análise da realidade. Então, nesse sentido, o Congresso da Cidade mais do que a experiência inicial do OP, se prestava a essa visão mais global, mais totalizante da cidade, das questões políticas, sem poder abrir mão de ser também um espaço pra sistematização de demandas sociais locais e sua concretização (Aldenor Araújo Jr., entrevista concedida à pesquisadora, 02 de dezembro de 2009).

Novamente, o projeto, a aposta política posta em movimento no Congresso da Cidade e suas conquistas revelam os limites de um projeto de transformação social nos contornos de uma ação localizada.

Por melhor que pudesse ter sido ou que tenha sido o resultado da utilização desse instrumento de poder, no ponto de visto da construção de um mundo diferente, de uma vida diferente, a existência da consciência por parte do governo da limitação a esse instrumento. Então, ninguém governou e ninguém entrou no governo achando que o governo era o fim. E o trabalho que foi realizado de participação popular tentou ser um instrumento de 
conscientização disso, que o governo é uma parte, é um elemento, é um instrumento, pode servir ou prestar muito serviço. E abrindo sempre essa possibilidade: a organização do povo. [...] Nós somos uma parcela do poder que pode ajudar a instrumentalizar isso ou aquilo, pode melhorar a vida, pode criar uma perspectiva de uma vida melhor. Cada resultado, digamos assim, do Congresso da Cidade e a viabilização através das políticas públicas das demandas, elas eram sempre entremeadas dessa reflexão (Marinor Brito, entrevista concedida à pesquisadora, 31 de julho de 2009).

De alguma maneira, além do "combustível das pequenas obras" como o chamariz para uma discussão que, ao se fazer, almeje romper os limites de uma ação enclausurada nas necessidades e se politizar dessa forma, o que ainda parece brilhar é a utopia, a disposição para enfrentar a "roda da fortuna", para usar uma expressão de Maquiavel.

No livro em que discute os sentidos da democracia contra o Estado, Miguel Abensour condensa o que poderia ser em potência a tentativa dessa elaboração da política, e que me parece ser uma chave pertinente para interrogar a experiência participativa em Belém (mas não só esta).

Democracia contra o Estado pode significar para nós uma sensibilidade diante dessa forma estranha de experiência política que, realizando-se no tempo e "na prática efetiva" das instituições políticas - uma maneira de ser do político em termos de J. Rancière - em que se manifesta a constituição da vontade coletiva do povo - um ser político - na medida em que sua unidade não prejudica a condição de pluralidade - e que, em um mesmo movimento, para preservar suas instituições, a instituição democrática do social não cessa de erguer-se contra o Estado, afirmando in actu a possibilidade de suprimir a divisão entre governantes e governados, ou de reduzir quase a zero, de inventar um espaço público e um espaço político, sob o signo da isonomia. Em resumo, uma transformação do poder, em condições de agir em concerto, ou se preferir, uma passagem do poder sobre os homens, ao 
poder com os homens e entre os homens, o entre sendo o lugar em que se ganha a possibilidade de um mundo comum (1998: 127 [grifos do autor]) ${ }^{21}$

A elaboração proposta por Abensour nos indica uma possibilidade da política e da democracia, nos termos que ele está pontuando na sua leitura de Marx, como um movimento tenso de instituição de "um espaço conflituoso, de um espaço contra, de uma cena agonística na qual se confrontam as duas lógicas, se desenvolve uma luta, sem trégua, entre a autonomização do Estado, enquanto forma, e a vida do povo, enquanto ação." (Abensour, 1998: 125). E neste sentido, corrobora a percepção da política menos como um processo de instituição de um estado renovado e purificado, preenchido com os conteúdos e necessidades populares, ou mesmo o desaparecimento do Estado, mas um "espaço de conflituoso" (Abensour, 1998: 124), de confronto entre interesses diversos assim como um espaço de luta contra a petrificação da forma Estado e da democracia do estado de direito.

Com essas lentes, é possível dizer que a aposta política que se constituiu em Belém é, desde seu nascedouro, atravessada por uma tensão (e um limite): seu núcleo gerador é o governo, a aposta numa experiência democrática é parte constitutiva de uma política de governo e, mais, ancorada no Estado - ainda que induza uma ação de longo prazo contra o Estado, nesses termos que Abensour expõe. De alguma maneira, é uma aposta que só se realiza plenamente se romper (ou modificar profundamente) as estruturas estatais (assim como a ordem econômica e social) que lhe dão suporte.

\section{Silenciamento}

Se a disposição de enfrentamento do "safado da vida" encontrou no Congresso um espaço importante de construção coletiva na multiplicidade de representações e setores populares, fora dos seus limites, encontrou um silêncio, ou melhor, um silenciamento por parte das elites políticas e econômicas paraenses. Dois movimentos se combinaram nesse silêncio e dizem muito da relação das disputas em torno das concepções políticas de cidade naquele momento. 0 primeiro deles é a pouca participação dos segmentos empresariais e

\footnotetext{
${ }^{21}$ Abensour (1998) discute o legado de Karl Marx e o estatuto da política em sua obra, enfrentando temas centrais para discussão da modernidade: a ação política, o Estado, a liberdade e conceitua a "nova democracia" justamente como uma possibilidade de experiência política que se faz não dentro do aparelho estatal mas, sobretudo, dirigindo-se contra ele.
} 
de comerciantes nas instâncias do Congresso. A construção do Congresso foi, como já dissemos antes, precedida por atividades e debates durante os anos de 1998 até 2000, antes de seu lançamento oficial em novembro de 2001. Além desses debates temáticos, a prefeitura organizou visitas aos vários setores que em sua proposta de composição do Conselho teriam assento e a outros setores como o de comunicação que tinham incidência sobre a dinâmica da cidade. Algumas visitas específicas às entidades de representação empresarial foram feitas (e noticiadas, inclusive, nos jornais locais) no sentido de sensibilizá-los sobre a importância de sua participação naquelas instâncias que estavam se montando.

Numa reportagem grande em $O$ Liberal, a jornalista Hanny Amoras entrevista o prefeito Edmilson Rodrigues sobre o Congresso da Cidade e sobre as visitas aos grupos empresariais.

As Organizações Romulo Maiorana estão entre as empresas convidadas para participar do congresso. 0 convite foi feito na terça-feira, 24, em visita que o prefeito fez ao vice-presidente das ORM, jornalista Romulo Maiorana Júnior.

Por que o convite às ORM?

[Edmilson Rodrigues] Pela importância que tem para o Estado do Pará e para a cidade de Belém um órgão como as Organizações Romulo Maiorana, no sentido de participar de um processo de planejamento estratégico da cidade, que deverá envolver todos os segmentos da sociedade, todos os setores, todos os atores sociais que pretendem contribuir com o debate sobre o futuro de Belém. A esse processo todos estamos chamando de "Congresso da Cidade", que pretende, ao reunir os vários segmentos, estabelecer um cronograma permanente de ação (O Liberal, 29 de novembro de 1998).

É importante dizer que, com o mesmo intuito, os jornais locais foram visitados e todos noticiaram a visita. Nesse mesmo período, foram veiculadas notícias sobre os debates que ocorreram em Belém acerca de gestão urbana, na qual tiveram presentes prefeitos de cidades do país. O lançamento do Congresso da Cidade ao final desse ciclo debates foi noticiado pelos jornais Diário do Pará e A Província do Pará com algumas matérias, mas 
teve repercussão econômica em $O$ Liberal. Digno de nota, no entanto, é a coluna de Meirevaldo Paiva, articulista do jornal, que em sua coluna semanal escreve um texto, após a o lançamento do Congresso da Cidade sob o título “Qual cidade? Qual futuro?” que se não chega a tecer algum elogio ao Congresso, saúda a boa iniciativa de partilha de poder, sublinhando que Belém não é a primeira a cidade a fazer isto mundo a fora.

Essa série de visitas e conversas de convencimento parece ter surtido pouco efeito, dado que os setores empresariais pouco disputaram os destinos de Belém nos espaços do Congresso da Cidade. Contudo, parece indicar a importância estratégica que o setor de comunicação detinha na cidade e apontar ainda para a percepção da comunicação como um espaço de disputa política de grande envergadura tanto por participantes do Congresso vindo dos movimentos sociais quanto por parte da administração.

A importância dos meios de comunicação revela o poder político muitas e tantas vezes subsumido numa suposta postura jornalística como sinônimo de isenção. Por trás das coberturas e noticiamento das atividades, o que esteve em pauta em Belém neste período foi uma verdadeira disputa política, percebida como elemento fundamental na construção do campo de conflitos naquele momento, como nesta fala de uma militante do movimento das rádios comunitárias:

Foi se enraizando [a experiência de participação popular], mas hoje eu percebo que as pessoas, por mais que queiram se manifestar, elas não encontram eco pra isso. Aí parece que isso está se perdendo porque muitas vezes a gente questiona o que está acontecendo porque a gente não participa mais, não reivindica mais os nossos direitos... Porque eu participava do governo, não é? Será que a gente não conseguiu sensibilizar a população para que ela continuasse sendo ator dessa sociedade, buscando esses direitos? Mas aí a gente começa a perceber que tem uma força muito grande contra isso tudo, que é a mídia aqui no Pará, que é muito forte. A gente tem grupos de poder aqui na cidade que se a população não participar é melhor. Ninguém questiona, deixa como está e eles trabalham do jeito que eles querem (Isabel, entrevista concedida à pesquisadora, maio de 2007). 
Além da importância estratégica nos marcos de uma visão de conjunto da centralidade dos meios de comunicação nas disputas políticas, a disputa cotidiana também foi sentida imediatamente pelo recém-eleito governo municipal perdurando os dois mandatos e combinava elementos de desacordo político com interesses materiais.

Não demorou nem quatro semanas, cinco semanas, pra se expressar também uma campanha midiática muito forte contra o nosso governo, no caso a campanha liderada pelo grupo [de O] Liberal, que cobrava o pagamento de uma conta milionária de empenhos de publicidade, relativos a serviços de propaganda institucional que teriam sido efetivados e não pagos pelo governo anterior. Então a campanha que $O$ Liberal deflagra contra a administração do Edmilson na época não teve apenas um móvel ideológico. Quer dizer, isso tava presente. [...] A elite empresarial, a elite midiática, digamos assim, não engoliu de bom grado aquela surpresa, mas havia um sentido de cobrança de fatura, de chantagem explicita. [...] Esse cerco midiático que a prefeitura sofreu logo no seu nascedouro, não deixou de ser uma característica que nos acompanhou os oito anos. Mas com momentos de maior tensão ou de uma certa distensão, uma paz armada, vamos dizer assim, em vários momentos com picos de agressividade. 0 governo começa num momento de muita agressividade (Aldenor Araújo Jr, entrevista concedida à pesquisadora, 02 de dezembro de 2009).

Se é possível identificar momentos de maior tensão e de debate público em torno das ações e propostas, é preciso também estar atento à disputa de baixa intensidade, chamemos assim, mas que se faz cotidianamente com o noticiamento (ou não) das atividades de participação popular. Se a tensão é a face visível dessa disputa, o não comparecimento ou ainda a forma como é retratado nos meios de comunicação o Congresso da Cidade (leia-se aqui, as formas de participação popular na gestão da cidade), revela a visão que os empresários da comunicação tinham sobre esse movimento de constituição de um espaço de debates públicos sobre a cidade e de seus sujeitos.

É curioso notar que no período de 2001 a 2004, com o Congresso já instalado como forma de gestão pública na cidade, as notícias que são veiculadas nos jornais continuam a cobrir apenas os grandes eventos do Congresso: os momentos das grandes plenárias ou de 
eventos culturais e de lazer a elas vinculados. As notícias diretamente relacionadas ao Congresso da Cidade apareciam nos jornais em poucos editorais ou notícias opinativas. Percorrendo o conjunto de notícias reunidas pela Biblioteca da Segep, é possível notar que se cobria preferencialmente/majoritariamente os grandes eventos ao longo do ano e, especialmente, atividades de alguns setoriais que fizeram parte dos congressos temáticos como o de crianças, homossexuais e indígenas. Essa cobertura em certa medida está em sintonia com a forma como um de seus editores percebe a relação entre $O$ Liberal e essa administração.

Porque o Edmilson pertence a uma corrente política ainda muito ligada ao trotskismo e aquela coisa mais revolucionária, sabe? Eu lembro que cheguei a fazer reportagens com ele e ele trazia gente de associações revolucionárias, do México, de Chiapas, ele é muito ligado a isto. [O Liberal] tinha uma posição contrária, mas a gente cobria, né? A gente não apoiava, mas a gente cobria. A gente vive numa cidade que prefeitura e governo... não é uma cidade altamente industrializada, é uma cidade com uma circulação menor de recursos, então o poder público acaba sendo muito importante na condução da vida da cidade. Você vê que eventos culturais, obras... tudo que mexe com a vida das cidades, o percentual que cabe ao poder público é muito maior do que o que cabe ao setor privado. Então, se você deixar de cobrir [...] não vai noticiar (Lázaro Moraes $^{22}$, entrevista concedida à pesquisadora, 23 de agosto de 2011).

Na entrevista citada, é curioso, tanto quanto revelador, notar que a referência a eventos políticos com os quais $O$ Liberal não concordava dava pistas justamente de um momento bastante noticiado pelo jornal com a referência a Chiapas e aos "revolucionários" do México, os zapatistas, que não era exatamente o Congresso da Cidade, mas que estava justamente no conjunto de questões que o governo procurava articular aos mecanismos participativos em Belém através da afirmação de referências de luta e resistências populares irmanadas ao seu projeto político. O Fórum Pan-Amazônico mereceu destaque na

\footnotetext{
22 Lázaro Moraes é editor executivo do jornal diário $O$ Liberal, pertencente ao grupo ORM. Na época da gestão de Edmilson Rodrigues era editor de economia e política. A entrevista foi realizada na redação do jornal, no dia 23 de agosto de 2011.
} 
cobertura no mês de janeiro de 2003, das quatorze referências ao Congresso da Cidade catalogadas pela Segep, nove são relacionadas ao Pan-Amazônico e o tem como mote da notícia. O Fórum, que contou com apoio político do governo municipal, coincidiu com encerramento do II Congresso da Cidade, mas este teve visibilidade reduzida. Em contraste, a capa do jornal $O$ Liberal, de 20/01/2003, traz uma foto de um indígena sem nome ou etnia com uma legenda que diz: "Índio no Fórum Pan-Amazônico: comunidades reclamaram da falta de liberdade para atravessar fronteiras".

É importante sublinhar que as notícias diretamente relacionadas ao Congresso da Cidade apareciam nos jornais em poucos editorais ou notícias opinativas. Percorrendo o conjunto de notícias reunidas pela Biblioteca da SEGEP é possível notar que se cobria preferencialmente e majoritariamente os grandes eventos ao longo do ano e especialmente, atividades de alguns setoriais que fizeram parte dos congressos temáticos como de crianças, homossexuais e indígenas.

Este falar/silenciar sobre o Congresso da Cidade esteve acompanhado, como já pontuamos, da não participação em seus fóruns, decisão posicionada politicamente que deixava transparecer o desacordo desses setores com a orientação da administração e do processo participativo ali instaurado.

Olha, sinceramente não foi [tranquila a relação entre empresários e governo municipal]. Assim, é que realmente há aquele ranço do empresário contra o pessoal da esquerda. E o governo é um governo de esquerda realmente. E poucos empresários participavam do governo da cidade. Eu era um dos poucos que era ligado à entidade de classe e participava. Outras entidades não participavam. Eu ia aos debates, dava sugestões, opiniões e eu gostava muito, né! Gostava mesmo, porque eu sou cearense, vim de uma cidade pobre, e eu sei que o pobre nunca tem vez nem voz. 0 pobre simples está lá, sempre precisa engolir goela abaixo, não é verdade? E eu dou muito valor a isso, porque o Congresso era uma democracia, uma democracia aberta ao debate. [...] 0 prefeito apoiava totalmente essa participação política dos negros, dos índios, dos gays. Os gays ganharam um dedo de voz nesse tempo. [...] Quando você vê que o Congresso era composto da maneira dos pobres, negros, índios, gays e aí já o rico falava: "isso daí é negócio de comunista". Até me chamavam de petista, de comunista, porque eu ia lá e 
dava recado assim-assado. E tinham trinta e quatro diretores e eu falava no microfone, falava grosso, alto e dizia, elogiando o Congresso. E os caras já estavam me chamando de petista, de comunista, de esquerdista (Omar Fernandes ${ }^{23}$, entrevista concedida à pesquisadora, 28 de julho de 2009).

Porém essas diferenças políticas e de orientação estavam casadas também com as diferenças de ação no campo dos interesses. Entre o setor dos empresários e a gestão da prefeitura, havia níveis de disputas. Há o segmento de comerciantes e pequenos empresários, mais articulados às dinâmicas local e regional, que frequentam menos os circuitos nacionais e internacionais do capital, cuja resistência à gestão de Edmilson Rodrigues, ainda que tivesse os componentes de costume, não parece se pautar por uma visão sistêmica crítica e divergente da concepção expressa pela gestão municipal. Um caso emblemático foi o da suposta permissividade da prefeitura com os camelôs, vendedores ambulantes e todo um conjunto de relações que se constitui a partir da informalidade do mercado de rua.

O governo do Edmilson era voltado para o pobre e o empresário não entendia isso, achavam que as soluções da prefeitura teriam que partir para a classe média, para o centro da cidade que é cheio de camelôs. Muitos problemas no centro da cidade, isso daí o governo não deu jeito, que até o atual não deu jeito, são vários governos que não deram jeito, que é um problema social muito grande. Tem mais de 10 mil ambulantes no centro... Ambulantes, camelôs, as ruas são tomadas. Se você for no centrão, você vai ver que nem entra carro, é só camelô, as banquinhas. Mas aí é questão de sobrevivência, né! E aí o Edmilson não era benquisto. Ele olhava mais para a periferia, para os problemas sociais da classe baixa. E aí, entraram em choque (Omar Fernandes, entrevista concedida à pesquisadora, 28 de julho de 2009).

\footnotetext{
${ }^{23}$ Omar Fernandes é representante comercial e como presidente da Associação Comercial do Pará participou do Congresso da Cidade como um dos representantes do segmento de empresários.
} 
Cumpre ainda dizer, que esses setores médios dos empresários e comerciantes, em certa medida, participaram de fóruns regionais e de debates específicos que lhes tocavam imediatamente.

Assim, é possível dizer que a disputa que se deu em Belém no período em questão, e que teve no Congresso da Cidade uma face de expressão, tem diversas frentes. Uma destas parece ser a do enfrentamento com um projeto político antagônico, cuja voz mais clara parece ser a dos grandes empresários (englobando aqui os dos meios de comunicação) e das elites políticas paraenses. Nesse campo de conflitos, o tom da disputa e os termos do embate, como tentamos demonstrar, estão num diapasão da disputa política-ideológica de grande monta, que estrutura o conflito para além das conjunturas municipais. Trata-se de uma discordância sistêmica com o projeto materializado nas formas de participação popular que se fomentou, uma vez que elas encarnavam uma crítica profunda às estruturas de exploração e dominação vividas pelos pobres e trabalhadores. Se, de fato, os oponentes que encarnavam projetos antagônicos propriamente ditos não foram aos fóruns de participação - tanto ao OP quanto ao Congresso -, é preciso reconhecer alguns segmentos desses grupos locais que faziam oposição à gestão municipal fizeram incursões nesses espaços.

Enxergar esta quase participação das elites paraenses no Congresso da Cidade e, portanto, sua relação com tudo aquilo posto em movimento nesse processo nos trás a tona as figurações é um processo - mais um - de silenciamento operado naquele momento não apenas como violência física, mas também como não reconhecimentos dos sujeitos que para lá foram como interlocutores. Trata-se de reiterar a impossibilidade de fala às classes populares, a recusa do reconhecimento da igualdade contingente sobre a qual se assenta toda a vida democrática.

Nesse não reconhecimento destes outros como sujeitos políticos, isto é, como iguais, importa pouco se o que se discute é o nome de uma avenida que deixa de ser chamada com os nomes dos generais presidentes e passam a ter o nome de "guerrilheiros comunistas" ou as diretrizes da política de atendimento de saúde, afinal, concordando com Rancière:

Nenhuma coisa é em si política, pois a política só existe por um princípio que não lhe é próprio, a igualdade. 0 estatuto desse "princípio" deve ser precisado. A igualdade não é um dado que a política aplica, uma essência 
que a lei encarna nem um objetivo que ela se propõe atingir. É apenas uma pressuposição que deve ser discernida nas práticas que apõem em uso (Rancière, 1996: 45).

Para os povos e comunidades de Belém, o que está em disputa nesse processo - e por isto a experiência do Congresso da Cidade parece tão importante ainda que com todos os seus limites, contradições e descontinuidade - é a possibilidade de existirem politicamente, enraizados na sua história. Mulheres e homens, jovens, velhos, tembés, gays, mundurukus, ribeirinhos, travestis, negros, pais de santos, militantes da saúde, sindicalistas, caiapós, militantes de moradia, comunicadores, professores, vendedores de feira... enfim, um conjunto de sujeitos toparam discutir seus destinos em comum, fazendo disto mais do que uma soma de diferenças. E, nesse caminho, construíram uma cena pública na qual se diziam iguais - no sentido preciso de Rancière -, contrariando seu passado de exploração e esquecimento, reivindicando a reparação de um dano, a desigualdade cotidianamente experimentada.

\section{O que Belém fala sobre o Brasil}

As diferenças do Congresso da Cidade em relação a outros processos de participação não são uma questão meramente formal: a estrutura do Congresso da Cidade, seu funcionamento, os temas ali tratados e os sujeitos concernidos nesta disputa são, ao mesmo tempo, forma e conteúdo. Essa estrutura (a relação entre forma e conteúdo) nos permite ver aquilo que continuou nublado na consideração da formação brasileira e permite tomar as nossas "especificidades" como elementos constitutivos e não com distorções a serem superadas.

A experiência de Belém nos abre uma perspectiva a partir da qual interrogar a participação popular no Brasil: considerá-la coma experiência que excede os limites da gestão das precariedades justamente porque introduziu e incorporou na gestão das cidades a dimensão utópica, através da participação e do olhar daqueles que historicamente estiveram à margem da vida pública. Espelham-se nos seus pressupostos e no seu cotidiano 
as esperanças de um projeto de transformação social que, reconhecendo os limites da ação municipal, não se abstém do debate e da disputa política estratégica. Disputa e utopias que se constituem a partir da memória de luta dos oprimidos, dos cabanos e dos povos da floresta como sujeitos da forja de um futuro para esta cidade, e quiçá, para o país.

Os temas e questões presentes na vida política de Belém apontam não somente para sua especificidade em relação ao Brasil e à construção de mecanismos de participação popular e de ampliação da cidadania. Esta experiência em Belém fala sobre o processo recente de constituição da vida política brasileira, justamente através e em função daquilo que parece, à primeira vista, afastá-la da média das experiências brasileiras.

Dito de outra maneira, parte da tradição do pensamento brasileiro entendeu São Paulo como síntese (imperfeita, é verdade) e como indutor da modernização brasileira. As clivagens arcaico-moderno e urbano-rural compreenderam as dificuldades (ou especificidades, se lidas em outra perspectiva) de modernização e de democratização brasileiras na chave explicativa da falta e da incompletude. Tal formulação ancorava-se na leitura do processo de desenvolvimento econômico e transformação da estrutura e da sociabilidade políticas através da superação do passado brasileiro, nomeado como colonial, escravista, rural, atrasado, arcaico, marcado pela violência privada no mundo público. Todos esses atributos deveriam ser superados pela modernidade vindoura, assim como, extrapolando o argumento, supunha-se deveriam ser superados os grupos e/ou camadas sociais que corporificavam esse atraso. Entretanto, esse passado parecia resistir e impregnar as novas e desejadas formas de sociabilidade brasileira - modernas, bemfrisado.

A questão que se coloca e ajuda a compreender a própria constituição dessa experiência de participação popular em Belém (e suas diferenças, inclusive, em relação a outras cidades) é o próprio conteúdo e a maneira como esses assuntos e seus sujeitos foram mobilizados na aposta política que se pretendeu naquela experiência. De certa maneira, o que se colocou no centro da vida política nos interroga sobre a possibilidade de politização e publicização da pobreza e desta nossa "herança arcaica" (Telles, 2001).

No curso da experiência de participação popular em Belém, os movimentos que disputaram os rumos do Congresso da Cidade, mobilizaram e colocaram na cena política tudo aquilo que, segundo uma parte expressiva da literatura sociológica, seria superado 
pela modernidade brasileira: a tradição indígena, a tradição dos negros escravizados, a tradição das revoltas populares, suas formas de viver e de se expressar. Essa participação dos "sem-parcela" num processo de debate e planejamento público justamente em um período de afirmação da democracia representativa e de consolidação da face moderna do Brasil, nos indaga sobre a nossa própria formação social e sobre os impasses da construção de um projeto nacional.

Em toda discussão social em que há efetivamente algo a discutir é essa estrutura que está implícita, essa estrutura na qual o lugar, o objeto e os sujeitos da discussão estão, eles próprios, em litígio e têm primeiro de ser testados. Antes de qualquer confronto de interesses e de valores, antes de qualquer submissão de afirmações a pedidos de validade entre parceiros constituídos, há o litígio em torno do objeto do litígio, o litígio em torno da existência do litígio e das partes que neles se enfrentam. [...] A afirmação de um mundo comum efetua-se assim numa encenação paradoxal que coloca juntas a comunidade e a não comunidade (Rancière, 1996: 65-66 [grifos meus])

Afinal, a partir de quais culturas e perspectivas encenamos e constituímos a vida pública brasileira? 
considerações finais

Olhar o Brasil desde Belém

\section{Subjetivação política: o fio de uma pesquisa}

O debate sobre a democracia que o Congresso da Cidade suscita, tanto em relação a sua própria dinâmica como apontando questões para o conjunto do país, emerge desta perspectiva para a qual

A democracia é, em geral, o modo de subjetivação da política - se por política entende-se coisa diferente da organização dos corpos em comunidade e gestão dos lugares, poderes e funções. Mais precisamente, democracia é o nome de uma interrupção singular dessa ordem da distribuição dos corpos em comunidade que nos propusemos conceituar sob o conceito ampliado de polícia. É o nome daquilo que vem interromper o bom funcionamento dessa ordem por um dispositivo singular de subjetivação. [...] As formas da democracia são as formas de manifestação dessa aparência, dessa subjetivação não identitária e dessa condução do litígio (Rancière, 1996: 102-104).

O movimento conflitivo de constituição da cena pública nos interpela e expõe o seu avesso, o "ódio à democracia", o descredenciamento da política tornada gestão, polícia",

\footnotetext{
${ }^{1}$ Polícia é um termo que Rancière utiliza em oposição à política. Os mecanismos policiais são para o autor forma de disposição de corpos e modos de ser, contrapostos à lógica política da igualdade contingente: "A polícia é assim, antes de mais nada, uma ordem dos corpos que define as divisões entre os modos do fazer, os modos de ser e os modos de dizer, que faz com que tais corpos sejam designados por seu nome para tal lugar e
} 
erosão do sentido de igualdade. Duas lógicas (da política e da polícia) que nas gestões municipais, genericamente percebidas, se enfrentam; uma como resistência e a outra como potência.

A experiência democrática em Belém é resistência, entendida como horizonte e prática política, mas aquela se desenvolve hoje num cenário de descredenciamento desta. Em tempos de consenso e de anulação da política e da fala, é quase um ato de féz perceber pequenos e cotidianos avanços contrários a essa tendência³.

Jacques Rancière (2005) mobiliza parte de sua teorização sobre a política já desenvolvida principalmente em $O$ desentendimento, para enfrentar uma nova-velha questão: o ódio à democracia4.

O duplo discurso sobre a democracia não é certamente novo. Nós estamos acostumados a ouvir que a democracia era o pior dos governos à exceção de todos os outros. Mas o novo sentimento antidemocrático dá a fórmula uma versão mais perturbadora. 0 governo democrático, nos dizem, é nefasto/mau quando ele se deixa corromper pela sociedade democrática que quer que todos sejam iguais e todas as diferenças respeitadas. [...] 0 novo ódio à democracia pode, então, resumir-se em uma tese simples: há somente uma democracia boa, aquela que reprime a catástrofe de uma civilização democrática (Rancière, 2005: 9-10 [tradução minha]).

A chave para compreensão desse novo ódio não é a desmontagem de uma armadilha discursiva 5 , ou, como diz o próprio Rancière, "não se trata de descobrir uma forma de

tal tarefa; é uma ordem do visível e do dizível que faz com que esta atividade seja visível e outra não o seja, que essa palavra seja entendida como discurso e outra como ruído. [...] A polícia não é tanto uma 'disciplinarização' dos corpos quanto uma regra de seu aparecer, uma configuração de ocupações e das propriedades dos espaços em que essa ocupações são distribuídas" (Rancière, 1996: 42 [grifos do autor])

${ }^{2}$ A expressão é de Antonio Gramsci (1995: 23).

${ }^{3}$ Necessário chamar para o debate sobre a formação da classe que aqui aparece tanto E. P. Thompson quanto J. Rancière, os quais enfrentam a tradição marxista tributária do estruturalismo althusseriano e posicionam-se contra uma leitura dos sujeitos políticos como produto direto e imediato de sua posição econômica. A construção de um sujeito político não está posto a priori, nem é um dado de realidade. A leitura da temporalidade concernida no Congresso da Cidade ganha relevância na medida que este não é observado como o lugar de aparecimento de uma classe trabalhadora pronta, nos moldes do industrialismo ou do desenvolvimento econômico stricto senso, e sim como um momento de sua longa formação.

4 Agradeço à Vera Pallamin pela leitura compartilhada do texto $O$ ódio à democracia, como parte da preparação de um seminário apresentado no conjunto de debates do projeto "Hegemonia às avessas" (20072009), sediado no Cenedic. Na preparação para o seminário, tive a oportunidade de discutir com Vera este e outros textos de Rancière e, neste percurso, descobrir nuances importantes do autor. 
ideologia contemporânea" (2005: 10). Ele aposta que, ao compreender a formação desse ódio, compreenderemos também o "nosso mundo e o que nele tem se entendido por política", além de entender "positivamente o escândalo que pesa sobre a palavra democracia e redescobrir o essencial de sua ideia" (Rancière, 2005: 10 [grifo meu]).

As notícias divulgadas pelos meios de comunicação mundiais e os debates sobre uma suposta vitória da "democracia" no Oriente Médio, com as então recentes eleições no Iraque, são o ponto de partida para Rancière demonstrar como o deslocamento em torno do que se compreende por democracia não é nem pura ideologia nem autoritarismo disfarçado. Para ele, a operação em andamento é mais sutil: trata-se da construção de uma nova compreensão da democracia que se ancora na experiência social desta como excesso e como necessidade de contenção, que se sobrepõe à noção e à experiência de democracia com o reino dos indivíduos e das necessidades ilimitadas ${ }^{6}$. Portanto, o argumento central de Rancière acerca da formação e da experiência contemporânea desse novo ódio nos remete ao deslocamento da noção de democracia, o qual inverte o sentido primeiro e originário desta como contestação de toda desigualdade presente na vida comunitária, que é a própria política. Em outras palavras, esse deslocamento opera a perda do sentido da democracia e da política e assim erode a potência (e o excesso ${ }^{7}$ ) da igualdade de toda palavra/fala e da própria experiência democrática.

\footnotetext{
5 Rancière (1996) discute o papel e o significado da ideologia sem negar a herança marxista; muito pelo contrário, como um "leitor refinado de Marx" (a expressão é de Francisco de Oliveira em seminário de debate do projeto de pesquisa "Hegemonia às a

vessas"), ele resgata a elaboração primeira deste acerca da ideologia, afastando-se de leituras que a entendem como simulacro e ilusão: "ideologia é a palavra que assinala o estatuto inédito da verdade forjada pela metapolítica: a verdade enquanto verdade do falso: não a clareza da ideia em face da obscuridade das aparências; não a verdade como indício de si mesma e da falsidade mas, ao contrário, a verdade da qual só o falso é indício: a verdade que nada mais é que evidenciação da falsidade, a verdade como parasitagem universal. Ideologia é então tudo menos um nome novo para uma velha noção. Ao inventá-la, Marx inventa para um tempo que ainda dura um regime inaudito do verdadeiro, e uma conexão inédita da verdade no político. Ideologia é nome da distância indefinidamente denunciada das palavras e das coisas, o operador conceitual que organiza as junções e as disjunções entre os elementos do dispositivo político moderno" (Rancière, 1996: 92-93 [grifos no original]).

${ }_{6}$ Em sua tese de doutorado, recentemente publicada, Edson Miagusko explora essa associação entre democracia e excesso. Para compreender a rejeição ou o descredenciamento das ações públicas dos movimentos de moradia e de sem-teto na Grande São Paulo, assim como suas escolhas políticas, constrói a noção de encolhimento do possível, mostrando como, neste contexto encolhido, a única forma de aparecimento dos "sem-parcela" é o excesso (Miagusko, 2012).

7 Para discutir o escândalo que a democracia é e provoca, Jacques Rancière utiliza também a ideia de excesso democrático, que consiste justamente na afirmação de uma igualdade contingente, de "qualquer um com qualquer um", o que um alargamento real e metafórico da política (cf. Rancière, 2005).
} 
Rancière (2005) identificará um dos pontos fundamentais da torção operada na cena atual para tornar a palavra e a experiência da democracia esvaziada do sentido de igualdade no interior do debate sobre democracia na França, o qual é profundamente marcado pela ideia de república francesa. Neste sentido que precisa ser apreendida a tensão estabelecida neste texto entre democracia e república, que será elaborada a partir da leitura de Rancière de $A$ república de Platão.

Nessa leitura, Rancière discute as concepções platônicas acerca da política, da república, do bom governo e trata, sobretudo, da oposição deste à democracia, de um lado, para afirmar sua própria noção de democracia e seu princípio constitutivo da igualdade e, por outro, demonstrar como Platão (e, portanto, toda a tradição republicana) mantém nostalgicamente a presença do pastor (ou seja, a não política) no centro de sua noção de política, "de onde serve de referência para desenhar a oposição entre o bom governo e o governo democrático" (Rancière, 2005: 41).

Essa presença do pastor no centro da vida política republicana supõe uma desigualdade anterior que aparece como virtude, fundamento da hierarquia que habilita somente alguns para a vida pública e para a política. Essa necessidade, estipulada pelo filósofo grego, de virtudes e habilitações prévias para o exercício do governo, é aquilo que hoje, na experiência política atual, está no centro da associação contemporânea entre democracia e excesso.

Porém, em A república, a despeito dessa desigualdade fundamental pressuposta na enumeração dos títulos para a escolha dos cidadãos aptos para o exercício da política, através do sétimo deles, o sorteio, Platão reintroduz a pura contingência que, segundo Rancière, é, a um só tempo, o escandaloso da democracia - o reconhecimento de que inexiste qualquer título (seja de nascimento, antiguidade ou conhecimento) que habilite os homens previamente para o governo - e o coração da política - a igualdade como seu pressuposto e fundamento. A democracia não é um regime centrado no capricho dos meninos, dos escravos ou dos animais - imagens usadas por Platão para falar da democracia. A democracia é justamente a perda da mensuração da comunidade política dada pela "natureza que emprestava sua lei ao artifício comunitário através de relações de autoridade que estruturam o corpo social" (Rancière, 2005: 48). A democracia é um governo anárquico fundado sobre a ausência de todo título para governar. 
Ademais, essa igualdade contingente não é uma ficção. Toda experiência social de desigualdade está permeada por uma experiência rebaixada de igualdade, ela está pressuposta na desigualdade na medida que, para que os processos de submissão sejam efetivos, as ordenações precisam ser entendidas pelos "desiguais", num processo de legitimação da obediência que supõe a igualdade como base de entendimento entre mandantes e mandados. Essa relação intrincada é revelada justamente pelo "escândalo democrático" na qual se aciona a igualdade, justamente como contingência questionadora (e desestabilizadora) da experiência social da contagem das parcelas ${ }^{8}$.

Interessa reter dessa constituição do ódio à democracia, o cenário que essa perspectiva dispõe e que nos faz considerar com outros olhos o que está ao nosso redor, e, para os fins desta tese, nos leva a interrogar: se vivemos, nos termos de Rancière, num mundo de descredenciamento da política e da democracia, o que significa uma experiência como aquela que aqui retomamos? Até onde podemos supor que essa forma de participação democrática se efetiva e nos leva? Ou antes, seja levada por aqueles que operaram esta encenação política?

8 Como o próprio Rancière indica, essas pequenas sínteses de afirmações e definições sobre a política desnaturalizam a assimilação da democracia a um sistema de governo ou de representação. Essa desnaturalização implica que a mera polaridade entre democracia direta e democracia representativa é, no mínimo, uma redução da questão da representação e do poder. Por um lado, a oposição disseminada à democracia direta verbaliza a ideia de que essa forma de experiência política é boa apenas para as cidades gregas da Antiguidade, ou seja, para sociedades supostamente menos complexas e menores do que as contemporâneas. Por outro, a defesa da democracia representativa como a forma mais conveniente da política obscurece o fato de que toda representação é uma forma oligárquica de aparecimento de uma minoria - seja ela econômica, de nascimento ou de ordens - para ocupar e exercer o poder sobre os assuntos comuns; nesse sentido, ela seria o exato oposto da democracia, a saber, a representação de alguns. Isto, entretanto, não nos autoriza a dizer que a democracia, uma vez que não se identifica imediatamente a uma dessas formas políticojurídicas, seja tão somente indiferente a todas elas. Para Rancière, o poder do povo está aquém e além delas. Aquém, na medida que essas formas não podem funcionar sem referir-se ao poder do povo e à igualdade que funda a não igualdade. Além, porque as formas que inscrevem esse poder são constantemente apropriadas pelo jogo oligárquico que tende à indistinção entre público e privado. Nesse ponto, é importante frisar que Rancière, ainda que na discussão sobre a democracia, retome esse tema caro a Hannah Arendt (a separação entre público e privado) ou que busque nos mesmos textos (como os políticos de Aristóteles) referências para esse debate, ele se afasta das concepções sobre a política e democracia dessa autora. Rancière, ao mesmo que não descarta a lutas sociais, coloca a tensão entre público e privado em um lugar diferente do que Arendt ao não aceitar o suposto apartamento da vida política a um espaço especial, reservado para homens bons e puros. Ao contrário, a tensão entre público e privado é retomada por Rancière para defender o alargamento de sujeitos e espaços políticos. A política, em uma nítida contraposição à Arendt, não tem assuntos, mas sujeitos - quaisquer que interrompam a ordem da dominação. 0 acento de Rancière é, portanto, menos no que será debatido e mais nos processos de subjetivação política que suportam esse embate. 0 movimento democrático é duplo: alargamento da igualdade do homem público para outros homens, mas também a afirmação de pertencimento de qualquer um à política. 
Se há razão em afirmar que o ódio à democracia é elemento estruturador da cena política contemporânea, há que se considerar, por outro lado, que a envergadura do que se publicizou no Congresso da Cidade em Belém não é pequena. Contraposição que se dirige à raiz do problema que abordamos.

Essas inquietações levantadas acima nos levam a perguntar desde o Congresso da Cidade e dos "atos singulares e precários" daqueles sujeitos que deram corpo e sangue a essa experiência política, sobre aquilo que reconhecemos como nossa formação social e sociabilidade política brasileira. Assim, gostaria de argumentar que o Congresso da Cidade dirige-se ao centro da sociabilidade política brasileira: a desigualdade, a impossibilidade de grupos, povos, movimentos, setores inteiros da população brasileira serem "contados". Em Belém, tomaram lugar nos mecanismos de participação popular grupos, setores, povos (organizados ou não) que, na literatura sobre a formação social brasileira, pelo menos desde o final da escravidão e proclamação da República, foram figurados como o atraso.

\section{Desigualdade na sociabilidade política brasileira: outra ponta do fio}

Não pretendo fazer aqui uma leitura exaustiva e tampouco nos marcos da "crítica genética" dos textos e autores do campo do pensamento brasileiro. É preciso dizer que esta não é uma tese sobre o que hoje conhecemos como o campo disciplinar do pensamento social e político brasileiro, assim como não tratará minuciosamente de um ou outro autor desse campo. As anotações aqui expostas procuram fazer dialogar o objeto desta tese com questões que emergiram de minhas leituras sobre a formação social brasileira. Tais preocupações ganham carne e sangue no campo de pesquisa que ao longo deste trabalho fui delimitando assim como estão profundamente imbricadas com a própria construção do Congresso da Cidade como objeto sociológico.

É neste sentido e ciente das limitações de uma leitura como a proposta aqui, que o livro de Maria Sylvia Carvalho Franco, Homens livres na ordem escravocrata, parece instigante e potente para os fins deste trabalho. 0 interesse por sua leitura reside no fato de que a autora lê a desigualdade como elemento estruturador da política no país. Este é o centro do argumento que aqui pretendo discutir. 
Inicialmente escrito como tese de doutoramento, defendida em 1964 na USP sob a orientação de Florestan Fernandes, Homens livres na ordem escravocrata foi publicado pela primeira vez em 1969, pelo Instituto de Estudos Brasileiros da USP. Apesar de ser um estudo que tem como objeto empírico a "velha civilização do café” no século XIX, no Vale do Paraíba, sua atualidade parece residir justamente na capacidade de falar para além de seu recorte geográfico específico; é um estudo rigorosamente sociológico que, partindo de processos-crimes da cidade de Guaratinguetá, compreende e articula três dimensões de análise: a sociedade, o Estado e o mercado, chegando a elaborações que não ficam circunscritas à dimensão local ou comunitária.

Importa dizer que Maria Sylvia recusa a filiação desse seu texto aos estudos de comunidade, uma vez que estes tenderiam a apartar aquelas ditas comunidades analisadas de seus contextos e da sociedade brasileira e, portanto, perder-se-ia a possibilidade da compreensão de continuidades e descontinuidades nas relações sociais e dos processos de mudança social em curso no Brasil. Por outro lado, é preciso ter cuidado na caracterização desses textos como estudos de sociologia rural estrito senso, uma vez que mesmo debruçando-se sobre realidades ou situações do campo, sua perspectiva de análise posiciona-se numa área de fronteira (ou de encontro e de mútua determinação) entre o mundo agrário e a sociedade industrial moderna e urbana em formação.

O interesse inicial pela tese de Maria Sylvia reside na compreensão (apreendida de sua leitura) de nossa formação social não como uma incompletude ou como uma sociedade moderna que guarda traços atrasados ou arcaicos, entraves para seu desenvolvimento. É a própria autora que argumenta em favor de um tipo de leitura menos estanque desses "traços" supostamente de atraso no conjunto do desenvolvimento brasileiro:

pretendi também esclarecer como no interior mesmo da sociedade brasileira aspectos "tradicionais" sofreram uma redefinição de sentido ao dar-se o deslanche da produção mercantil, mantendo-se constante a sua forma. nesses termos, o que se observa é uma continuidade do "velho" para o "novo", uma rapidez nas transformações, em lugar das "resistências a mudança" que em geral se aponta. Levando adiante essa linha de observação, procurei esclarecer como o conjunto de elementos que formalmente poderiam ser identificados como tradicionais apenas se torna 
legível quando referido à produção lucrativa (Franco, 1997: 18 [grifos no original]).

Neste sentido, é possível afirmar que Franco (1997) afasta-se da tradição de pensamento que compreende o Brasil e sua formação social tanto como incompletude, como é possível ler nos textos de Oliveira Vianna ou ainda de Sérgio Buarque, quanto na chave dual e dicotômica.

Werneck Vianna (1999) discute a recepção de Weber no Brasil, identificando duas leituras opostas do processo de modernização brasileiro na chave/perspectiva do atraso: de um lado, Raymundo Faoro e Simon Schwartzman e de outro, Florestan Fernandes e Maria Sylvia de Carvalho Franco. Faoro e Schwartzman, ao considerarem o "patrimonialismo como um fenômeno do Estado" (1999: 38), identificam o atraso com a instância do político e perdem de vista as relações societais que se estabelecem entre atraso e moderno, lidos desta perspectiva como uma oposição e não como uma combinação. No outro polo da recepção weberiana, Maria Sylvia e Florestan compreenderiam essas mesmas relações entre atraso-moderno, no quadro do desenvolvimento do capitalismo no país, não "em contraposição agonística", mas de forma combinada. 0 Estado patrimonialista nessa perspectiva não é lido como um ente a priori, imposto à sociedade no Brasil, mas resultado das relações que se desenvolvem naquele tecido social. 0 atraso e o moderno são assim, analisados desde o ponto de vista da sociedade, interrogando essa imbricação e como ele se condensa no Estado.

Vale a pena seguir um pouco a argumentação de Werneck sobre Maria Sylvia e Florestan para constatar que o autor sustenta que das leituras destes depreendemos a permanência do atraso, representado pelas oligarquias agrárias incrustadas no Estado, no seio de uma modernização fomentada por "novas elites" industriais e urbanas. Gostaria de chamar atenção que na leitura detalhada e profunda do texto de Franco (1997), Werneck Vianna identifica na dominação pessoal o elemento significativo, fundamental, para a permanência do atraso no âmbito da sociedade brasileira em formação.

Dois aspectos tratados de forma condensada na introdução de Franco (1997) são importantes para compreensão da figuração da formação social brasileira que emerge dele, a saber: a tese sustentada aí sobre escravidão e a relação entre "produção direta dos meios 
de vida" (economia de subsistência) e "produção de mercadorias" (produção mercantil), compreendida como unidade contraditória. Esses dois aspectos autorizam a leitura do processo de formação social do Brasil como um processo não disjuntivo ${ }^{9}$, que rompe com a percepção de uma formação social dual, especialmente no que diz respeito à relação entre Estado e sociedade.

Como o título do livro já anuncia, a autora não trata abertamente dos escravos e nem da escravidão, mas sim concentra sua análise nos homens livres e pobres que "não conheceram os rigores do trabalho forçado e não se proletarizaram" (Franco, 1997: 14), mas que conheceram fundamente a violência e a desigualdade, constituindo-se como uma "ralé". A caracterização dos homens livres e pobres afasta-os da noção de dispensabilidade absoluta, ainda que não sejam ou estejam no centro da economia de mercado, compreensão de seu lugar é feito na tensão marginalidade constitutiva - aproveitamento residual.

O que está em questão em Franco (1997) não é o enigma de uma formação social cujo suposto truncamento deveria ser tomado como especificidade ou como impeditivo na tarefa de superação do atraso em direção a uma sociedade moderna e democrática. Seu foco parece ser a compreensão das tensões e diferenças que dão corpo à nossa especificidade, arranjam-se e combinam-se numa formação social concreta e como esta se articula com o sistema econômico no qual o Brasil está inserido - afastando-se assim de uma "sociologia da inautencidade"10 (cf. Souza, 2000).

Na Introdução de Homens livres na ordem escravocrata, a autora anuncia a tese central do livro: a violência que "aparecia por toda a parte" (Franco, 1997: 17) nos processos-

\footnotetext{
${ }^{9} \mathrm{O}$ termo é de André Botelho em sua exposição sobre Maria Sylvia de Carvalho Franco, no curso Pensamento político-social brasileiro, ministrado na FFLCH-USP, em 19 de novembro de 2009.

10 Jessé Souza (2000) propõe a leitura de três autores consagrados do pensamento brasileiro - Sérgio Buarque, Raymundo Faoro e Roberto DaMatta - de maneira a concluir que todos os três leem o processo de modernização de modo a configurar o que denominou de sociologia da inautenticidade, uma vez que para Souza estes autores utilizam-se de categorias deslocadas do processo social concreto que pensam e encerram o Brasil - cada um a sua maneira - dentro de "um quadro de modernização inautêntico ou epidérmico. [...] Se estamos corretos em supor que a relação das ideias com o mundo material não é de exterioridade, mas, ao contrário, que as ideias ajudam a construir a própria realidade material, na medida em que nos mostram alguns aspectos e possibilidades de ação e encobrem outros tantos, então a crítica das ideias é uma tarefa conspícua de uma sociologia com interesses críticos. Estou convencido de que o que venho chamando de nossa sociologia da inautenticidade representa uma forma unilateral, incompleta e enviesada de perceber nossa realidade" (Souza, 2000: 167-168).
} 
crimes consultados mostrava-se como elemento constitutivo das relações e não somente nas situações de crime especificamente. Concentrando-se no estudo sobre os homens livres e pobres nessa sociedade, Maria Sylvia mostra como a violência nas relações mais cotidianas estruturam a vida e a própria experiência de mundo que aqueles homens tiveram, situandoa para além de uma forma de regulação comunitária em períodos de crise ou em situações de defesa pela sobrevivência. De outra maneira, pelo lugar lateral que ocuparam na produção, pela precariedade e penúria na qual viviam, esses homens tiveram a experiência de constituição de si marcada por uma forte experiência subjetiva, sem a constituição de um "mundo exterior" que pudessem conduzir as relações com o outro. "Em seu mundo vazio de coisas e falta de regulamentação" (Franco, 1997: 62), a violência então se constitui como componente estrutural da e na sua relação com o mundo e com os homens, no sentido de que se torna sua única forma de experimentar a vida no mundo, através de sua coragem e valentia.

Há uma novidade no tratamento da violência e da desigualdade na tese de Maria Sylvia, especialmente se considerarmos os autores de extração conservadora do pensamento brasileiro. A violência, que não deveria ser uma surpresa em processos-crimes como a autora nos adverte, é tratada como um elemento analítico que abre a possibilidade de leitura da própria sociedade na qual ela aparece. A análise da violência empreendida pela autora extrapola os limites de uma sociologia da violência ou, ainda, permite uma leitura do Brasil a partir de sua história social num determinado momento, mas numa perspectiva de compreensão de sua formação social e suas mediações. A violência que emerge do material de campo coletado não é tomado como o desvio em situações de quebra da normalidade das relações; a violência é tratada no bojo das situações concretas nas quais ela aparece revelando mais do que tensões momentâneas no contexto de uma comunidade autorregulada. Essa perspectiva assumida pela autora me parece só ser possível no conjunto de sua orientação geral de compreensão da sociedade brasileira por um viés positivo e não dicotômico.

A análise da dominação pessoal empreendida por Franco (1997) a concentra-se em três tipos sociais diferentes: os tropeiros e vendeiros; os sitiantes e os agregados e camaradas. A figura do homem livre e pobre será projetada no sistema social, vinculando-os 
ao conjunto do sistema social no qual estão inseridos. A organização do sistema de produção cafeeira que comportava, nas suas franjas, "serviços residuais, que na maior parte não poderiam ser feitos por escravos e não interessavam aos homens de patrimônio" (Franco, 1997: 65) significaram a possibilidade de alguma integração desses homens através de oportunidades de trabalho livre, não assalariado, nos marcos formais das relações de mercado. Essa inserção lateral ou residual, para usar os termos da autora, marca juntamente com outros aspectos, este "lugar sem-lugar" que estes tipos ocuparam: uma inserção que comporta de fato um lugar diferenciado em relação aos caipiras de modo geral e algum grau de autonomia em relação aos senhores de terra, mas que reproduz formas de dominação e desigualdade em muitas dimensões.

As relações entre os tropeiros e os proprietários de terras cafeicultores davam-se basicamente em função do transporte da carga do café e abastecimento das fazendas em lombo de burros e situava-se na imbricação entre uma tecnologia rudimentar referida a economia de subsistência e o grande empreendimento mercantil e suas operações comerciais. Lugar paradigmático onde a superfluidade dos homens pobres e livres é em certa medida contestada, contudo reafirmada em seguida. Algo aparentemente contraditório, dada a natureza da relação de mercado que se estabelece, mas que nos dá a chave para acessar a forma como se conjugam liberalismo e dominação no Brasil. A dependência do tropeiro em relação ao proprietário fazia-se presente na cessão de terras para criação de seu rebanho ou de alojamento para os seus durante o transporte, obrigando o tropeiro a retribuir os benefícios recebidos. Dessa maneira, uma linha de dependência "tênue, mas forte" matiza a sua suposta liberdade e igualdade na relação mercantil com os proprietários, e dá sentido à advertência que a autora faz em relação ao conceito de liberdade:

Assim, esse conceito de liberdade só poderá ter seu conteúdo precisado à luz do regime de propriedade, apreendido não apenas através de sua expressão codificada, que prescreve direitos "formais", mas sobretudo através das condições que regulam a distribuição efetiva do poder, desvendando-se assim os limites dos direitos "vividos". Em resumo, o conceito genérico de liberdade implícito nas relações de mercado, que é afirmado no princípio da propriedade privada, só poderá alcançar teor 
explicativo quando nuançado em função do sistema de dominação a que se conjuga (Franco, 1997: 68).

0 que matiza esse conceito liberal de liberdade é justamente a violência constitutiva que as condições concretas de vida neste país engendram: relações que partem do suposto da desigualdade fundante de todo o código de sociabilidade.

Esse mesmo princípio de desigualdade, observamos na relação entre vendeiros e proprietários ou ainda entre estes e sitiantes e camaradas. Os vendeiros na sua posição ambígua ou "oscilante" viviam entre os dois polos, num lugar que estabeleciam relação tanto com os estratos superiores quanto com os inferiores. Essa aproximação que o sitiante permite com os/dos escravos e inferiores o desqualifica aos olhos dos proprietários e engendra sua reprovação. É preciso ainda atentar para o fato que o vendeiro condensa em si uma atividade "marginal e quase dispensável" (Franco, 1997: 80), entre uma economia de mercado e uma economia de subsistência no seio de uma vida comunitária. Ali também a violência está presente, inscrita na moralidade, "gerada pela ordem social e como negadora dessa mesma ordem" (Franco, 1997: 84).

São as relações de compadrio entre sitiantes e fazendeiros que ajudam a revelar um traço importante da forma como a violência e a desigualdade se imbricam e engendram nossa formação social: uma aparência de nivelamento social ou de inexistência de clivagens e diferenciações sociais, mas um profundo apartamento entre os sujeitos, menos pelas suas relações concretas e mais por aquilo que rege e estrutura essa relação. Os laços de compadrio encerram claramente uma dimensão de dominação, estabelecendo uma rede de dívidas e obrigações, entretanto, guardam uma dimensão de equivalência entre as partes daí o suposto nivelamento de posições hierárquicas.

E é justamente essa tensão que explica ou explicita as formas (estas, sim, estáveis) de dominação política: o reconhecimento social cotidiano dos homens livres como pessoa negava a própria humanidade deles, uma vez que os encapsulava numa teia de obrigações e favores que os compelia a "comportamentos automáticos, de onde o critério, o arbítrio e o juízo estavam completamente excluídos" (Franco, 1997: 93), base de sustentação para a perenidade da dominação política dos fazendeiros e a filiação política dos sitiantes a eles. 
Esta parece ser a questão central de Franco (1997) para compreensão da formação social brasileira: a articulação entre violência e desigualdade como padrão de sociabilidade política. A dominação pessoal emerge assim, como código estruturador na formação social brasileira.

Entretanto, gostaria de propor um deslocamento dessa perspectiva: por detrás das formas concretas de dominação descritas e analisadas por Franco (1997), há uma articulação, nos moldes de uma unidade contraditória, entre os pressupostos sobre as quais se constituem as relações entres esses grupos sociais diferentes, ou seja, entre igualdade e sua negação, a desigualdade. Em certa medida, a dominação pessoal seria o resultado que essa articulação igualdade-desigualdade estrutura e menos o seu pressuposto.

Não significa dizer, entretanto, que a dominação pessoal não opere ou que deva ser considerada menor em relação ao seu mecanismo fundante. Argumento que a dominação pessoal opera no duplo mecanismo de coerção e convencimento, e que é justamente no polo do convencimento (ou do consenso, para utilizar uma noção cara a Rancière) - a desigualdade ou a negação da igualdade política - que está o mecanismo mais poderoso de legitimação social das formas subalternas de relação entre os homens livres e pobres e as camadas dominantes.

Esse deslocamento de perspectiva aqui proposto permite iluminar as tentativas de rompimento desta ordem de coisas ao longo da história recente do país. É a desigualdade na sua acepção política nos termos de Rancière, como vimos acima, que funda a dominação, reiterada muitas vezes não só na relação estrita de homens livres e proprietários de terras, mas se espraia para o conjunto das relações sociais nas diversas dimensões (sociedade, Estado e mercado) como padrão de sociabilidade, não necessariamente sob a forma da dominação pessoal descrita por Franco (1997).

Gostaria de argumentar em favor desse deslocamento sinalizando também que, ao tratar diretamente da escravidão, a presença ausente, a autora retoma a figuração dos escravos como não humanos. Dessa maneira mostra como, entre os homens livres e os escravos - guardadas as diferenças -, há algo que funda as duas formas de dominação e violência: a desigualdade sobre a qual se assenta uma e outra e a negação da humanidade de ambos - os escravos diretamente como coisa e os homens livres através da construção 
de uma criatura domesticada. Reproduzo abaixo o longo trecho que, acredito, autoriza essa leitura.

Essas considerações mostram o quanto esse tipo de dominação pode exterminar a vontade do homem a ele submetido e reduzi-lo à inércia. $\mathrm{Na}$ propriedade servil, embora o escravo seja transformado em coisa e a extinção de sua consciência vá ao limite da autonegação como pessoa, existem marcas violentas que denunciam a opressão que sobre ele pesa e nessa medida possibilitam pelo menos um 'vago desejo de liberdade', 'uma mera necessidade subjetiva de afirmação que não encontra condição de realizar-se concretamente' [Cardoso, 1962, cap. III] ${ }^{11}$. Liberdade impossível mas pelo menos desejada, o que devolve ao escravo, embora apenas como projeção individual, um sentido de humanidade. Para aquele que se encontra submetido ao domínio pessoal, inexistem marcas objetivadas do seu sistema de constrições a que a sua existência está confinada: seu mundo é formalmente livre. Não é possível a descoberta de que sua vontade está presa a do seu superior, pois o processo de sujeição tem lugar como se fosse natural e espontâneo. Anulam-se as possibilidades de autoconsciência, visto como dissolvem na vida social todas as referências a partir das quais ela poderia se constituir. Plenamente desenvolvida, a dominação pessoal transforma aquele que a sofre numa criatura domesticada: proteção e benevolência lhe são concedidas em troca de fidelidade e serviços reflexos. Assim, para aquele que está preso ao poder pessoal se define um destino imóvel, que se fecha insensivelmente no conformismo (Franco, 1997: 95 [grifos no original]).

\footnotetext{
11 Franco (1997) reproduz aqui o argumento de Fernando Henrique Cardoso (1962) do escravo como coisa. Essa leitura da escravidão e, sobretudo, suas consequências no plano da vida e da intervenção política, foram contestadas anos depois da publicação do livro de Cardoso. Sidney Chalhoub (1990), utilizando um acervo teórico thompisoniano, especialmente a noção de economia moral - nos mostra como os escravos, negros libertos e negros livres movimentaram-se nos interstícios da Lei de Alforria através de processos judiciais nos quais reivindicavam o reconhecimento de sua condição socialmente legítima de alforriados, construindo em meio a um espaço extremamente opressor e violento, experiências de liberdade. Com sua luta cotidiana, miúda, quase imperceptível nos marcos da macro-história e da história dos heróis, conseguiram criar no seio da sociedade "consagrando pelo costume" (Chalhoub, 1990: 180) condições de vida e experiências que deram substrato social para o final da escravidão. Poderíamos dizer que essas formas de experiência da liberdade conformam junto com as revoltas, insurreições e outras formas de luta dos negros cativos e libertos, uma disputa pelos significados da noção de igualdade e de liberdade no seio daquela sociedade.
} 
Vale ainda sublinhar que na sua caracterização sobre os agregados e camaradas, e mesmo entre os vendeiros e sitiantes, Franco (1997) identifica formas e mecanismos de rompimento com a ordem de dominação. Entretanto, essas saídas são unicamente pessoais: "diante deles [do vendeiro, do tropeiro ou do pequeno proprietário] estavam dados os meios para enriquecer e ascender socialmente numa formação econômica em que progressivamente se determinavam e se cristalizavam as diferenças de fortuna e destino" (Franco, 1997: 111). Note-se que essa saída pelo enriquecimento via mercado ancora-se no mesmo suporte que a educação: a possibilidade de ascensão pela posse ou pela educação, ascensão que significa "ser alguém", uma vez que o sistema de regulação formal não garante, através de direitos ou instituições públicas, essa possibilidade de reconhecimento de seu estatuto de igualdade e apenas fragilmente de sua mobilidade social.

A desigualdade não se encerra com a abolição da escravidão nem mesmo com a constituição de relações de mercado e de assalariamento do trabalho. A "presença ausente" da escravidão aqui é reencontrada como uma presença mesmo. Ou de outra forma, ao tratar da constituição de relações de trabalho mercantis e a consolidação da produção capitalista, as marcas da escravidão aparecem e ressurgem no dito trabalho livre.

Chamo a atenção sobre a integridade desse conjunto feito de moderação e excesso, que esteve presente no tratamento do senhor ao seu escravo, não tanto para iluminar esta relação, que não é objeto deste trabalho, mas para acentuar a referência dos processos socioeconômicos em curso dentro da fazenda ao modo de sua organização, que articulou produção mercantil e produção direta de meios de vida.

Essa referência da escravidão à estrutura global da fazenda encaminha, de maneira correta, o entendimento de um tema que é central neste estudo e que não pode ser tratado independentemente daquela instituição. Refirome ao trabalho, como atividade que atravessou de ponta a ponta a sociedade e impôs-se como requisito mesmo para as classes dominantes. [...] E, reafirmo, tratar-se de uma sociedade escravocrata, em que forçosamente o princípio da separação nítida entre o requisito do trabalho e o privilégio de sua dispensa se fazia fundamental para a própria afirmação do poder. É fora de dúvida que essa amálgama de escravidão e produção 
mercantil, gerida e controlada diretamente pelas camadas privilegiadas, seguiu cheia de ambiguidades e tensões e o ajustamento entre dominados e dominantes definiu-se de maneira complexa no processo de produção. (Franco, 1997: 212-213).

A desigualdade persiste, nesse sentido, como pressuposto, e não somente como efeito, da formação social brasileira.

\section{Um fio, duas pontas e o nó}

Atraso e pobreza: uma persistência nas leituras da formação social brasileira. É certo que a pobreza e o atraso flagrados no final do século XIX e no começo do século XX são muito diferentes da pobreza e das desigualdades sociais contemporâneas. Contudo, essa transformação (comprovada à exaustão pelos levantamentos socioeconômicos que indicam crescimento econômico e melhora das condições de vida da população, mas que não explicita o recrudescimento da concentração de renda, por exemplo) revela mais do que a transformação de um país agrário, recém-constituído e emancipado em um país que se urbanizou e se industrializou, que promulgou direitos sociais e espaços de participação social, enfim, uma sociedade que, apesar da pobreza "persistente", se fez moderna.

A persistência incômoda desse atraso e dessa pobreza (ou seria, a presença incômoda dos atrasados e dos pobres?) revela a forma específica como esta sociedade articulou mecanismos estritamente modernos aos nomeados como atrasados. A formulação de Francisco de Oliveira é a que mais precisamente desvenda essa combinação de atraso e moderno:

O processo descrito, em vários níveis e formas, constitui o modo de acumulação global próprio da expansão do capitalismo no Brasil pós-anos 1930. A evidente desigualdade de que se reveste que, para usar a expressão famosa de Trotsky, é não somente desigual mas combinada, é produto antes de uma base capitalística de acumulação razoavelmente pobre para sustentar a expansão industrial e a conversão da economia pós-anos 1930, que da existência de setores "atrasado" e moderno". Essa combinação de 
desigualdades não é original; em qualquer câmbio de sistemas ou de ciclos, ela é, antes, uma presença constante. A originalidade consistiria talvez em dizer que - sem abusar do gosto pelo paradoxo - a expansão do capitalismo no Brasil se dá introduzindo relações novas no arcaico e reproduzindo relações arcaicas no novo, um modo de compatibilizar a acumulação global, em que a introdução das relações novas no arcaico libera força de trabalho que suporta a acumulação industrial-urbana e em que a reprodução de relações arcaicas no novo preserva o potencial de acumulação liberado exclusivamente para fins de expansão do próprio novo (Oliveira, 1972: 28 [grifos no original]).

E atualizada, foi figurada como o esquisito, mas existente e vivo, bicho ornitorrinco: O ornitorrinco é uma das sociedades capitalistas mais desigualitárias - mais até que as economias mais pobres da África que, a rigor, não podem ser tomadas como economias capitalistas -, apesar de ter experimentado as taxas de crescimento mais expressivas em período longo; sou tentado a dizer com a elegância francesa, et pour cause. As determinações mais evidentes dessa contradição residem na combinação do estatuto rebaixado da força de trabalho com dependência externa. A primeira sustentou uma forma de acumulação que financiou a expansão, isto é, o subdesenvolvimento, conforme interpretado neste [na] Crítica à razão dualista, mas combinando-se com a segunda produziu um mercado interno apto apenas a consumir cópias dando como resultado uma reiteração não virtuosa (Oliveira, 2003: 143).

Em certa medida, essa leitura autoriza uma percepção do país não mais como incompletude e, portanto, o atraso não é uma pedra a ser retirada do caminho, assim com a pobreza não será incorporada ou redimida pelo desenvolvimento e suposto espraiamento dos direitos. Não se trata de um mecanismo truncado. As arestas do processo - o atraso e, portanto, aqueles que carregam as suas marcas, aqueles que se interpõem ao desenvolvimento ou os pobres ainda não beneficiados por suas benesses - não são resquícios de um tempo pré-capitalista, são rigorosamente seus produtos, como 
demonstraram Francisco de Oliveira e, por outro caminho, Maria Sylvia. Os pobres, figurados como o atraso ou o arcaísmo, são assim invisibilizados. Está tudo em seu lugar.

A pobreza sempre documentada e apontada ao longo da história brasileira só pode sair deste lugar de natureza, deslocada do pertencimento da vida política do país, através do esforço desses pobres e atrasados que, figurando-se como trabalhadores, interpuseram se às formas de dominação e exigiram direitos - de formas diversas ao longo dos mais de cento e vinte anos da história recente do Brasil, isto para nos ater ao período de instituição do trabalho livre como o centro da dinâmica econômica.

Mais recentemente, o seu aparecimento como questão social ${ }^{12}$ nos anos 1980 é fruto das lutas que articularam a reivindicação da liberdade política ante a ditadura militar instaurada com o Golpe de 1964, com a reivindicação de justiça social, a partir da noção dos direitos sociais e a construção de políticas públicas universais e com forte acento participativo. Essa politização da pobreza e a aposta que esta supunha, foi pega no contrapé por medidas de ajuste econômico que caracterizaram os anos 1990 e o desmanche do ainda nascente corpo regulatório das políticas sociais ancoradas na Constituinte Cidadã de 1988.

Esta conexão - naturalizada - entre atraso e pobreza, tantas e muitas vezes reiteradas nas leituras sobre a formação social brasileira, é nó do enigma e que desfeito expõe a desigualdade política ou a negação da igualdade contingente que lhe constitui. Este nó só pode ser desfeito à medida que o processo de subjetivação política se imponha e desfaça a organização de corpos e falas no espaço social brasileiro.

Essa impossibilidade de igualdade, ou seja, a concretude da desigualdade, é o centro da contestação ao qual se dirige a reparação do dano. A entrada de mulheres e homens não contados na cena política expõe e questiona justamente essa sobreposição entre atraso e pobreza e a conexão imediata entre atraso e o povo. Essa pobreza desencarnada, tornada natureza que justamente permite a figuração do povo como portador deste atraso. Afinal, são estes que se põem em pé e se constituem como sujeito nos processos de participação política que flagramos em Belém, no Congresso da Cidade.

É uma fresta por onde se pode ver - e apostar - em desarmar este nó.

\footnotetext{
${ }^{12}$ Esse momento foi também de grande importância para conjunto das ciências sociais no Brasil, haja vista o debate que retomamos no capítulo3 desta tese, sobre os sujeitos políticos no período.
} 


\section{Referências bibliográficas}

ABENSOUR, Miguel. (1998). A democracia contra o Estado: Marx e o momento maquiaveliano. Belo Horizonte: Ed. da UFMG.

ACSELRAD, Henri. (2010). "Ambientalização das lutas sociais: o caso do movimento por justiça ambeintal." Estudos Avançados, v. 24, n. 68, pp. 103-119.

. (2004). "As práticas espaciais e o campo dos conflitos ambientais". In: (org.).

Conflitos ambientais no Brasil. Rio de Janeiro: Relume Dumará: Fundação Heinrich Böll.

"Sobre os usos sociais da cartografia". Disponível em: http://conflitosambientaismg.lcc.ufmg.br/geral/anexos/txt_analitico/ACSELRAD_Hen ri_-_Sobre_os_usos_sociais_da_cartografia.pdf

ALMEIDA, Alfredo Wagner Berno de. (2004). "Amazônia: dimensão política dos 'conhecimentos tradicionais'”. In: ACSELRAD, Henri. (org.). Conflitos ambientais no Brasil. Rio de Janeiro: Relume Dumará: Fundação Heinrich Böll. - (2010). "Conhecimentos tradicionais: Uma nova agenda de temas e problemas. Conflitos entre o poder das normas e a força das mobilizações pelos direitos territoriais". In: et al. (orgs.). Cadernos de debates Nova Cartografia Social: conhecimentos tradicionais na Pan-Amazônia. Manaus: Projeto Nova Cartografia Social da Amazônia: UEA Edições. (Vol. 01, no . 01).

ALMEIDA, Alfredo Wagner Berno de; MARIN, Rosa Acevedo. (2010). "Campanhas de desterritorialização na Amazônia: o agronegócio e a reestruturação do mercado de terras". In: BOLLE, Willi; CASTRO, Edna; VEJMELKA, Marcel. Amazônia: região universal e teatro do mundo. São Paulo: Globo. 
ARANTES, Paulo (1992). Sentimento de dialética. Rio de Janeiro: Paz e Terra. ; ARANTES, Otília. (1997). Sentido de formação. Três estudos sobre Antonio Candido, Gilda de Mello e Souza e Lúcio Costa. Rio de Janeiro: Paz e Terra.

ARANTES, Otília; VAINER, Carlos; MARICATO, Ermínia. (2000). A cidade do pensamento único: desmanchando consensos. Petrópolis: Vozes.

ARAÚJO, Ricardo Benzaquém de. (2009). "Caminhos de Sérgio Buarque de Holanda". In: BOTELHO, André, SCHWARCZ, Lília. Um enigma chamado Brasil: 29 intérpretes e um país. São Paulo: Companhia das Letras.

ARENDT, Hannah. (1987). Homens em tempos sombrios. São Paulo: Companhia das Letras.

AVRITZER, Leonardo (org.). (2007). A participação social no Nordeste. Belo Horizonte: Editora UFMG. . (2004). A participação em São Paulo. São Paulo: Ed. da Unesp. - (2002). "O orçamento participativo: as experiências de Porto Alegre e Belo Horizonte". In: DAGNINO, Evelina (org.). Sociedade civil e espaços públicos no Brasil. São Paulo: Paz e Terra.

. (1994). Sociedade civil e democratização. Belo Horizonte: Del Rey. . (s/d). $O$ orçamento participativo e a teoria democrática: um balanço crítico. Relatório de pesquisa "A inovação democrática", UFMG, Belo Horizonte. Disponível em $<$ http://www.democraciaparticipativa.org/files/LeonardoAvritzer-

Oor\%E7amentoparticipativoeateoriademocr\%E1ticaumbalan\%E7ocr\%EDtico.pdf> BAIERLE, Sérgio. (2000). "A explosão da experiência: emergência de um novo princípio ético-político nos movimentos populares urbanos em Porto Alegre". In: ALVAREZ, Sônia E.; DAGNINO, Evelina; ESCOBAR, Arturo (orgs.). Cultura e política nos movimentos sociais latino-americanos. Belo Horizonte: Ed. da UFMG.

BARBOSA, Mário Médice. (2004). O povo cabano no poder: memória, cultura e imprensa em Belém-PA (1982-2004). 324 p. Dissertação de mestrado em história social. São Paulo: PUC.

BASTOS, Élide Rugai; PINTO, Renan Freitas. (2007). Vozes da Amazônia: investigação sobre o pensamento social brasileiro. Manaus: EDUA. 
BELLO, Carlos Alberto. (2007). "Orçamento participativo em São Paulo: uma invenção de limitado alcance". In: OLIVEIRA, Francisco de; RIZEK, Cibele Saliba (orgs.). A era da indeterminação. São Paulo: Boitempo.

BENJAMIM, Walter. (1994). Magia e técnica, arte e política: ensaios sobre literatura e história da cultura. São Paulo: Editora Brasiliense. (Obras escolhidas, v. 1). $7^{\circ}$ ed.

BOLLE, Willi. (2008). "Belém, porta de entrada da Amazônia”. In: CASTRO, Edna. (org.). Cidades na floresta. São Paulo: Annablume. . (2010). "A travessia pioneira da Amazônia (Francisco Orellana, 1541-1542)”. In: ; CASTRO, Edna; VEJMELKA, Marcel. (org.). Amazônia: região universal e teatro do mundo. São Paulo: Globo.

BOTELHO, André. (2007). "Sequências de uma sociologia política brasileira". Dados, v.50, n.1, pp.49-82. . (2010). "Passado e futuro das interpretações do país". Tempo Social, v.22, n. 1, pp. 47-66.

BRANDÃO, Gildo Marçal. (2005). "Linhagens do pensamento político brasileiro". Dados, v.48, n.2, pp.231-269.

CABANES, Robert; et al. (orgs.) Saídas de emergência: ganhar/perder a vida na periferia de São Paulo.. São Paulo: Boitempo, 2011.

CANDIDO, Antonio. (1987). Os parceiros do Rio Bonito. São Paulo: Duas Cidades. 7a ed.

(1995). "O significado de Raízes do Brasil” in HOLANDA, Sérgio Buarque de Holanda. Raízes do Brasil. São Paulo: Companhia das Letras.

CASTRO, Edna. (2008). "Urbanização, pluralidade e singularidades das cidades amazônicas." In:___ (org.). Cidades na floresta. São Paulo: Annablume.

CASTRO, Edna. (2010). "Políticas de Estado e atores socias na Amazônia contemporânea." In: BOLLE, Willi; CASTRO, Edna; VEJMELKA, Marcel. Amazônia: região universal e teatro do mundo. São Paulo: Globo.

CADERNOS PÓLIS. (2002). Orçamento participativo em municípios paulistas-1997-2000. São Paulo, Pólis. 32p.

CAMPOS, Luiz Arnaldo. A cabanagem como construção de uma identidade revolucionária. Belém: s/d. mimeo. 
; DION, Monteiro (orgs.). (2011). Amazônia: Olhares inquietos na floresta. Rio de Janeiro: Fundação Lauro Campos.

CÂNDIDO, João Carlos. (2002). Entre a 'política' e a 'polícia': a constituição e a crítica da sociedade industrial democrática na sociologia paulista dos anos 1950 e 1960.122 p. Dissertação de mestrado em sociologia. São Paulo: FFLCH-USP.

CARDOSO, Ana Claudia Duarte. (20006). O rural e o urbano na Amazônia: Diferentes olhares em perspectiva. Belém: EDUFPA.

CARDOSO, Fernando Henrique. (1962). Capitalismo e escravidão no Brasil meridional. São Paulo: Difusão Europeia do Livro.

CARVALHO, Guilherme et al. (orgs.). (2004). Políticas públicas e gestão local: programa de capacitação em políticas de desenvolvimento urbano sustentável e gestão democrática. Belém: Fase.

CHALHOUB, Sidney. (1990). Visões da liberdade. São Paulo: Cia das Letras.

CELENTANO, Danielle. (2007). A Amazônia e os Objetivos do Milênio. Belém, PA: Imazon.

CRUZ, Sandra Helena Ribeiro. (1994). Movimentos sociais e construção de espaço urbano em Belém: o bairro da Sacramenta. 164p. Dissertação de mestrado em planejamento do desenvolvimento. Belém: UFPA-NAEA.

CUNHA, Manuela Carneiro da. (1999). "Populações tradicionais e a Convenção da Diversidade Biológica." Estudos Avançados, v.13, n.36, pp.147-163.

. (2011). "Índios como tema do pensamento social brasileiro." In: BOTELHO, André; SCHWARCZ, Lilia. Agenda brasileira: temas de uma sociedade em mudança. São Paulo: Companhia das Letras.

DAGNINO, Evelina (org.). (1994). Anos 90: sociedade e política no Brasil. São Paulo: Brasiliense. . (2002). Sociedade civil e espaços públicos no Brasil. São Paulo: Paz e Terra.

DAGNinO, E., OLVERA, A, PANFICHI, A. (orgs.) (2006). A disputa pela construção democrática na América Latina. São Paulo: Paz e Terra; Ed. da Unicamp.

Encontro Americano pela Humanidade e Contra o Neoliberalismo, II, 1999. Memórias. Belém: Prefeitura Municipal de Belém, 2002.343p. 
ESTERCI, Neide. (2011). "Amazônia: povos tradicionais e luta por direitos". In: BOTELHO, André; SCHWARCZ, Lilia. Agenda brasileira: temas de uma sociedade em mudança. São Paulo: Companhia das Letras.

FAORO, Raymundo (1958). Os donos do poder. Rio de Janeiro: Editora Globo. . (1994). "Existe um pensamento político brasileiro". In: Existe um pensamento político brasileiro? São Paulo, Editora Ática.

FARIAS, Rosa Sulaine Silva. (2004). Planejamento e gestão participativos em Belém-PA: o Congresso da Cidade (2001-2004). 2004. 142 fls. Dissertação de mestrado em planejamento urbano e regional. Porto Alegre: FA-UFRGS.

FERNANDES, Florestan. (1987). A Revolução Burguesa no Brasil. Rio de Janeiro: Editora Guanabara. $3^{\mathrm{a}} \mathrm{ed}$.

FRANCO, Maria Sylvia de Carvalho. (1976). "As ideias estão em seu lugar" in Cadernos de debate, n. 1. . (1997). Homens livres na ordem escravocrata. São Paulo: Ed. da Unesp. $4^{\mathrm{a}}$ ed. . (1981). "Entrevista com Maria Sylvia Carvalho Franco". Revista Trans/Form/Ação, v. 4, p. 5-14.

FREYRE, Gilberto (1951). Sobrados e mucambos. 2a edição. Rio de Janeiro: José Olympio.

FERREIRA, Hamilton. (2004). "Movimentos sociais urbanos em Belém: construindo um histórico e uma agenda de lutas no FMRU". In: SILVA NETO, João Gomes da et al. (orgs). Políticas públicas e gestão local: programa de capacitação em políticas de desenvolvimento urbano sustentável e gestão democrática. Belém: Fase.

HARDMAN, F. (1998). Morte e Progresso: cultura brasileira como apagamento dos rastros. São Paulo: Fundação Editora da UNESP.

HOLANDA, Sérgio Buarque de. (1995). Raízes do Brasil. São Paulo: Companhia das Letras.

GAGNEBIN, Jeanne Marie. (2006). Lembrar escrever esquecer. São Paulo: Ed. 34.

GALVÃO, Georgiana Tolosa. (2004). "O financiamento do município de Belém". In: CARVALHO, Guilherme et al. (orgs.). Políticas públicas e gestão local: programa de capacitação em políticas de desenvolvimento urbano sustentável e gestão democrática. Belém: Fase.

GENRO, Tarso et al. (1997). Desafios do governo local: o modo petista de governar. São Paulo: Editora Fundação Perseu Abramo. 
; (2001). Instituições políticas no socialismo. São Paulo: Editora Fundação Perseu Abramo. (Coleção Socialismo em Discussão).

; SOUZA, Ubiratan. (1997). Orçamento Participativo: a experiência de Porto Alegre. São Paulo: Editora Fundação Perseu Abramo.

GRAMSCI, Antonio. (1995). Concepção dialética da história. Rio de Janeiro: Civilização Brasileira. 10 ${ }^{\underline{a}}$ ed.

SILVA NETO, João Gomes; MALATO, Olinda (orgs). (2004). Caminhos da participação popular na democratização do orçamento público em Belém. Belém: Fase.

LEITE, Marcus Vinnicius. (2010). “Imagens da Amazônia paraense: uma leitura alegórica da obra de Dalcídio Jurandir". In: SIMONIANIAN, Ligia. (org.). Belém do Pará: História, cultura e sociedade. Belém: Editora do NAEA.

LIMA, Leandro Mahalem de. (2008). Rios vermelhos: perspectivas e posições de sujeitos em torno da noção de cabano na Amazônia em meados de 1835. 301p. Dissertação de mestrado em antropologia social. São Paulo: FFLCH-USP.

LIMA, Nísia Trindade. (2009). "Euclides da Cunha: o Brasil como sertão”. In: BOTELHO, André, SCHWARCZ, Lilia. Um enigma chamado Brasil: 29 intérpretes e um país. São Paulo: Companhia das Letras.

. (2011). "Campo e cidade: veredas do Brasil moderno". In: BOTELHO, André; SCHWARCZ, Lilia. Agenda brasileira: temas de uma sociedade em mudança. São Paulo: Companhia das Letras.

LIRA, José Tavares Correia de. (2005). “Naufrágio e galanteio: viagem, cultura e cidades em Mário de Andrade e Gilberto Freyre”. Revista Brasileira de Ciências Sociais, v.20, no․ 57, pp. 143-176.

MALATO, Olinda Rodrigues. (2006). Democratização e gestão pública na Amazônia: do Orçamento Participativo ao Congresso da Cidade no município de Belém-PA (19972004). 270p. Tese de doutorado em serviço social. Rio de Janeiro: ESS-UFRJ.

MARTINS, Maria Lucia Refinetti. (2000). Os desafios da gestão municipal democrática Belém 1997-2000: desenhando a cidade do terceiro milênio. São Paulo: Pólis.

___ (s/d) "Planejamento estratégico participativo numa capital amazônica: a experiência de Belém do Pará”. Disponível em 
$<$ http://www.usp.br/fau/depprojeto/labhab/biblioteca/textos/martins_planejament obelem.pdf>.

MARQUES, Fernando Luiz Tavares. (2010). "Um sítio indígena sob a Feliz Lusitânia: descobertas recentes em arqueologia urbana, em Belém do Pará". In: SIMONIANIAN, Ligia. (org.). Belém do Pará: História, cultura e sociedade. Belém: Editora do NAEA.

MIAGUSKO, Edson. (2001). Greve dos petroleiros de 1995: a construção democrática em questão. 134p. Dissertação de mestrado em sociologia. São Paulo: FFLCH-USP.

__. (2012). Movimentos de moradia e sem-teto em São Paulo. São Paulo: Alameda.

MOTA, Lourenço. (2002). Introdução ao Brasil. Um banquete no trópico, 2. São Paulo: Editora SENAC.

NAKANO, Anderson Kazuo. (2011).“Desenvolvimento urbano e territorial em municípios periurbanos, diferenciações no universo dos municípios brasileiros". In: Os municípios periurbanos e o direito à cidade: uma agenda em construção. Belém: Fase.

NOVA CARTOGRAFIA SOCIAL DA AMAZÔNIA. Afro-religiosos na cidade de Belém. Belém: INTECAB-PA; UFPA; Iagua; Iara, n.3. 12p. Série Movimentos Sociais e Conflitos nas Cidades da Amazônia.

. Catadores na cidade de Belém. Belém: Movimento dos Catadores de Belé; UFPA; Iagua; Iara, n.5. 12p. Série Movimentos Sociais e Conflitos nas Cidades da Amazônia. . Homoxessuais na cidade de Belém. Belém: Movimento GLTB do Pará; UFPA; Iagua; Iara, n.2. 12p. Série Movimentos Sociais e Conflitos nas Cidades da Amazônia. . [2005]. Indígenas na cidade de Belém. Belém: AIAMB; UFPA; Iagua; Iara, n.1. 12p. Série Movimentos Sociais e Conflitos nas Cidades da Amazônia.

. Negras e Negros na cidade de Belém. Belém: Setorial de Negras e Negros do Estado do Pará; UFPA; Iagua; Iara, n.4. 12p. Série Movimentos Sociais e Conflitos nas Cidades da Amazônia.

. Pessoas com Deficiência na cidade de Belém. Belém: Movimento das Pessoas com Deficiência de Belém; UFPA; Iagua; Iara, n.2. 12p. Série Movimentos Sociais e Conflitos nas Cidades da Amazônia. - (2008). Moradores do Riacho Doce e Pantanal: História de luta e conquista do Igarapé de Tucunduba - Belém. Belém: Movimento GLTB do Pará; UFPA; Iagua; Iara, n.2. 12p. Série Movimentos Sociais e Conflitos nas Cidades da Amazônia. 
. (2009). Nossas vidas, nossos direitos: Portal da Amazônia. Manaus: UEA Edições / PPGAS-UFAM. Boletim informativo - Nova Cartografia Social, Ano 2, no 3. 16p.

NOVAES, Jurandir; MATOS, Lucília; WAGNER, Alfredo (coord.). (2003). Belém de todas as falas: testemunhos, relatos e atos do Congresso da Cidade. Belém: Vanguarda.

NUNES, Brasilmar Ferreira. (2008). "A interface entre o urbano e o rural na Amazônia brasileira". In: CASTRO, Edna. (org.). Cidades na floresta. São Paulo: Annablume.

OLIVEIRA, Francisco de. (1994). "A reconquista da Amazônia". Novos Estudos CEBRAP, n. 38, pp.3-14, mar.

. (1998). Os direitos do antivalor: a economia política da hegemonia imperfeita. Petrópolis: Vozes, 1998.

- (1999). "Privatização do público, destituição da fala e anulação da política: o totalitarismo neoliberal." In: OLIVEIRA, F.; PAOLI, M.C. (org). Os sentidos da democracia. Petrópolis: Vozes.

. (2000). "Paisagem na neblina" In: et al. Classes sociais em mudança e a luta pelo socialismo. São Paulo: Ed. Fundação Perseu Abramo, 2000.

. (2001). "Como pensar com radicalidade e especificidade". Lua Nova, n.54, pp.89-95. (2003a). "Democratização e republicanização do Estado". Disponível em $<$ http://www.fpabramo.org.br/o-que-fazemos/editora/teoria-e-debate/edicoesanteriores/ensaio-democratizacao-e-republicanizacao-do>.

. (2003b). Crítica à razão dualista: o ornitorrinco. São Paulo: Boitempo. . (2008). A noiva da revolução; Elegia para uma re(li)gião: Sudene, Nordeste.

Planejamento e conflitos de classes. São Paulo: Boitempo.

(2002). "Nacional: Adeus às oligarquias?" Disponível em $<$ http://www.fpabramo.org.br/o-que-fazemos/editora/teoria-e-debate/edicoesanteriores/nacional-adeus-oligarquias> ; RIZEK, Cibele Saliba. (2007). A era da indeterminação. São Paulo: Boitempo. ;____; PAOLI, Maria Celia. (2003). "Atas da Revolução: O Orçamento participativo em São Paulo" Democracia Viva, Rio de Janeiro: Ibase.

OLIVEIRA VIANNA, Francisco José de. (1987). Populações Meridionais do Brasil: populações rurais do Centro-sul. São Paulo: Itatiaia, v.1. 
PARACAMPO, Maria Vitória. (1992). Cidadania e direito de mora: a prática de ocupações coletivas e o movimento de posseiros. 380p. Dissertação de mestrado em planejamento do desenvolvimento. Belém: NAEA-UFPA.

PAOLI, Maria Célia. (1987). "Os trabalhadores urbanos na fala dos outros”. In: LOPES, José Sérgio Leite. (coord.). Cultura e identidade operária. Rio de Janeiro: Marco Zero; Ed. da UFRJ.

. (2002). "Habitar a cidade de São Paulo: experiências e julgamentos". Relatório parcial (2001-2002) para projeto temático do Cenedic para Fapesp. São Paulo. (mimeo)

. (2003). “Movimentos sociais, movimentos republicanos?” In: SILVA, Fernando et al. (org). República, liberalismo, cidadania. Piracicaba: Ed. Unimep.

. (2007). "O mundo do indistinto: sobre gestão, violência e política" In: OLIVEIRA, Francisco de; RIZEK, Cibele Saliba. A era da indeterminação. São Paulo: Boitempo.

; SADER, Eder. (1986). “Sobre 'classes populares' no pensamento sociológico brasileiro". In: CARDOSO, Ruth (org.). A aventura antropológica. Rio de Janeiro: Editora Paz e Terra.

PETIT, Pere. (1996). A esperança equilibrista: a trajetória do PT no Pará. São Paulo: Boitempo.

PEREIRA, Dalcídio Jurandir Ramos. (2004). Belém do Grão Pará. Belém: Edufpa/ Casa de Rui Barbosa.

PEREIRA DE QUEIROZ, Maria Izaura. (1976). O mandonismo local na vida política brasileira e outros ensaios. São Paulo, Ed. Alfa-Omega.

PRESSLER, Neusa. (2010). “Econegócios e cooperação internacional: novos discursos sobre a Amazônia".

PINHEIRO, Andréa Pinheiro et al. (2007). “A questão habitacional na Região Metropolitana de Belém." In: CARDOSO, Adauto (org.). Habitação social nas metrópoles brasileiras: uma avaliação das políticas habitacionais em Belém, Belo Horizonte, Porto Alegre, Recife, Rio de Janeiro e São Paulo no final do século XX. Porto Alegre: Antac.

PORTELA, Roselene de Souza. 2005. Planejamento, participação popular e gestão de políticas urbanas: a experiência do projeto de macrodrenagem da Bacia do Una (Belém-PA). Disponível em <http://www.ufpa.br/naea/gerencia/ler_tcc.php?id=72> 
RANCIÈRE, Jacques. (1988). A Noite dos Proletários. São Paulo: Companhia das Letras. . (1995). Políticas da escrita. Rio de Janeiro: Editora 34.

. (1996). O desentendimento. São Paulo: Editora 34.

(2005). La haine de la démocratie. Paris: La Fabrique.

RIBEIR0, Ana Clara; GRAZIA, Grazia. (2003). Experiências de Orçamento Participativo no Brasil - Período 1997 a 2000. Rio de Janeiro: Vozes.

RIBEIRO, Frank de Paula. (2001). Cidadania possível ou clientelismo urbano? Política e cultura no orçamento participativo da habitação em Belo Horizonte (1995-2000). Dissertação de mestrado em administração pública. Belo Horizonte: Escola de Governo Professor Paulo Neves de Carvalho/ Fundação João Pinheiro.

RICCI, Magda. (2007). “Cabanagem, cidadania e identidade revolucionária: o problema do patriotismo na Amazônia entre 1835 e 1840.” Tempo [online]. 2007, v.11, n.22, pp. 530. Disponível em <http://www.scielo.br/pdf/tem/v11n22/v11n22a02.pdf>

RICUPERO, Bernardo. (2007). Sete lições sobre as interpretações do Brasil. São Paulo: Editora Alameda.

. (2008). “Da formação à forma. Ainda as 'ideias fora do lugar'”. Lua Nova, São Paulo, n.73, pp. 59-69.

RIZEK, Cibele Saliba. (2007). "São Paulo: orçamento e participação". In: ; OLIVEIRA, Francisco. (org.). A era da indeterminação. São Paulo: Boitempo. . (2002). "Os sentidos da cidade na sociologia brasileira: da civilidade ao seu avesso". Relatório parcial (2001-2002) para projeto temático do Cenedic para Fapesp. São Paulo. (mimeo)

RODRIGUES, Edmilson; NOVAES, Jurandir Santos (orgs.). (2002). Luzes na floresta: o governo democrático e popular em Belém (1997-20001). Belém: Prefeitura Municipal de Belém.

; ____ ARAÚJO, Raimundo Luiz da S. (2002). Congresso da Cidade: construir o poder popular reinventando o futuro. Belém: Labor Editorial.

ROMÃO, Wagner de Melo. (2011). “Conselheiros do Orçamento Participativo nas franjas da sociedade política”. Lua Nova, São Paulo, no 84, pp. 219-244.

SADER, Eder. (1988). Quando novos personagens entram em cena. Rio de Janeiro: Editora Paz e Terra. 
SANTOS, Laymert Garcia dos. (2003). Politizar as novas tecnologias: o impacto sócio-técnico da informação digital e genética. São Paulo: Editora 34.

SCHWARCZ, Lilia; BOTELHO, André. (2008). "Ao vencedor as batatas 30 anos: crítica da cultura e processo social: entrevista com Roberto Schwarz". Revista Brasileira de Ciências Sociais, v.23, n.67, pp.147-160.

SCHWARZ, Roberto. (1992). Ao vencedor as batatas. São Paulo, Duas Cidades. . (1990). Um mestre na periferia do capitalismo. São Paulo: Duas Cidades. . (1997). Duas meninas. São Paulo: Companhia das Letras. . (1999). Sequências brasileiras. São Paulo: Companhia das Letras. . (2006). "Leituras em competição". Novos estudos Cebrap, n. 75.

SEGEP. FUNPAPA. (2000). Formas de apropriação e uso do território. Belém. (Coleção Mapas de Belém, 1).

SILVA, Sebastião Carlos de Aquino. (2006). Participação no Orçamento da Gestão Municipal de 1997 a 2000 em Belém do Pará: democratização das relações entre governantes e governados. 197 p. Tese de doutorado em serviço social. Rio de Janeiro: ESS-UFRJ.

SIMONIANIAN, Ligia. (2010). "Indígenas de e em Belém: história, cultura e condições atuais". In: SIMONIANIAN, Ligia. (org.). Belém do Pará: História, cultura e sociedade. Belém: Editora do NAEA.

SOUZA, Jessé. A modernização seletiva: uma reinterpretação do dilema brasileiro. Brasília: Editora Universidade de Brasília, 2000.

SOUZA FILHO, Benedito. (2009). "Identidade e território: a "guerra" como instrumento de expropriação". In: FERRETI, Sérgio; RAMALHO, José Ricardo (orgs.). Amazônia: desenvolvimento, meio ambiente e diversidade. São Luis: Edufma.

SPOSATI, Aldaíza. (1988). Vida urbana e gestão da pobreza. São Paulo: Editora Cortez.

TEIXEIRA, Ana Claudia; ALBUQUERQUE, Maria do Carmo. (2006). "Orçamentos Participativos: projetos políticos, partilha de poder e alcance democrático". In: DAGNINO, Evelina; OLVERA, Alberto Rivera; PANFICHI, Aldo (orgs.). A disputa pela construção democrática na América Latina. São Paulo: Paz e Terra; Ed. da Unicamp.

TEIXEIRA, Ana Claudia. (s/d). O orçamento participativo em pequenos municípios rurais: contextos, condições de implementação e formatos da experiência. Disponível em 
<http://www.democraciaparticipativa.org/files/AnaClaudiaOor\%E7amentoparticipat ivoempequenosmunic\%EDpiosrurais.pdf>

TELLES, Vera da Silva. (1999). "Pobreza e cidadania: figurações da questão social no Brasil moderno" in Direitos Sociais: Afinal de que se trata? Belo Horizonte, Ed. da UFMG.

. (2001). Pobreza e cidadania. São Paulo: Editora 34; Edusp.

THOMPSON, E. P. (1998). Costumes em comum. São Paulo: Cia das Letras.

. (1984). "La sociedad inglesa del siglo XVIII: lucha de clases sin clases?" In:

Tradición, revuelta y conciencia de clase. Barcelona: Editorial Crítica, 1984.

TRINDADE Jr., Saint-Clair et al. (orgs.). (2009). Pequenas e Médias cidades na Amazônia. Belém: FASE.

VELHO, Otávio Guilherme. (2009) Frentes de expansão e estrutura agrária: estudo do processo de penetração numa área da Transamazônica. Rio de Janeiro: Centro Edelstein de Pesquisas Sociais. $3^{\underline{a}}$ ed. (1ํㅡㄹ ed. virtual)

WERNECK VIANNA, Luiz. (1988). Vantagens do moderno, vantagens do atraso. Presença Revista de Cultura e Política. n. 12. p.146-162

. (1993). A Revolução Passiva: Iberismo e Americanismo no Brasil. Rio de Janeiro:

Editora Revan/IUPERJ.

. (1999). "Weber e a interpretação do Brasil". Novos Estudos CEBRAP, no 53, pp. 33-47. . (2009). "Raymundo Faoro e a difícil busca do moderno no país da modernização". In: BOTELHO, André; SCHWARCZ, Lília. Um enigma chamado Brasil: 29 intérpretes e um país. São Paulo: Companhia das Letras.

\section{Documentos impressos consultados ${ }^{1}$}

3‥ Congresso da Cidade: o povo decide, a prefeitura faz. Caderno de teses e obras aprovadas. Belém, 2003.

Cadernos de Teses para o I Congresso Municipal de Educação. Belém, 2003.

Cadernos dos Regimentos do Congresso da Cidade 2004. Belém, 2004.

\footnotetext{
${ }^{1}$ Todos documentos citados aqui são impressos. O arquivo digital com documentos referentes ao OP e ao Congresso da Cidade, obtido por intermédio de Marly Brito e José Carlos Pereira, não foi catalogado dado seu volume que se aproximava de quatrocentos arquivos.
} 
Começa o Congresso da Cidade 2002. Em Belém, é assim que se faz. Folheto. Belém, 2002.

Conferência de Juventude. Programa de Governo. Belém, junho de 2001.

Congresso da Cidade 2002. Em Belém, é assim que se faz. Cartilha. Belém, 2002.

PMB; Gestão Venturi Consultoria. Orçamento Participativo - Estudo junto aos representantes da população no Fórum Municipal: Perfil e avaliação. Relatório de pesquisa, Belém, setembro de 1998.

. Orçamento Participativo - Estudo junto aos representantes da população no Fórum Municipal: Perfil e avaliação. Relatorio de pesquisa, Belém, setembro de 1998.

Critérios Técnicos OP 2000. Folheto. Belém, Janeiro de 2000.

I Congresso Geral da Cidade de Belém. Documento base do Congresso da Cidade. Belém, 2001.

Orçamento participativo. Belém construindo o poder popular. Folheto de funcionamento. Belém, 1997.

FRENTE BELÉM POPULAR. Programa de governo. Belém, agosto 1996. . O próximo passo: qualidade de vida por uma Belém crianças. Diretrizes porgramáticas da Frente Belém Popular, 200/2004. Belém, 2000.

Plano Belém 400 Anos: uma proposta para o debate. Belém, junho de 2004.

PMB. Mensagem da Prefeitura de Belém à Câmara Municipal. Relatório de Atividades do exercício de 2001. Belém, 2002. . As administrações regionais no Governo do Povo: tópicos para reflexão. Belém, 1998.

PMB. SEGEP - Departamento de Pesquisa e Informação. Memória do Congresso da Cidade, 1998-2004. Belém, 2004.

PMB. SEGEP - Coordenadoria de Relações com a Comunidade. Orçamento Participativo. Belém construindo o poder popular. 1997. Folheto. Belém, 1998.

PMB. SEGEP - GT Congresso da Cidade; Gestão Venturi Consultoria. Pesquisa qualitativa: $O$ Congresso da Cidade, Identidade, diagnóstico e vocação de Belém. Relatório de pesquisa. Belém, agosto de 1999.

PMB. SEGEP. Caixa de sugestões do Congresso da Cidade. Relatório. Belém, [2001]. . Situação atual do projeto de recuperação da Bacia do Una. Belém, maio de 1997. . I Congresso Municipal de Financiamento e Desenvolvimento Econômico. Textos para debate. Belém, junho de 2003. 
Regimento Interno do COP. Belém, [1999].

\section{Entrevistas da pesquisa}

ARAÚJO Jr., Aldenor. Entrevista concedida à pesquisadora, em 02 de dezembro de 2009. BARBOSA, Inês. Entrevista concedida à pesquisadora, em 08 de dezembro de 2009.

BRITO, Marinor. Entrevista concedida à pesquisadora, em 31 de julho de 2009.

CARDOSO, Waldir. Entrevista concedida à pesquisadora, em 09 de dezembro de 2009.

CARMO, Rui do. Entrevista concedida à pesquisadora, em agosto de 2009.

CAVALERA, Pedro. Entrevista concedida à pesquisadora, em agosto de 2009.

CLEIDISSON. Entrevista concedida à pesquisadora, em maio de 2007.

CRUZ, Sandra Helena. Entrevista concedida à pesquisadora, em 04 de dezembro de 2009.

ELOY. Entrevista concedida à pesquisadora, em 20 de agosto de 2011.

FERNANDES, Omar. Entrevista concedida à pesquisadora, em 31 de julho de 2009.

FREIRE, Clóvis. Entrevista concedida à pesquisadora, em 06 de agosto de 2009.

GOMES, João; CARVALHO, Guilherme. Entrevista concedida à pesquisadora, em 04 de dezembro de 2009.

GUSMÃO, Renato. Entrevista concedida à pesquisadora, em agosto de 2009.

ISABEL. Entrevista concedida à pesquisadora, em maio de 2007.

KABÁ, Emílio. Entrevista concedida à pesquisadora, em 04 de agosto de 2009.

MARACAJÁ, Célia. Entrevista concedida à pesquisadora, em 03 de dezembro de 2009.

MENEZES, Levy. Entrevista concedida à pesquisadora, em maio de 2007.

MORAES, Lázaro. Entrevista concedida à pesquisadora, em 23 de agosto de 2011.

OTTERLO0, Aldalice Moura da Cruz. Entrevista concedida à pesquisadora, em 03 de dezembro de 2009.

Pai ALBERTO. Entrevista concedida à pesquisadora, em maio de 2007.

PAULA, Domingas de. Entrevista concedida à pesquisadora, em 07 de dezembro de 2009.

RIBEIRO, Rita de Cássia. Entrevista concedida à pesquisadora, em 04 de agosto de 2009.

RODRIGUES, Edmilson. Entrevista concedida à pesquisadora, em setembro de 2005.

SANTOS, Stefani Henrique. Entrevista concedida à pesquisadora, em 31 de julho de 2009.

SOCORRO. Entrevista concedida à pesquisadora, em maio de 2007. 